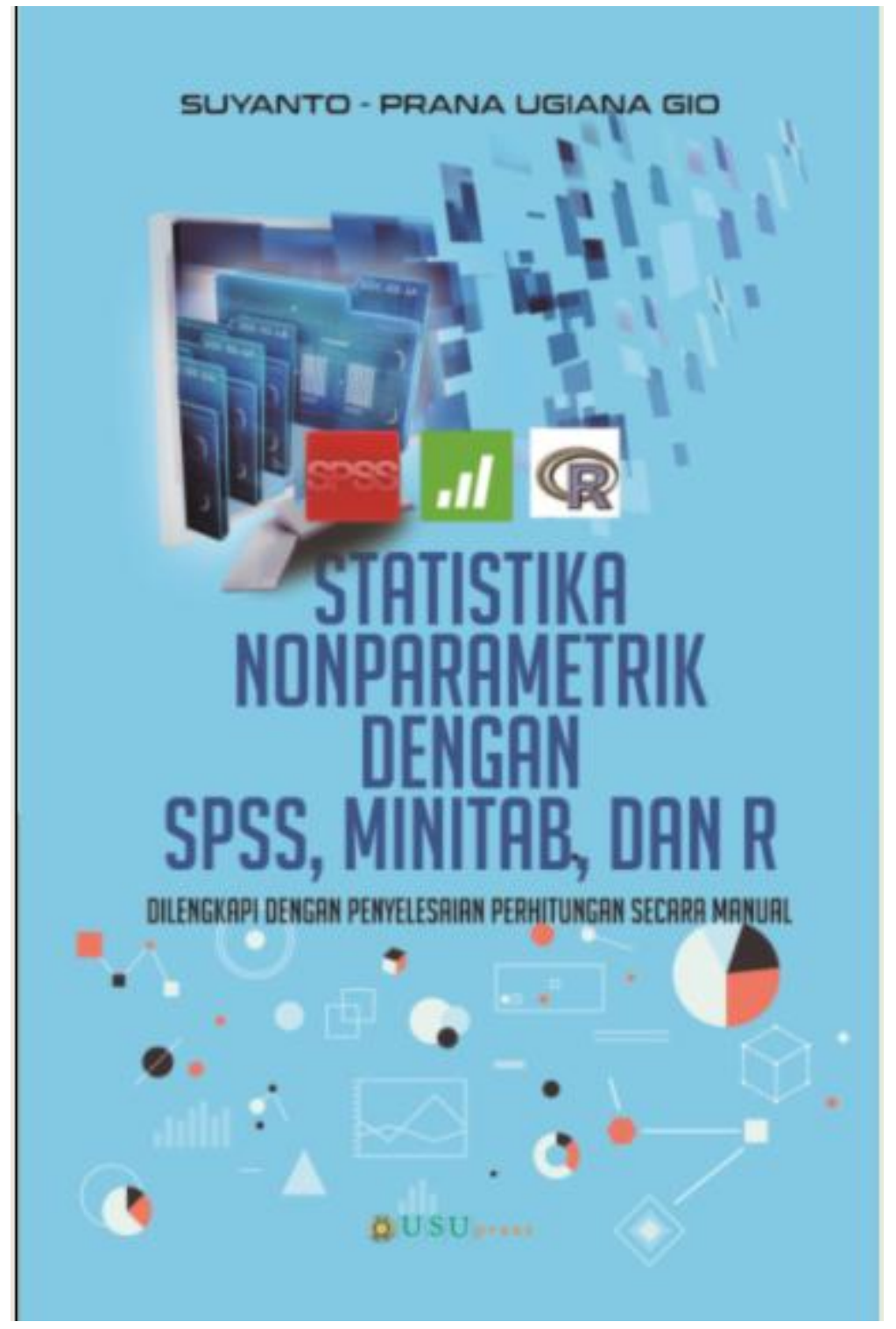




\section{Statistika Nonparametrik dengan SPSS, Minitab, dan R}

Dilengkapi dengan Penyelesaian Perhitungan secara

Manual

\section{SUYANTO}

\&

\section{PRANA UGIANA GIO}

U U S Upress 



\section{USU Press}

Art Design, Publishing \& Printing

Gedung F

Jl. Universitas No. 9, Kampus USU

Medan, Indonesia

Telp. 061-8213737; Fax 061-8213737

Kunjungi kami di:

http://usupress.usu.ac.id

(C) USUpress 2017

Hak cipta dilindungi oleh undang-undang; dilarang memperbanyak, menyalin, merekam sebagian atau seluruh bagian buku ini dalam bahasa atau bentuk apapun tanpa izin tertulis dari penerbit.

ISBN: 978-602-465-010-0

Perpustakaan Nasional: Katalog Dalam Terbitan (KDT)

Suyanto dan Prana Ugiana Gio

Aplikasi Statistika dalam SPSS : Dilengkapi dengan Penyelesaian Secara Manual dan Contoh Soal / Suyanto dan Prana Ugiana Gio - Medan: USU Press. 2017

iv, 137 p. ; ilus. ; $20 \mathrm{~cm}$

Bibliografi

ISBN: 978-602-465-010-0

Dicetak di Medan, Indonesia 


\section{KATA PENGANTAR}

Alhamdulillah, puji syukur atas kehadirat Allah SWT, karena atas izinNya, penulis dapat terus mempertahankan semangat untuk menulis, dan akhirnya dapat menyelesaikan buku ini. Hadirnya buku ini, tidak semata-mata atas usaha penulis sendiri, melainkan atas izin-Nya. Sungguh suatu kebahagiaan bagi penulis bisa berbagi sebagian kecil ilmu pengetahuan milik-Nya melalui buku yang berjudul "Statistika Nonparametrik dengan SPSS, Minitab, dan R".

Ucapan terima kasih penulis sampaikan kepada semua pihak yang telah membantu dalam rangkapenyelesaian buku ini. Penulis menyadari bahwa buku ini tentunya masih perlu perbaikan, sehinggapenulis mengharapkan kritik dan saran yang membangun dari para pembaca agar buku ini dapatmenjadi lebih baik. Kritik dan saran dapat ditujukan ke alamat emailsuyantonurdin@yahoo.com/gioprana89@gmail.com.

Medan, 25September 2017

Suyanto

Prana Ugiana Gio 


\section{DAFTAR ISI}

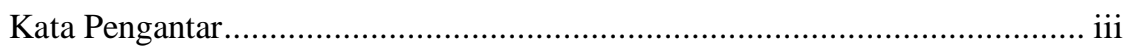

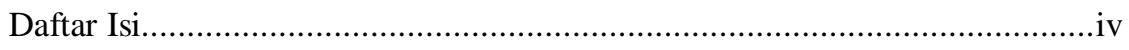

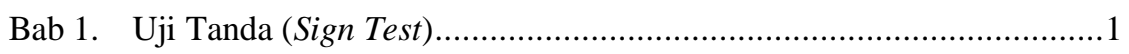

Bab 2. Uji Wilcoxon .......................................................................

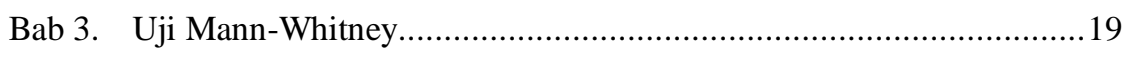

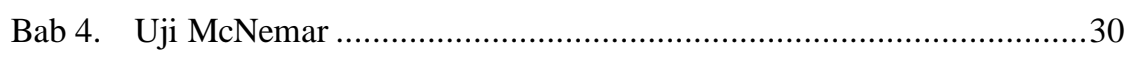

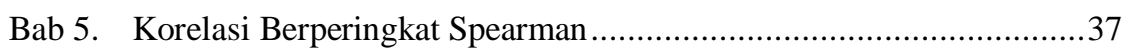

Bab 6. Uji Kruskal-Wallis......................................................... 42

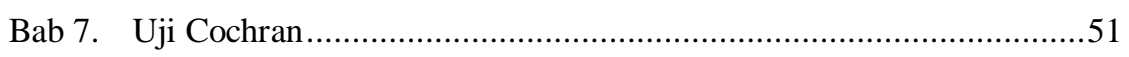

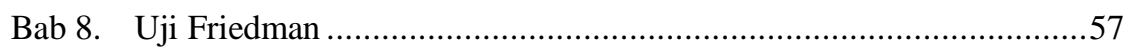

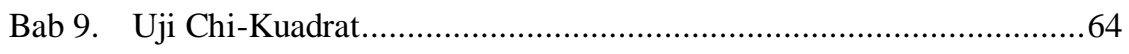

Bab 10. Penyelesaian dengan SPSS, Minitab, dan R..................................73

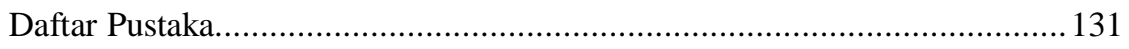




\section{UJI TANDA (SIGN TEST)}

Uji tanda merupakan uji nonparametrik yang digunakan untuk menguji ada tidaknya perbedaan dari dua buah populasi yang saling berpasangan. Misalkan diberikan data mengenai berat badan sebelum mengkonsumsi obat penambah berat badan merek $X Y Z$ dan sesudah mengkonsumsi obat penambah berat badan merek $X Y Z$ selama satu minggu.

\section{Tabel 1.1 (Data Fiktif)}

\begin{tabular}{|c|c|c|c|c|c|c|c|c|c|}
\hline Nama & A & B & C & D & E & F & G & H & I \\
\hline$P$ & $45 \mathrm{~kg}$ & $50 \mathrm{~kg}$ & $35 \mathrm{~kg}$ & $45 \mathrm{~kg}$ & $54 \mathrm{~kg}$ & $44 \mathrm{~kg}$ & $41 \mathrm{~kg}$ & $44 \mathrm{~kg}$ & $35 \mathrm{~kg}$ \\
\hline$Q$ & $44 \mathrm{~kg}$ & $50 \mathrm{~kg}$ & $37 \mathrm{~kg}$ & $50 \mathrm{~kg}$ & $57 \mathrm{~kg}$ & $48 \mathrm{~kg}$ & $45 \mathrm{~kg}$ & $44 \mathrm{~kg}$ & $35 \mathrm{~kg}$ \\
\hline Tanda & - & 0 & + & + & + & + & + & 0 & 0 \\
\hline
\end{tabular}

Berdasarkan data pada Tabel 1.1, misalkan $P$ menyatakan sampel mengenai data berat badan sebelum mengkonsumsi obat penambah berat badan merek $X Y Z$, sedangkan $Q$ menyatakan sampel mengenai data berat badan setelah mengkonsumsi obat penambah berat badan merek $X Y Z$ selama satu minggu. Berdasarkan data pada Tabel 1.1, jumlah responden yang diteliti sebanyak 9 responden. Perhatikan bahwa $(45,44),(50,50)$, $(35,37)$, dan seterusnya merupakan pasangan-pasangan nilai berdasarkan sampel $P$ dan sampel $Q$. 
Seorang yang bernama $A$ sebelum mengkonsumsi obat penambah berat badan merek $X Y Z$ memiliki berat badan $45 \mathrm{~kg}$ dan setelah mengkonsumsi obat penambah berat badan merek $X Y Z$ selama satu minggu memiliki berat badan $44 \mathrm{~kg}$, yang dinyatakan dengan $(45,44)$. Seorang yang bernama $B$ sebelum mengkonsumsi obat penambah berat badan merek $X Y Z$ memiliki berat badan $50 \mathrm{~kg}$ dan setelah mengkonsumsi obat penambah berat badan merek $X Y Z$ selama satu minggu memiliki berat badan $50 \mathrm{~kg}$ yang dinyatakan dengan $(50,50)$, dan seterusnya.

Pada uji tanda, jika selisih dari pasangan nilai data bernilai positif $(Q>P)$, maka diberi tanda positif $(+)$. Berdasarkan data pada Tabel 1.1, tanda positif (+) diberikan kepada C, D, E, F, dan G. Jika selisih dari pasangan nilai data bernilai negatif $(Q<P)$, maka diberi tanda negatif $(-)$. Berdasarkan data pada Tabel 1.1, tanda negatif (-) diberikan kepada A. Namun jika selisih dari pasangan nilai data bernilai $0(Q=P)$, maka diberi nilai 0 . Berdasarkan data pada Tabel 1.1, nilai 0 diberikan kepada B, H, dan I.

Data dalam uji tanda bersifat ordinal, yakni data yang dianalisis pada uji tanda berupa tanda positif $(+)$ dan tanda negatif $(-)$, sedangkan nilai 0 tidak diikutsertakan dalam analisis. Nilai 0 berarti tidak terdapat perubahan sebelum dan sesudah perlakuan. Misalkan $n$ menyatakan jumlah tanda positif $(+)$ dan tanda negatif $(-)$. Berdasarkan data pada Tabel 1.1, jumlah tanda positif 
(+) sebanyak 5, sedangkan jumlah tanda negatif $(-)$ sebanyak 1 , sehingga nilai $n$ adalah $5+1=6$.

Misalkan $X$ menyatakan jumlah tanda yang paling sedikit, yakni antara jumlah tanda positif $(+)$ atau jumlah tanda negatif $(-)$. Berdasarkan data pada Tabel 1.1, diketahui jumlah tanda positif (+) sebanyak 5, sedangkan jumlah tanda negatif (-) sebanyak 1 , sehingga nilai $X$ adalah 1.Hipotesis nol yang diuji pada uji tanda pada dasarnya menyatakan tidak dapat pengaruh sebelum dan sesudah perlakuan. Dengan kata lain, probabilitas untuk memperoleh tanda positif $(+)$ sama dengan probabilitas untuk memperoleh tanda negatif $(-)$, yakni

$$
H_{0}: P(+)=P(-)
$$

Hipotesis alternatif menyatakan terdapat pengaruh sebelum dan sesudah perlakuan (dalam hal ini uji dua arah). Dengan kata lain, probabilitas untuk memperoleh tanda positif $(+)$ tidak sama dengan probabilitas untuk memperoleh tanda negatif $(-)$, yakni

$$
H_{1}: P(+)=P(-)
$$

Untuk pengambilan keputusan terhadap hipotesis, perlu dihitung nilai probabilitas kumulatif ( $p$-value) dari nilai $X$. Jika dilakukan pengujian hipotesis dua arah (terdapat dua daerah penolakan hipotesis nol), maka rumus untuk menghitung nilai pobabilitas kumulatif dari nilai $X$ adalah 


$$
2\left[\sum_{i=0}^{X}\left(\begin{array}{c}
n \\
i
\end{array}\right)\left(\frac{1}{2}\right)^{i}\left(\frac{1}{2}\right)^{n-i}\right]
$$

Jika dilakukan pengujian hipotesis satu arah (terdapat satu daerah penolakan hipotesis nol), maka rumus untuk menghitung nilai pobabilitas kumulatif dari nilai $X$ adalah

$$
\sum_{i=0}^{X}\left(\begin{array}{c}
n \\
i
\end{array}\right)\left(\frac{1}{2}\right)^{i}\left(\frac{1}{2}\right)^{n-i}
$$

Jika nilai probabilitas kumulatif dari nilai $X$ lebih besar atau sama dengan tingkat signifikansi $(\alpha)$, maka hipotesis nol diterima dan hipotesis alternatif ditolak. Namun jika nilai probabilitas kumulatif dari nilai $X$ lebih kecil dibandingkan tingkat signifikansi $(\alpha)$, maka hipotesis nol ditolak dan hipotesis alternatif diterima.

Jika nilai probabilitas kumulatif dari $X(p-$ value $)$ $\geq \alpha, H_{0}$ diterima, $H_{1}$ ditolak.

Jika nilai probabilitas kumulatif dari $X(p-$ value $)$ $<\alpha, H_{0}$ ditolak, $H_{1}$ diterima.

Tabel 1.2 menyajikan nilai probabilitas kumulatif.

Tabel 1.2

Test Statistics ${ }^{b}$

\begin{tabular}{|l|c|}
\hline & $\begin{array}{c}\text { sesudah }- \\
\text { sebelum }\end{array}$ \\
\hline Exact Sig. (2-tailed) & $.013^{\mathrm{a}}$ \\
\hline
\end{tabular}

a. Binomial distribution used.

b. Sign Test
"2-Tailed" berarti pengujian hipotesis berlaku dua arah. Nilai 0,013 merupakan nilai probabilitas kumulatif yang dihitung berdasarkan rumus binomial. 
Sebagai contoh misalkan seorang ahli farmasi ingin mengetahui ada tidaknya pengaruh terhadap perubahan berat badan sebelum mengkonsumsi obat penambah berat badan merek XYZ dan sesudah mengkonsumsi obat penambah berat badan merek XYZ selama satu minggu.

\section{Tabel 1.3 (Data Fiktif)}

\begin{tabular}{|c|c|c|c|c|c|c|c|c|c|c|c|c|c|c|c|}
\hline Vlama & A & $B$ & C & D & 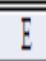 & F & $\theta$ & $\mathbb{H}$ & 1 & $\mathrm{j}$ & $\mathbb{K}$ & L & N & 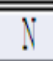 & 0 \\
\hline$X$ & 45 & 35 & 57 & it & 65 & 72 & 80 & 4 & 67 & 60 & 65 & 75 & 67 & 66 & 62 \\
\hline$y$ & 50 & 60 & 60 & 65 & 63 & 80 & 90 & 50 & 65 & 60 & 75 & 80 & 85 & 70 & 65 \\
\hline
\end{tabular}

Misalkan $X$ menyatakan berat badan sebelum mengkonsumsi obat penambah berat badan merek $X Y Z$, sedangkan $Y$ menyatakan berat badan sesudah mengkonsumsi obat penambah berat badan merek $X Y Z$ selama satu minggu. Dengan menggunakan tingkat signifikansi $5 \%$, berikut akan diuji apakah terdapat perbedaan berat badan yang signifikan secara statistika, sebelum mengkonsumsi obat penambah berat badan merek $X Y Z$ dan sesudah mengkonsumsi obat penambah berat badan merek $X Y Z$ selama satu minggu.

\section{Tahap Pertama}

Tahap pertama adalah perumusan hipotesis. Berikut perumusan hipotesis.

$H_{0}$ : Tidak terdapat perbedaan berat badan sebelum mengkonsumsi obat penambah berat badan merek $A$ dan sesudah 
mengkonsumsi obat penambah berat badan merek $A$ selama satu minggu atau dapat dinyatakan $P(+)=P(-)$.

$H_{1}$ : Terdapat perbedaan berat badan sebelum mengkonsumsi obat penambah berat badan merek $A$ dan sesudah mengkonsumsi obat penambah berat badan merek $A$ selama satu minggu atau dapat dinyatakan $P(+) \neq P(-)$.

\section{Tahap Kedua}

Tahap kedua adalah menentukan tingkat signifikansi yang nantinya akan dibandingkan dengan nilai probabilitas kumulatif dari nilai $X$. Tingkat signifikansi yang digunakan dalam kasus ini adalah $\alpha=5 \%$ atau $\alpha=0,05$.

\section{Tahap Ketiga}

Tahap ketiga adalah menghitung nilai probabilitas kumulatif dari nilai $X$.

Tabel 1.4

\begin{tabular}{|c|c|c|c|c|c|c|c|c|c|c|c|c|c|c|c|}
\hline Nama & A & $B$ & $C$ & D & E & F & G & H & I & J & K & L & M & N & O \\
\hline$X$ & 45 & 55 & 57 & 54 & 65 & 72 & 80 & 44 & 67 & 60 & 65 & 75 & 67 & 66 & 62 \\
\hline Y & 50 & 60 & 60 & 65 & 63 & 80 & 90 & 50 & 65 & 60 & 75 & 80 & 85 & 70 & 65 \\
\hline Tanda & + & + & + & + & - & + & + & + & - & 0 & + & + & + & + & + \\
\hline
\end{tabular}

$\Rightarrow$ Pertama akan ditentukan tanda untuk setiap pasangan nilai data. Berdasarkan data pada Tabel 1.4, pasangan nilai data $(45,50)$ diberi tanda positif $(+)$ karena $50-45>0$, 
pasangan nilai data $(67,65)$ diberi tanda negatif $(-)$ karena $65-67<0$, dan seterusnya.

$\Rightarrow$ Selanjutnya akan ditentukan nilai dari $n$. Perhatikan bahwa $n$ menyatakan jumlah dari tanda positif $(+)$ dan tanda negatif (-). Berdasarkan Tabel 1.4, tanda positif (+) berjumlah 12 dan tanda negatif $(-)$ berjumlah 2 , sehingga nilai $n$ adalah $12+2=14$.

$\Rightarrow$ Kemudian akan dihitung nilai probabilitas kumulatif dari nilai $X$. Perhatikan bahwa nilai $X$ menyatakan jumlah tanda yang paling sedikit, yakni antara tanda positif $(+)$ atau tanda negatif (-). Diketahui jumlah tanda positif sebanyak 12 dan jumlah tanda negatif (-) sebanyak 2, sehingga nilai $X$ adalah 2. Berikut akan dihitung nilai probabilitas kumulatif ( $p$-value) dari nilai $X=2$.

$$
\begin{gathered}
2\left[\sum_{i=0}^{x}\left(\begin{array}{c}
n \\
i
\end{array}\right)\left(\frac{1}{2}\right)^{i}\left(\frac{1}{2}\right)^{n-i}\right] \\
2\left[\left(\begin{array}{c}
14 \\
0
\end{array}\right)\left(\frac{1}{2}\right)^{0}\left(\frac{1}{2}\right)^{14}+\left(\begin{array}{c}
14 \\
1
\end{array}\right)\left(\frac{1}{2}\right)^{1}\left(\frac{1}{2}\right)^{13}+\left(\begin{array}{c}
14 \\
2
\end{array}\right)\left(\frac{1}{2}\right)^{2}\left(\frac{1}{2}\right)^{12}\right] \\
2[0,000061+0,000855+0,005554]
\end{gathered}
$$$$
0,013 \text {. }
$$ 


\section{Tahap Keempat}

Tahap keempat adalah pengambilan keputusan terhadap hipotesis.

Jika nilai probabilitas kumulatif dari $X \geq \alpha$, maka $H_{0}$ diterima, $H_{1}$ ditolak.

Jika nilai probabilitas kumulatif dari $X<\alpha$, maka $H_{1}$ diterima, $H_{0}$ ditolak.

Berdasarkan perhitungan, diperoleh nilai probabilitas kumulatif untuk $X=2$ adalah 0,013, dan tingkat signifikansi yang akan dibandingkan adalah 0,05 . Karena nilai probabilitas kumulatif untuk $X=2$, yakni 0,013, lebih kecil dari nilai tingkat signifikansi, yakni 0,05, maka hipotesis nol ditolak dan hipotesis alternatif diterima. Ini berarti pernyataan mengenai "terdapat perbedaan berat badan sebelum mengkonsumsi obat penambah berat badan merek XYZ dan sesudah mengkonsumsi obat penambah berat badan merek XYZ selama satu minggu" dapat diterima pada tingkat signifikansi 5\%. Dengan kata lain, terdapat pengaruh yang signifikan secara statistika mengenai berat badan, sebelum dan setelah mengkonsumsi obat penambah berat badan merek XYZ selama satu minggu. 


\section{UJI WILCOXON}

Uji peringkat bertanda Wilcoxon dikembangkan oleh Frank Wilcoxon. Uji peringkat bertanda Wilcoxon dan uji tanda samasama menguji dua buah populasi berpasangan. Pada uji tanda hanya memperhatikan arah (direction) dari selisih untuk setiap pasangan nilai data, sedangkan pada uji Wilcoxon, selain memperhatikan arah (tanda positif $(+)$ atau tanda negatif $(-)$ ) dari selisih untuk setiap pasangan nilai data, juga mengukur jarak atau besar (magnitude) dari selisih untuk setiap pasangan nilai data. Oleh karena itu, uji peringkat bertanda Wilcoxon lebih banyak memberikan informasi dibandingkan uji tanda.Misalkan diberikan data mengenai berat badan sebelum mengkonsumsi obat penambah berat badan merek $X Y Z$ dan sesudah mengkonsumsi obat penambah berat badan merek $X Y Z$ selama satu minggu.

Tabel 2.1

\begin{tabular}{|c|c|c|c|c|c|c|c|c|c|c|}
\hline Nama & A & B & C & D & E & F & G & H & I & Total \\
\hline$P$ & $45 \mathrm{~kg}$ & $50 \mathrm{~kg}$ & $35 \mathrm{~kg}$ & $45 \mathrm{~kg}$ & $54 \mathrm{~kg}$ & $44 \mathrm{~kg}$ & $41 \mathrm{~kg}$ & $44 \mathrm{~kg}$ & $35 \mathrm{~kg}$ & \\
\hline$Q$ & $44 \mathrm{~kg}$ & $50 \mathrm{~kg}$ & $37 \mathrm{~kg}$ & $50 \mathrm{~kg}$ & $57 \mathrm{~kg}$ & $48 \mathrm{~kg}$ & $45 \mathrm{~kg}$ & $44 \mathrm{~kg}$ & $35 \mathrm{~kg}$ & \\
\hline$Q-P$ & -1 & 0 & +2 & +5 & +3 & +4 & +4 & 0 & 0 & \\
\hline$|Q-P|$ & 1 & & 2 & 5 & 3 & 4 & 4 & & & \\
\hline Ranking & 1 & & 2 & 6 & 3 & 4,5 & 4,5 & & & \\
\hline Tanda + & & & 2 & 6 & 3 & 4,5 & 4,5 & & & 20 \\
\hline Tanda - & 1 & & & & & & & & & 1
\end{tabular}


Pada uji peringkat bertanda Wilcoxon, pertama dihitung selisih untuk setiap pasangan nilai data. Perhatikan bahwa pada Tabel 2.1 untuk baris $Q-P$, dihitung selisih untuk setiap pasangan nilai data. Pada uji tanda, selisih untuk pasangan nilai data hanya dinyatakan oleh tanda positif $(+)$, tanda negatif $(-)$, atau nilai 0 , sedangkan pada uji peringkat bertanda Wilcoxon, selain memperhatikan tanda dari selisih untuk untuk pasangan nilai data, uji peringkat bertanda Wilcoxon juga mengukur jarak atau besar (magnitude) dari selisih untuk pasangan nilai data. Selanjutnya, nilai selisih untuk setiap pasangan nilai data diabsolutkan, seperti pada baris $|Q-P|$ pada Tabel 2.1. Pada uji peringkat bertanda Wilcoxon, nilai $Q-P=0$ tidak diikutsertakan dalam analisis lebih lanjut. Kemudian, nilai absolut dari selisih untuk setiap pasangan nilai data diberi ranking atau peringkat, seperti pada baris Ranking pada Tabel 2.1. Selanjutnya nilai ranking tersebut dikelompokkan berdasarkan tanda positif $(+)$ atau tanda negatif (-), seperti pada baris Tanda + dan Tanda - pada Tabel 2.1. Perhatikan bahwa, berdasarkan Tabel 2.1, jumlah ranking untuk tanda positif $(+)$ sebanyak 20, sedangkan jumlah ranking untuk tanda negatif $(-)$ sebanyak 1 .

Uji statistik yang digunakan pada uji peringkat bertanda Wilcoxon adalah uji statistik Wilcoxon $\left(W_{\text {hitung }}\right)$. Nilai statistik dari uji Wilcoxon merupakan nilai dari jumlah ranking yang paling kecil, yakni antara jumlah ranking untuk tanda positif $(+)$ atau jumlah ranking untuk tanda negatif (-). Berdasarkan Tabel 2.1, nilai 
statistik dari uji Wilcoxon adalah $W_{\text {hitung }}=\min (20 ; 1)=1$. Setelah diperoleh nilai statistik dari uji Wilcoxon $\left(W_{\text {hitung }}\right)$, kemudian menentukan nilai kritis Wilcoxon $\left(W_{k r i t i s}\right)$ yang diperoleh berdasarkan tabel distribusi Wilcoxon. Berikut aturan pengambilan keputusan terhadap hipotesis.

Jika $W_{\text {hitung }} \leq W_{\text {kritis }}, H_{1}$ diterima dan $H_{0}$ ditolak. Jika $W_{\text {hitung }}>W_{\text {kritis }}, H_{0}$ diterima dan $H_{1}$ ditolak.

Selain itu, penyelesaian pada uji peringkat bertanda Wilcoxon dapat diselesaikan dengan pendekatan normal atau uji statistik $Z$. jika ukuran sampel cukup besar (moderately large), yakni ukuran sampel lebih dari 20, maka pendekatan normal dapat digunakan. Montgomery dan Runger (2014:364) menyatakan sebagai berikut.

"If the sample size is moderately large, say, $n>20$, it can be shown that $W^{+}$(or $W^{-}$) has approximately a normal distribution with mean

$$
\mu_{W^{+}}=\frac{n(n+1)}{4}, \text { and variance } \sigma_{W^{+}}^{2}=\frac{n(n+1)(2 n+1)}{24} .
$$

Nilai statistik dari uji Wilcoxon terlebih dahulu ditransformasi ke dalam bentuk nilai normal $Z$ terstandarisasi. Berikut rumus untuk mentransformasi nilai statistik dari uji Wilcoxon ke dalam bentuk nilai normal $Z$ terstandarisasi.

$$
Z=\frac{W_{\text {hitung }}-\left[\frac{(n)(n+1)}{4}\right]}{\sqrt{\frac{(n)(n+1)(2 n+1)}{24}}} .
$$


Setelah memperoleh nilai normal $Z$ terstandarisasi, kemudian pengambilan keputusan terhadap hipotesis dapat ditentukan dengan cara membandingkan probabilitas kumulatif dari nilai normal $Z$ terstandarisasi terhadap tingkat signifikansi $(\alpha)$ yang digunakan.

Jika nilai probabilitas kumulatif dari $Z \geq \alpha$, maka $H_{0}$ diterima, $H_{1}$ ditolak.

Jika nilai probabilitas kumulatif dari $Z<\alpha$, maka $H_{1}$ diterima, $H_{0}$ ditolak.

Tabel 2.2 menyajikan nilai probabilitas kumulatif dari nilai normal $Z$.

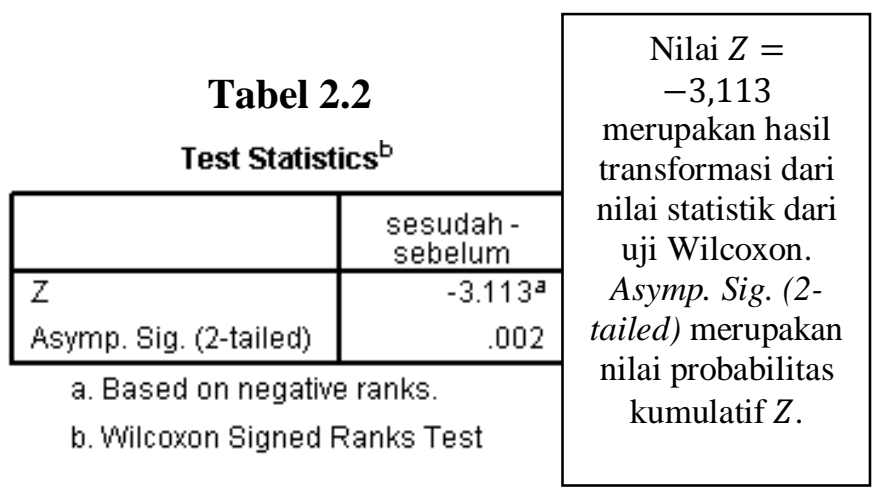

Contoh yang sama pada uji tanda akan diselesaikan dengan uji peringkat bertanda Wilcoxon. Misalkan seorang ahli farmasi ingin mengetahui ada tidaknya pengaruh yang signifikan secara statistika mengenai berat badan, sebelum mengkonsumsi obat penambah berat badan merek $X Y Z$ dan sesudah mengkonsumsi obat penambah berat badan merek $X Y Z$ selama satu minggu. 


\section{Tahap Pertama}

Tahap pertama adalah perumusan hipotesis. Berikut perumusan hipotesis.

$H_{0}$ : Tidak terdapat perbedaan berat badan sebelum mengkonsumsi obat penambah berat badan merek $X Y Z$ dan sesudah mengkonsumsi obat penambah berat badan merek $X Y Z$ selama satu minggu atau dapat dinyatakan $\mu_{X}=\mu_{Y}$.

$H_{1}$ : Terdapat perbedaan berat badan sebelum mengkonsumsi obat penambah berat badan merek $X Y Z$ dan sesudah mengkonsumsi obat penambah berat badan merek $X Y Z$ selama satu minggu atau dapat dinyatakan $\mu_{X} \neq \mu_{Y}$.

\section{Tahap Kedua}

Tahap kedua adalah menghitung nilai kritis Wilcoxon $\left(W_{\text {kritis }}\right)$ berdasarkan tabel distribusi Wilcoxon. Diketahui banyaknya nilai $Q-P$ yang bertanda positif dan negatif, yakni $n$ adalah 14 (lihat Tabel 2.3). Nilai kritis Wilcoxon dengan tingkat signifikansi 5\% dan $n=14$ adalah 21 (lihat tabel distribusi Wilcoxon untuk menentukan nilai kritis Wilcoxon).

\section{Tahap Ketiga}

Tahap ketiga adalah menghitung nilai statistik dari uji Wilcoxon ( $\left.W_{\text {hitung }}\right)$. 
Tabel 2.3

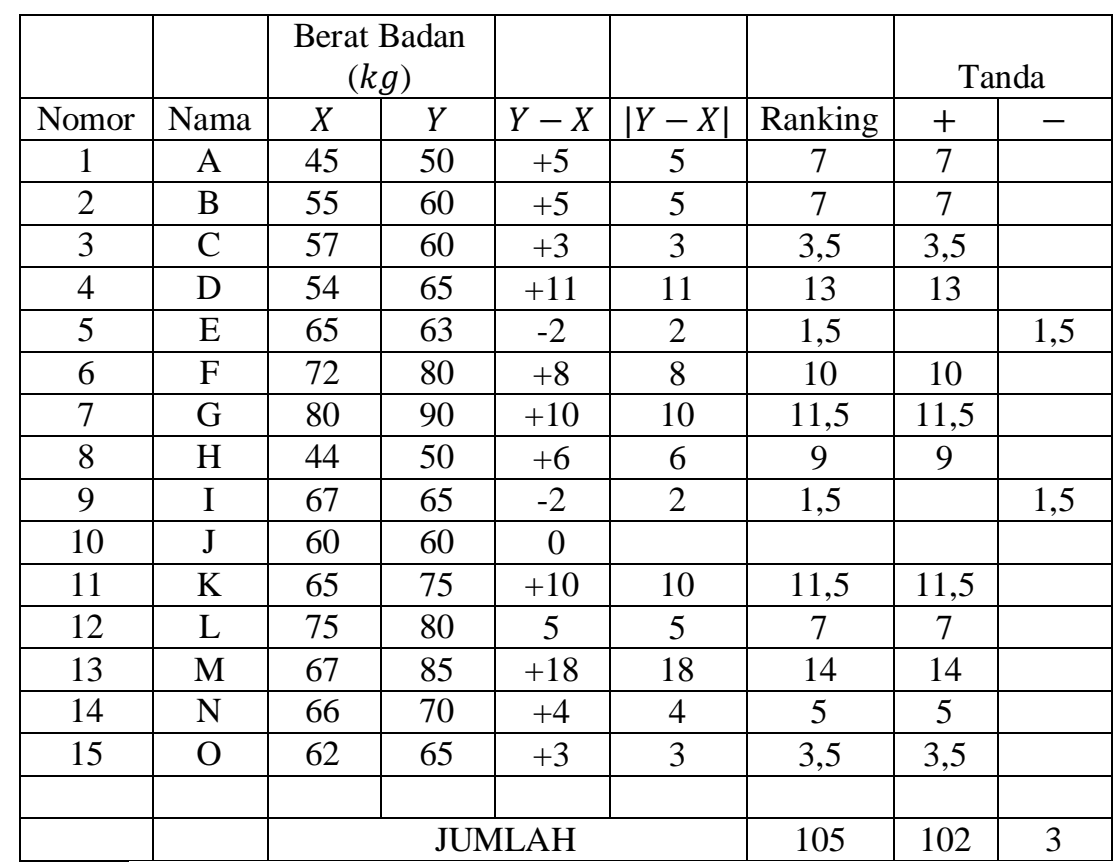

$\Rightarrow$ Nilai absolut dari selisih untuk setiap pasangan data diberi ranking atau peringkat. Berdasarkan data pada Tabel 2.3, data $|Y-X|$ secara berurutan adalah $5,5,3,11,2,8,10$, $6,2,10,5,18,4$, dan 3 . Data $|Y-X|$ yang bernilai 0 tidak diikutkan dalam analisis. Selanjutnya data tersebut diurutkan dari yang paling kecil sampai yang paling besar (lihat Tabel 2.4).

Tabel 2.4 Data $|Y-X|$ setelah Diurutkan

\begin{tabular}{|c|c|c|c|}
\hline Urutan ke & $|Y-X|$ & Urutan ke & $|Y-X|$ \\
\hline 1 & 2 & 8 & 5 \\
\hline 2 & 2 & 9 & 7 \\
\hline 3 & 3 & 10 & 8 \\
\hline 4 & 3 & 11 & 10 \\
\hline 5 & 4 & 12 & 10 \\
\hline 6 & 5 & 13 & 11 \\
\hline 7 & 5 & 14 & 18 \\
\hline
\end{tabular}


Data $|Y-X|$ dengan nilai 2 terdapat dua buah, yakni berada pada urutan ke-1 dan urutan ke-2. Data $|Y-X|$ dengan nilai 18 berada pada urutan terakhir, yakni urutan ke-14.

Nilai ranking untuk data $|Y-X|$ dengan nilai 2 adalah 1,5. Nilai ranking tersebut merupakan rata-rata dari nilai urutan data $|Y-X|$ dengan nilai 2 .

$$
\frac{1+2}{2}=1,5
$$

Data $|Y-X|$ dengan nilai 5 terdapat tiga buah, yakni berada pada urutan 6,7 , dan 8 . Nilai ranking untuk data $|Y-X|$ dengan nilai 5 adalah 7. Nilai ranking tersebut merupakan rata-rata dari urutan data $|Y-X|$ dengan nilai 5.

$$
\frac{6+7+8}{3}=7
$$

$\Rightarrow$ Selanjutnya nilai ranking dikelompokkan berdasarkan tanda positif $(+)$ atau tanda negatif $(-)$. Jika $(Y-X)$ bernilai negatif, maka nilai ranking dikelompokkan ke dalam kelompok tanda negatif $(-)$. Jika $(Y-X)$ bernilai positif, maka nilai ranking dikelompokkan ke dalam kelompok tanda positif $(+)$. Sebagai contoh $(Y-X)=$ -2 memiliki nilai ranking 1,5 . Karena $(Y-X)$ bernilai negatif, yakni -2 , maka nilai ranking 1,5 dikelompokkan 
ke dalam kelompok tanda negatif $(-)$. Perhatikan juga bahwa $(Y-X)=11$ memiliki ranking 13. Karena $(Y-X)$ bernilai positif, yakni 11, maka nilai ranking 13 dikelompokkan ke dalam kelompok tanda positif $(+)$.

$\Rightarrow$ Kemudian menentukan nilai $n$. Perhatikan bahwan merupakan banyaknya nilai $Y-X$ yang bertanda positif $(+)$ atau negatif $(-)$. Berdasarkan data pada Tabel 2.3, nilai selisih $Y-X>0$ berjumlah 12 , sedangkan nilai selisih $Y-X<0$ berjumlah 2 , sehingga nilai $n$ adalah $2+12=14$.

$\Rightarrow$ Selanjutnya menjumlahkan ranking berdasarkan tanda positif $(+)$ dan tanda negatif $(-)$. Berdasarkan data pada Tabel 2.3, jumlah ranking untuk tanda positif $(+)$ adalah 102 dan jumlah ranking untuk tanda negatif (-) adalah 3. Nilai statistik dari uji Wilcoxon merupakan nilai dengan jumlah ranking yang paling kecil, yakni antara jumlah ranking untuk tanda positif $(+)$ atau jumlah ranking untuk tanda negatif $(-)$. Berdasarkan Tabel 2.3, nilai statistik dari uji Wilcoxon adalah $W_{\text {hitung }}=\min (102 ; 3)=3$.

\section{Tahap Keempat}

Tahap keempat adalah pengambilan keputusan terhadap hipotesis. Berikut aturan dalam pengambilan keputusan terhadap hipotesis.

Jika $W_{\text {hitung }} \leq W_{\text {kritis }}, H_{1}$ diterima dan $H_{0}$ ditolak. Jika $W_{\text {hitung }}>W_{\text {kritis }}, H_{0}$ diterima dan $H_{1}$ ditolak. 
Diketahui nilai statistik dari uji Wilcoxon adalah 3 dan nilai kritis Wilcoxon adalah 21. Karena nilai statistik dari uji Wilcoxon, yakni 3 lebih kecil dari nilai kritis Wilcoxon, yakni 21, maka hipotesis nol ditolak dan hipotesis alternatif diterima. Ini berarti pernyataan mengenai "terdapat perbedaan yang signifikan (secara statistika) mengenai berat badan, sebelum mengkonsumsi obat penambah berat badan merek $X Y Z$ dan sesudah mengkonsumsi obat penambah berat badan merek $X Y Z$ selama satu minggu" dapat diterima pada tingkat signifikansi $5 \%$.

\section{Penyelesaian dengan Pendekatan Normal}

Lakukan transformasi terhadap nilai statistik dari uji Wilcoxon menjadi nilai normal $Z$ terstandarisasi. Berikut rumus untuk mentransformasi nilai statistik dari uji Wilcoxon menjadi nilai normal $Z$ terstandarisasi.

$$
Z=\frac{W_{\text {hitung }}-\left[\frac{(n)(n+1)}{4}\right]}{\sqrt{\frac{(n)(n+1)(2 n+1)}{24}}}
$$

Berdasarkan perhitungan sebelumnya, nilai statistik dari uji Wilcoxon adalah 3 , sehingga

$$
\begin{gathered}
Z=\frac{3-\left[\frac{(14)(14+1)}{4}\right]}{\sqrt{\frac{(14)(14+1)(2 \times 14+1)}{24}}} \\
Z=\frac{-49,5}{15,92953232}
\end{gathered}
$$




$$
Z=-3,108 \text { atau }-3,11 \text {. }
$$

Nilai normal $Z$ terstandarisasi adalah $-3,11$. Nilai probabilitas kumulatif dari $Z=-3,11$ berdasarkan tabel distribusi normal kumulatif adalah 0,0009. Dengan Microsoft Excel dapat dihitung sebagai berikut (Gambar 2.1).

\begin{tabular}{|c|c|c|}
\hline \multicolumn{2}{|c|}{ Alignment } \\
\hline \hline$f_{\mathbf{s}}$ & $=$ NORMSDIST(D3) \\
\hline \hline & $\mathrm{D}$ & $\mathrm{E}$ \\
\hline & & \\
\hline $\mathrm{Z}$ & Probabilitas Kumulatif \\
\hline -3.11 & 0.000935437 \\
\hline
\end{tabular}

\section{Gambar 2.1}

Karena pengujian hipotesis dua arah, maka nilai probabilitas kumulatif yang akan dibandingkan dengan tingkat signifikansi adalah

$$
2 \times 0,0009=0,0018 \text { atau } 0,002 \text {. }
$$

Perhatikan bahwa karena nilai probabilitas kumulatif 0,002< $\alpha=0,05$, maka hipotesis nol ditolak dan hipotesis alternatif diterima. Ini berarti pernyataan mengenai "terdapat perbedaan yang signifikan secara statistika mengenai berat badan, sebelum mengkonsumsi obat penambah berat badan merek $X Y Z$ dan sesudah mengkonsumsi obat penambah berat badan merek $X Y Z$ selama satu minggu" dapat diterima pada tingkat signifikansi 5\%. 


\section{UJI MANN-WHITNEY}

Uji Mann-Whitney merupakan uji nonparametrik yang digunakan untuk menguji ada tidaknya perbedaan dari dua populasi yang saling independen. Uji Mann-Whitney merupakan alternatif dari uji $t$ untuk dua populasi independen ketika asumsi normalitas populasi tidak terpenuhi.

Sebagai contoh kasus, andaikan seorang dosen ingin meneliti mengenai ada tidaknya perbedaan yang signifikan secara statistika pada nilai ujian matakuliah kalkulus antara mahasiswa jurusan matematika dan mahasiswa jurusan statistika. Untuk keperluan penelitian, dosen tersebut mengambil sampel sebanyak 8 nilai ujian matakuliah kalkulus yang terdiri dari 4 nilai ujian matakuliah kalkulus mahasiswa jurusan matematika dan 4 nilai ujian matakuliah kalkulus mahasiswa jurusan statistika. Data disajikan pada Tabel 3.1.

Tabel 3.1 (Data Fiktif) 


\begin{tabular}{|c|c|c|c|c|c|}
\hline Nama & $X$ & $R(X)$ & Nama & $Y$ & $R(Y)$ \\
\hline Ugi & 65 & 2 & Andi & 80 & 5,5 \\
\hline Mifdhal & 68 & 3 & Firdaus & 90 & 7 \\
\hline Igbal & 70 & 4 & Joko & 95 & 8 \\
\hline Alan & 80 & 5,5 & Mamat & 50 & 1 \\
\hline & & & & & \\
\hline \multicolumn{2}{|c|}{ Total $R(X)$} & 14,5 & \multicolumn{2}{|c|}{ Total $R(Y)$} & 21,5 \\
\hline
\end{tabular}

Berdasarkan data pada Tabel 3.1, misalkan $X$ merupakan sampel nilai ujian matakuliah kalkulus mahasiswa jurusan matematika, sedangkan $Y$ merupakan sampel nilai ujian matakuliah kalkulus mahasiswa jurusan statistika. Pada uji Mann-Whitney perlu ditentukan nilai ranking untuk masing-masing nilai data dari kedua sampel. Untuk menentukan nilai ranking dari masingmasing nilai data dari kedua sampel, gabungkan seluruh nilai data dari kedua sampel. Selanjutnya, sajikan nilai-nilai tersebut dimulai dari nilai yang paling kecil hingga nilai yang paling besar. Perhatikan Tabel 3.2.

\section{Tabel 3.2}

\begin{tabular}{|c|c|c|c|c|c|c|c|c|}
\hline Urutan & 1 & 2 & 3 & 4 & 5 & 6 & 7 & 8 \\
\hline Nilai & 50 & 65 & 68 & 70 & 80 & 80 & 90 & 95 \\
\hline Ranking & 1 & 2 & 3 & 4 & 5,5 & 5,5 & 7 & 8 \\
\hline
\end{tabular}

Berdasarkan data pada Tabel 3.2, nilai 50 berada pada urutan pertama karena nilai tersebut merupakan nilai paling kecil, sedangkan nilai 80 berada pada urutan kelima dan keenam. Selanjutnya, untuk setiap nilai data dari kedua sampel diberi ranking. Untuk nilai data 50 diberi ranking 1, karena terletak pada 
urutan pertama. Namun perhatikan bahwa untuk nilai data 80 diberi ranking 5,5. Perhatikan bahwa nilai data 80 terletak pada urutan kelima dan keenam, sehingga

$$
\text { nilai ranking } 80=\frac{5+6}{2}=5,5
$$

Setelah masing-masing nilai data dari kedua sampel diberi ranking, maka jumlahkan ranking untuk masing-masing sampel. Berdasarkan Tabel 3.1, jumlah ranking nilai ujian matakuliah kalkulus untuk sampel mahasiswa jurusan matematika $(R(X))$ adalah 14,5, sedangkan jumlah ranking nilai ujian matakuliah kalkulus untuk sampel mahasiswa jurusan statistika $(R(Y))$ adalah 21,5.Setelah menghitung jumlah ranking untuk masingmasing nilai data dari kedua sampel, maka akan ditentukan nilai statistik dari uji Mann-Whitney $\left(U_{\text {hitung }}\right)$.

$$
\begin{aligned}
& U_{1}=n_{1} n_{2}+\frac{\left(n_{1}\right)\left(n_{1}+1\right)}{2}-R_{1} \\
& U_{2}=n_{1} n_{2}+\frac{\left(n_{2}\right)\left(n_{2}+1\right)}{2}-R_{2} .
\end{aligned}
$$

Perhatikan bahwa $n_{1}$ menyatakan jumlah elemen atau pengamatan pada sampel pertama, $n_{2}$ menyatakan jumlah elemen atau pengamatan pada sampel kedua, $R_{1}$ menyatakan jumlah ranking pada sampel pertama, dan $R_{2}$ menyatakan jumlah ranking pada sampel kedua. Nilai statistik dari uji Mann-Whitney merupakan $U_{\text {hitung }}=\operatorname{minimum}\left(U_{1}, U_{2}\right)$. Setelah memperoleh nilai statistik dari uji Mann-Whitney, kemudian dibandingkan dengan nilai 
kritis Mann-Whitney $\left(U_{\text {kritis }}\right)$ berdasarkan tabel distribusi MannWhitney. Berikut aturan pengambilan keputusan terhadap hipotesis.

$$
\begin{aligned}
& U_{\text {hitung }} \leq U_{\text {kritis }}, H_{1} \text { diterima }, H_{0} \text { ditolak. } \\
& U_{\text {hitung }}>U_{\text {kritis }}, H_{0} \text { diterima, } H_{1} \text { ditolak. }
\end{aligned}
$$

Selain itu, penyelesaian pada uji uji Mann-Whitney dapat diselesaikan dengan pendekatan normal atau uji statistik $Z$. Jika ukuran sampel cukup besar (moderately large), yakni $n_{1}$ dan $n_{2}$ lebih besar dari 8, maka pendekatan normal dapat digunakan. Montgomery dan Runger (2014:398) menyatakan sebagai berikut.

"When both $n_{1}$ and $n_{2}$ are moderately large, say, more than eight, the distribution of $w_{1}$ can be well approximated by normal distribution with mean

$$
\mu_{w_{1}}=\frac{n_{1}\left(n_{1}+n_{2}+1\right)}{2}
$$

and variance

$$
\sigma_{w_{1}}^{2}=\frac{n_{1} n_{2}\left(n_{1}+n_{2}+1\right)}{12}
$$

Therefore, for $n_{1}$ and $n_{2}>8$, we could use $Z_{0}=\frac{W_{1}-\mu_{w_{1}}}{\sigma_{w_{1}}}$."

Nilai statistik dari uji Mann-Whitney terlebih dahulu ditransformasi ke dalam bentuk nilai normal $Z$ terstandarisasi. Berikut rumus untuk mentransformasi nilai statistik dari uji MannWhitney ke dalam bentuk nilai normal $Z$ terstandarisasi. 


$$
Z=\frac{U-\left[\frac{n_{1} n_{2}}{2}\right]}{\sqrt{\frac{\left(n_{1}\right)\left(n_{2}\right)\left(n_{1}+n_{2}+1\right)}{12}}}
$$

Setelah memperoleh nilai normal $Z$ terstandarisasi, kemudian pengambilan keputusan terhadap hipotesis dapat ditentukan dengan cara membandingkan probabilitas kumulatif dari nilai normal $Z$ terstandarisasi terhadap tingkat signifikansi yang digunakan.Tabel 3.3 menyajikan nilai probabilitas kumulatif dari nilai normal $Z$ terstandarisasi.

Tabel 3.3

\begin{tabular}{|c|c|}
\hline & nilai \\
\hline v1ann-w'vitney $\cup$ & 17.500 \\
\hline wilcoxon w' & 72.500 \\
\hline$Z$ & -2.497 \\
\hline Asymp. Sig. (2-tailed) & .013 \\
\hline $\begin{array}{l}\text { Exact Sig. [2*(1-tailed } \\
\text { Sig.)] }\end{array}$ & $.011^{a}$ \\
\hline
\end{tabular}

Mann-Whitney $U$ merupakan nilai statistik dari uji Mann-Whitney. Asymp. Sig. (2tailed) merupakan nilai probabilitas dari nilai normal $Z=-2,497$ terstandarisasi.

Sebagai contoh kasus, misalkan seorang dosen ingin meneliti mengenai ada tidaknya perbedaan yang signifikan secara statistika pada nilai ujian matakuliah kalkulus antara mahasiswa jurusan matematika dan mahasiswa jurusan statistika. Untuk keperluan penelitian, dosen tersebut mengambil sampel sebanyak 20 nilai ujian matakuliah kalkulus yang terdiri dari 10 nilai ujian matakuliah kalkulus mahasiswa jurusan matematika dan 10 nilai ujian matakuliah kalkulus mahasiswa jurusan statistika. Data yang telah dikumpulkan disajikan pada Tabel 3.4. 
Tabel 3.4 (Data Fiktif)

\begin{tabular}{|c|c|c|c|}
\hline $\begin{array}{c}\text { Nama Siswa Jurusan } \\
\text { Matematika }\end{array}$ & $X$ & $\begin{array}{c}\text { Nama Siswa Jurusan } \\
\text { Statistika }\end{array}$ & $Y$ \\
\hline Ugi & 65 & Andi & 85 \\
\hline Mifdhal & 68 & Firdaus & 75 \\
\hline Iqbal & 70 & Joko & 75 \\
\hline Alan & 80 & Mamat & 80 \\
\hline John & 75 & Dani & 75 \\
\hline Andre & 72 & Darma & 75 \\
\hline Ridho & 65 & Febri & 75 \\
\hline Hanafi & 60 & Oman & 80 \\
\hline Romi & 88 & Wily & 90 \\
\hline Hasoloan & 70 & Wawan & 85 \\
\hline
\end{tabular}

Berdasarkan data pada Tabel 3.4, misalkan $X$ merupakan sampel nilai ujian matakuliah kalkulus mahasiswa jurusan matematika, sedangkan $Y$ merupakan sampel nilai ujian matakuliah kalkulus mahasiswa jurusan statistika. Dalam hal ini, Uji Mann-Whitney digunakan untuk menguji apakah terdapat perbedaan yang signifikan secara statistika mengenai nilai ujian matakuliah kalkulus antara mahasiswa jurusan matematika dengan jurusan statistika.

\section{Tahap Pertama}

Tahap pertama adalah perumusan hipotesis. Berikut perumusan hipotesis.

$H_{0}$ : Tidak terdapat perbedaan yang signifikan secara statistika mengenai nilai ujian matakuliah kalkulus antara mahasiswa jurusan matematika dan mahasiswa jurusan statistika. 
$H_{1}$ : Terdapat perbedaan yang signifikan secara statistika mengenai nilai ujian matakuliah kalkulus antara mahasiswa jurusan matematika dan mahasiswa jurusan statistika.

\section{Tahap Kedua}

Tahap kedua adalah menentukan nilai kritis Mann-Whitney $\left(U_{\text {kritis }}\right)$ berdasarkan tabel distribusi Mann-Whitney. Diketahui jumlah nilai data dalam sampel nilai ujian matakuliah kalkulus jurusan matematika $\left(n_{1}\right)$ adalah 10 , jurusan statistika $\left(n_{2}\right)$ adalah 10, dan tingkat signifikansi 0,05, sehingga nilai kritis MannWhitney berdasarkan tabel distribusi Mann-Whitney adalah 23.

\section{Tahap Ketiga}

Tahap ketiga adalah menghitung nilai statistik dari uji MannWhitney $\left(U_{\text {hitung }}\right)$.

Tabel 3.5

\begin{tabular}{|c|l|l|l|l|l|l|l|l|l|l|l|}
\cline { 9 - 12 } & & & & & & & & & & Total \\
\hline Nama & Ugi & Mifdhal & Iqbal & Alan & John & Andre & Ridho & Hanafi & Romi & Hasoloan & \\
\hline$X$ & 65 & 68 & 70 & 80 & 75 & 72 & 65 & 60 & 88 & 70 & \\
\hline$R(X)$ & 2,5 & 4 & 5,5 & 15 & 10,5 & 7 & 2,5 & 1 & 19 & 5,5 & 72,5 \\
\hline Nama & Andi & Firdaus & Joko & Mamat & Dani & Darma & Febri & Oman & Wily & Wawan & \\
\hline$Y$ & 85 & 75 & 75 & 80 & 75 & 75 & 75 & 80 & 90 & 85 & \\
\hline$R(Y)$ & 17,5 & 10,5 & 10,5 & 15 & 10,5 & 10,5 & 10,5 & 15 & 20 & 17,5 & 137,5 \\
\hline
\end{tabular}

$\Rightarrow$ Gabungkan seluruh nilai ujian matakuliah kalkulus antara mahasiswa jurusan matematika dan mahasiswa jurusan statistika (Tabel 3.6). 
Tabel 3.6

\begin{tabular}{|l|l|l|l|l|l|l|l|l|l|l|}
\hline Nama & Ugi & Mifdhal & Iqbal & Alan & John & Andre & Ridho & Hanafi & Romi & Hasoloari \\
\hline Nilai & 65 & 68 & 70 & 80 & 75 & 72 & 65 & 60 & 88 & 70 \\
\hline Nama & Andi & Firdaus & Joko & Mamat & Dani & Darma & Febri & Oman & Wily & Wawan \\
\hline Nilai & 85 & 75 & 75 & 80 & 75 & 75 & 75 & 80 & 90 & 85 \\
\hline
\end{tabular}

$\Rightarrow$ Urutkan nilai ujian matakuliah kalkulus dari yang paling kecil sampai yang paling besar (Tabel 3.7).

Nilai Hanafi adalah 60. Nilai 60 merupakan nilai yang paling kecil, sehingga nilai 60 berada pada urutan pertama (Tabel 3.7). Nilai Ugi dan Ridho adalah sama, yakni 65. Nilai 65 berada pada urutan kedua dan ketiga. Nilai Wily adalah 90. Nilai 90 adalah nilai yang paling besar, sehingga nilai 90 terletak pada urutan terakhir, yakni urutan keduapuluh.

$\Rightarrow$ Selanjutnya beri ranking untuk setiap nilai ujian matakuliah kalkulus. Nilai ujian matakuliah kalkulus 65 terdapat dua buah nilai, yakni pada urutan kedua dan urutan ketiga, sehingga ranking untuk nilai ujian matakuliah kalkulus 65 adalah

$$
\frac{2+3}{2}=2,5
$$

Jadi, nilai ujian matakuliah kalkulus 60 diberi ranking 2,5. Untuk nilai ujian matakuliah kalkulus 75 terdapat enam buah nilai, yakni pada urutan kedelapan sampai dengan 
urutan ketigabelas, sehingga ranking untuk nilai ujian matakuliah kalkulus 75 adalah

$$
\frac{8+9+10+11+12+13}{6}=\frac{63}{3}=10,5
$$

dan seterusnya.

Tabel 3.7

\begin{tabular}{|c|c|c|c|c|c|c|c|c|c|c|}
\hline Urutan ke & 1 & 2 & 3 & 4 & 5 & 6 & 7 & 8 & 9 & 10 \\
\hline Nama & Hanafi & Ugi & Ridho & Mifdhal & Iqbal & Hasoloan & Andre & John & Firdaus & Joko: \\
\hline Nilai & 60 & 65 & 65 & 68 & 70 & 70 & 72 & 75 & 75 & 75 \\
\hline Urutan ke & 11 & 12 & 13 & 14 & 15 & 16 & 17 & 18 & 19 & 20 \\
\hline Nama & Dani & Darma & Febri & Alan & Mamat & Oman & Andi & Wawan & Romi & Wily \\
\hline Nilai & 75 & 75 & 75 & 80 & 80 & 80 & 85 & 85 & 88 & 90 \\
\hline
\end{tabular}

$\Rightarrow$ Jumlahkan ranking berdasarkan masing-masing jurusan. Berdasarkan Tabel 3.5, jumlah ranking nilai ujian matakuliah kalkulus mahasiswa jurusan matematika $R(X)$ adalah 72,5 dan jumlah ranking nilai ujian matakuliah kalkulus mahasiswa jurusan statistika $R(Y)$ adalah 137,5. Selanjutnya menghitung nilai $U_{1}$ dan $U_{2}$.

$$
\begin{gathered}
U_{1}=n_{1} n_{2}+\frac{\left(n_{1}\right)\left(n_{1}+1\right)}{2}-R_{1} \\
U_{2}=n_{1} n_{2}+\frac{\left(n_{2}\right)\left(n_{2}+1\right)}{2}-R_{2} \\
U_{1}=(10)(10)+\frac{(10)(10+1)}{2}-72,5=82,5 \\
U_{2}=(10)(10)+\frac{(10)(10+1)}{2}-137,5=17,5 .
\end{gathered}
$$

Sehingga nilai statistik dari uji Mann-Whitney adalah $U_{\text {hitung }}=\min (82,5: 17,5)=17,5$. 


\section{Tahap Keempat}

Tahap keempat adalah pengambilan keputusan terhadap hipotesis. Berikut aturan pengambilan keputusan terhadap hipotesis.

$$
\begin{aligned}
& U_{\text {hitung }} \leq U_{\text {kritis }}, H_{1} \text { diterima, } H_{0} \text { ditolak. } \\
& U_{\text {hitung }}>U_{\text {kritis }}, H_{0} \text { diterima, } H_{1} \text { ditolak. }
\end{aligned}
$$

Diketahui nilai statistik dari uji Mann-Whitney adalah 17,5, sedangkan nilai kritis Mann-Whitney adalah 23. Karena nilai dari statistik dari uji Mann-Whitney, yakni 17,5 lebih kecil dari nilai kritis Mann-Whitney, yakni 23, maka hipotesis nol ditolak dan hipotesis alternatif diterima. Ini berarti pernyataan mengenai "terdapat perbedaan yang signifikan secara statistika mengenai nilai ujian matakuliah kalkulus antara mahasiswa jurusan matematika dan mahasiswa jurusan statistika" dapat diterima pada tingkat signifikansi 5\%.

\section{Penyelesaian dengan Pendekatan Normal}

Lakukan transformasi nilai statistik dari uji Mann-Whitney menjadi nilai normal $Z$ terstandarisasi. Berikut rumus untuk mentransformasi nilai statistik dari uji Mann-Whitney menjadi nilai normal $Z$ terstandarisasi.

$$
Z=\frac{U_{\text {hitung }}-\left[\frac{n_{1} n_{2}}{2}\right]}{\sqrt{\frac{\left(n_{1}\right)\left(n_{2}\right)\left(n_{1}+n_{2}+1\right)}{12}}} .
$$

Berdasarkan perhitungan sebelumnya, nilai statistik dari uji Mann-Whitney adalah 17,5, sehingga 


$$
\begin{gathered}
Z=\frac{17,5-\left[\frac{(10)(10)}{2}\right]}{\sqrt{\frac{(10)(10)(10+10+1)}{12}}} \\
Z=\frac{-32,5}{13,22876} \\
Z=-2,456 \text { atau }-2,46 .
\end{gathered}
$$

Berdasarkan perhitungan diperoleh nilai normal $Z$ terstandarisasi adalah $-2,46$. Nilai probabilitas kumulatif dari $Z=-2,46$ berdasarkan tabel distribusi normal kumulatif adalah 0,0069 Diketahui pengujian hipotesis dua arah, sehingga probabilitas kumulatif yang akan dibandingkan dengan tingkat signifikansi adalah

$$
2 \times 0,0069=0,0138 \text { atau } 0,014 \text {. }
$$

Karena nilai probabilitas kumulatif, yakni $0,014<\alpha=0,05$, maka hipotesis nol ditolak dan hipotesis alternatif diterima. Ini berarti pernyataan "terdapat perbedaan nilai ujian matakuliah kalkulus antara mahasiswa jurusan statistika dan mahasiswa jurusan matematika" dapat diterima pada tingkat signifikansi 5\%. 


\section{UJI MCNEMAR}

Uji McNemar merupakan uji nonparametrik yang digunakan untuk menguji dua buah populasi yang saling berpasangan. Pada uji McNemar, sekelompok subjek penelitian (misalkan sekelompok orang) memberikan suatu penilaian sebelum dan sesudah perlakuan. Masing-masing subjek penelitian hanya memiliki dua macam penilaian (dichotomous outcomes) untuk setiap perlakuan yang diberikan. Dua penilaian tersebut bersifat saling berlawanan atau dikotomi. Contoh dari dua penilaian yang bersifat saling berlawanan, yakni "benar atau salah", "sukses atau gagal", "ikut atau tidak ikut", "datang atau tidak datang”, "sulit atau tidak sulit", dan sebagainya. Misalkan "1" menyatakan kejadian "sukses", sedangkan "0" menyatakan kejadian "gagal”. Kemudian misalkan $(X, Y)$ menyatakan pasangan pengamatan/kejadian, dengan $X$ menyatakan kejadian sebelum perlakuan, sedangkan $Y$ menyatakan kejadian setelah perlakuan, maka $(X=1, Y=0)$ berarti kejadian sebelum perlakuan adalah sukses, sedangkan setelah perlakuan gagal, $(X=0, Y=0)$ berarti kejadian sebelum perlakuan adalah gagal dan setelah perlakuan juga gagal, dan seterusnya.

Hipotesis nol pada uji McNemar menyatakan tidak terdapat perbedaan efek atau pengaruh sebelum dan sesudah perlakuan. 
Dengan kata lain, probabilitas dari kejadian $(X=1, Y=0)$ atau $P(X=1, Y=0)$ sama dengan probabilitas untuk kejadian $(X=0, Y=1)$ atau $P(X=0, Y=1)$.

Hipotesis alternatif menyatakan terdapat perbedaan efek atau pengaruh sebelum dan sesudah perlakuan. Dengan kata lain, probabilitas dari kejadian $(X=1, Y=0)$ atau $P(X=1, Y=0)$ berbeda dengan probabilitas untuk kejadian $(X=0, Y=1)$ atau $P(X=0, Y=1)$. Dalam uji McNemar, data disajikan dalam tabel kontingensi $2 \times 2$. Berikut disajikan tabel kontingensi $2 \times 2$.

\section{Tabel 4.1}

\begin{tabular}{|c|c|c|c|}
\cline { 3 - 4 } \multicolumn{2}{c|}{} & \multicolumn{2}{c|}{$\begin{array}{c}\text { Sesudah } \\
\text { Perlakuan }\end{array}$} \\
\cline { 3 - 4 } \multicolumn{2}{c|}{} & 0 & 1 \\
\hline Sebelum & 0 & $a$ & $b$ \\
\cline { 3 - 4 } Perlakuan & 1 & $c$ & $d$ \\
\hline
\end{tabular}

Berdasarkan tabel kontingensi (Tabel 4.1), a merupakan jumlah subjek penelitian yang memberikan respon " 0 " sebelum perlakuan dan sesudah perlakuan, yang dinyatakan $(0,0), b$ merupakan jumlah subjek penelitian yang memberikan respon "0" sebelum perlakuan dan respon " 1 " setelah perlakuan, yang dinyatakan $(0,1)$, dan seterusnya. Conover (1999), Kvam dan Vidakovic (2007) mengemukakan ketika $b+c>20$, maka nilai statistik dari uji McNemar $\left(T_{1}\right)$ dihitung dengan rumus 


$$
T_{1}=\frac{(b-c)^{2}}{b+c}
$$

Lebih lanjut, Conover (1999) menyatakan $T_{1}$ semakin mendekati distribusi chi-kuadrat ketika $(b+c)$ semakin besar, dengan derajat bebas 1. Untuk pengambilan keputusan terhadap hipotesis, nilai statistik dari uji McNemar $\left(T_{1}\right)$ kemudian dibandingkan dengan nilai kritis chi-kuadrat $\left(\chi_{\text {kritis }}^{2}\right)$.

Jika $T_{1} \leq \chi_{\text {kritis }}^{2}, H_{0}$ diterima dan $H_{1}$ ditolak. Jika $T_{1}>\chi_{\text {kritis }}^{2}, H_{0}$ ditolak dan $H_{1}$ diterima.

Pengambilan keputusan terhadap hipotesis juga dapat digunakan dengan pendekatan nilai probabilitas dari $T_{1}$. Nilai probabilitas dari $T_{1}$ dibandingkan dengan tingkat signifikansi yang digunakan $(\alpha)$. Berikut aturan pengambilan keputusan terhadap hipotesis berdasarkan pendekatan nilai probabilitas.

Jika nilai probabilitas $T_{1} \geq \alpha$, maka $H_{0}$ diterima dan $H_{1}$ ditolak.

Jika nilai probabilitas $T_{1}<\alpha$, maka $H_{1}$ diterima dan $\mathrm{H}_{0}$ ditolak.

Rumus untuk menghitung nilai statistik dari uji $\operatorname{McNemar}\left(T_{2}\right)$, ketika $b+c \leq 20$ adalah sebagai berikut.

$$
T_{2}=2\left[\sum_{i=0}^{X}\left(\begin{array}{l}
n \\
i
\end{array}\right) p^{i} q^{n-i}\right]
$$


Perhatikan bahwa $n=b+c$, sedangkan $X=\min (b, c)$. Berikut aturan pengambilan keputusan terhadap hipotesis.

Jika $T_{2} \geq \alpha$, maka $H_{0}$ diterima dan $H_{1}$ ditolak.

Jika $T_{2}<\alpha$, maka $H_{1}$ diterima. dan $H_{0}$ ditolak.

Sebagai contoh kasus, misalkan seorang peneliti sedang meneliti apakah dengan adanya tayangan iklan yang mempromosikan bumbu masakan merek A, terjadi pengaruh yang cukup signifikan terhadap penggunaan bumbu masakan merek A. Berikut data yang telah dikumpulkan oleh peneliti (Tabel 4.2).

Tabel 4.2 (Data Fiktif)

\begin{tabular}{|c|c|c|c|c|c|}
\hline & & \multicolumn{4}{|c|}{ Pemberian Motivasi } \\
\hline No. & Nama & \multicolumn{2}{|c|}{ Sebelum Ada Iklan } & \multicolumn{2}{c|}{ Sesudah Ada Iklan } \\
\hline 1 & Hanafi & 0 & Tidak Menggunakan & 1 & Menggunakan \\
\hline 2 & Ridho & 0 & Tidak Menggunakan & 1 & Menggunakan \\
\hline 3 & Niar & 0 & Tidak Menggunakan & 1 & Menggunakan \\
\hline 4 & Fitri & 0 & Tidak Menggunakan & 1 & Menggunakan \\
\hline 5 & Ugi & 1 & Menggunakan & 0 & Tidak Menggunakan \\
\hline 6 & Romi & 1 & Menggunakan & 1 & Menggunakan \\
\hline 7 & Mifdal & 1 & Menggunakan & 1 & Menggunakan \\
\hline 8 & Iqbal & 1 & Menggunakan & 1 & Menggunakan \\
\hline 9 & Suci & 1 & Menggunakan & 1 & Menggunakan \\
\hline 10 & Melda & 0 & Tidak Menggunakan & 1 & Menggunakan \\
\hline 11 & Evelin & 0 & Tidak Menggunakan & 1 & Menggunakan \\
\hline 12 & Hasoloan & 0 & Tidak Menggunakan & 1 & Menggunakan \\
\hline 13 & John & 0 & Tidak Menggunakan & 0 & Tidak Menggunakan \\
\hline 14 & sri & 0 & Tidak Menggunakan & 0 & Tidak Menggunakan \\
\hline 15 & alan & 0 & Tidak Menggunakan & 1 & Menggunakan \\
\hline
\end{tabular}

Berdasarkan data pada Tabel 4.2, seorang yang bernama Hanafi tidak menggunakan bumbu masakan merek A sebelum ada iklan 
di televisi mengenai promosi bumbu masakan merek A. Namun setelah ada iklan di televisi mengenai bumbu masakan merek $\mathrm{A}$, ia menggunakan bumbu masakan merek A. Perhatikan bahwa kejadian tersebut dapat dilambangkan dengan $(0,1)$. Seorang yang bernama Ugi menggunakan bumbu masakan merek A sebelum ada iklan di televisi mengenai promosi bumbu masakan merek A. Namun, setelah ada iklan di televisi mengenai promosi bumbu masakan merek A, ia tidak lagi menggunakan bumbu masakan merek A. Perhatikan bahwa kejadian tersebut dapat dilambangkan dengan $(1,0)$.

Dengan menggunakan tingkat signifikansi 5\%, berikut akan digunakan uji McNemar untuk mengetahui apakah terdapat pengaruh yang signifikan secara statistika terhadap penggunaan bumbu masakan merek A, setelah adanya iklan promosi.

\section{Tahap Pertama}

Tahap pertama adalah perumusan hipotesis. Berikut perumusan hipotesis.

$H_{0}: P(0,1)=P(1,0)$ atau tidak terdapat pengaruh yang signifikan secara statistika pada penggunaan bumbu masakan mereka A, setelah adanya iklan promosi.

$H_{1}: P(0,1) \neq P(1,0)$ atau terdapat pengaruh yang signifikan secara statistika pada penggunaan bumbu masakan mereka A, setelah adanya iklan promosi. 


\section{Tahap Kedua}

Tahap kedua adalah menghitung nilai kritis chi-kuadrat $\left(\chi_{\text {kritis }}^{2}\right)$ berdasarkan tabel distribusi chi-kuadrat. Untuk menghitung nilai kritis chi-kuadrat, terlebih dahulu menghitung nilai derajat bebas.

$$
\text { Derajat bebas }=k-1 \text {. }
$$

Perhatikan bahwa $k$ merupakan jumlah sampel. Dalam hal ini, nilai $k=2$, sehingga derajat bebas $2-1=1$. Nilai kritis chikuadrat dengan derajat bebas 1 dan tingkat signifikansi $5 \%$ berdasarkan tabel distribusi chi-kuadrat adalah 3,841.

\section{Tahap Ketiga}

Tahap ketiga adalah menghitung nilai statistik dari uji McNemar. Berikut disajikan data dalam tabel kontingensi $2 \times 2$.

\section{Tabel 4.3}

\begin{tabular}{|c|c|c|c|}
\cline { 3 - 4 } \multicolumn{2}{c|}{} & \multicolumn{2}{c|}{ Sesudah Ada Iklan } \\
\cline { 3 - 4 } \multicolumn{2}{c|}{} & 0 & 1 \\
\hline \multirow{2}{*}{ Sebelum Ada Iklan } & 0 & 2 & 8 \\
\cline { 2 - 4 } & 1 & 1 & 4 \\
\hline
\end{tabular}

Berdasarkan Tabel 4.3, “0” menyatakan tidak menggunakan bumbu masakan merek A, sedangkan "1" menyatakan menggunakan bumbu masakan merek A. Diketahui terdapat 4 orang menggunakan bumbu masakan merek A sebelum dan setelah adanya iklan promosi. Terdapat 8 orang yang tidak menggunakan bumbu masakan merek A sebelum ada iklan 
promosi. Namun, setelah ada iklan promosi, maka 8 orang tersebut beralih untuk menggunakan bumbu masakan merek A.

Perhatikan bahwa $b+c \leq 20$, yakni $1+8 \leq 20$, maka nilai statistik dari uji McNemar $\left(T_{2}\right)$ dihitung dengan rumus sebagai berikut.

$$
T_{2}=2\left[\sum_{i=0}^{X}\left(\begin{array}{l}
n \\
i
\end{array}\right) p^{i} q^{n-i}\right]
$$

Diketahui $n=1+8=9$ dan $X=\min (1,8)=1$, sehingga

$$
\begin{gathered}
T_{2}=2\left[\sum_{i=0}^{X}\left(\begin{array}{c}
n \\
i
\end{array}\right) p^{i} q^{n-i}\right]=2[P(X=0)+P(X=1)] \\
=2\left[\left(\begin{array}{l}
9 \\
0
\end{array}\right)\left(\frac{1}{2}\right)^{0}\left(\frac{1}{2}\right)^{9}+\left(\begin{array}{l}
9 \\
1
\end{array}\right)\left(\frac{1}{2}\right)^{1}\left(\frac{1}{2}\right)^{8}\right] \\
=2[0,001953+0,017578]=0,039 .
\end{gathered}
$$

Berikut aturan pengambilan keputusan terhadap hipotesis.

Jika $T_{2} \geq \alpha$, maka $H_{0}$ diterima dan $H_{1}$ ditolak. Jika $T_{2}<\alpha$, maka $H_{1}$ diterima. dan $H_{0}$ ditolak.

Karena nilai $T_{2}$ lebih kecil dari tingkat signifikansi $\alpha=0,05$, maka hipotesis nol ditolak dan hipotesis alternatif diterima. Hal ini berarti terdapat pengaruh yang signifikan secara statistika pada penggunaan bumbu masakan mereka A, setelah adanya iklan promosi pada tingkat signifikansi 5\%. 


\section{KORELASI BERPERINGKAT} SPEARMAN

Korelasi berperingkat Spearman merupakan suatu nilai yang mengukur keeratan suatu hubungan antara dua buah variabel, di mana nilai tersebut dihitung berdasarkan data ranking yang diperoleh berdasarkan data asli dari masing-masing variabel. Pada korelasi Pearson, nilai korelasi dihitung dengan menggunakan data asli, sedangkan nilai korelasi berperingkat Spearman dihitung dengan menggunakan data ranking yang diperoleh berdasarkan data aslinya.Berikut rumus untuk menghitung korelasi berperingkat Spearman $\left(r_{s}\right)$.

$$
r_{s}=1-\frac{6 \sum_{i=1}^{n} D_{i}{ }^{2}}{(n)\left(n^{2}-1\right)}
$$

Perhatikan bahwa $r_{s}$ menyatakan nilai korelasi berperingkat Spearman, $D_{i}$ menyatakan nilai selisih dari pasangan nilai data ranking ke- $i$, dan $n$ menyatakan jumlah elemen dalam sampel. Setelah diperoleh nilai korelasi berperingkat Spearman (sampel), maka perlu diuji signifikansi dari korelasi berperingkat Spearman populasi $\left(\rho_{s}\right)$. Untuk menguji signifikansi dari korelasi berperingkat Spearman populasi, digunakan uji $t$. Berikut rumus untuk menghitung nilai statistik dari uji $t$. 


$$
t=\frac{r_{s} \sqrt{n-2}}{\sqrt{1-r_{s}^{2}}}
$$

Nilai statistik dari uji $t$ kemudian dibandingkan dengan dengan nilai kritis $t$ berdasarkan tabel distribusi $t$ untuk pengambilan keputusan terhadap hipotesis. Hipotesis nol menyatakan tidak terdapat hubungan yang signifikan secara statistika antara variabel pertama dan variabel kedua. Secara matematis dinyatakan

$$
H_{0}: \rho_{s}=0
$$

Hipotesis alternatif menyatakan terdapat hubungan yang signifikan secara statistika antara variabel pertama dan variabel kedua. Secara matematis dinyatakan

$$
H_{1}: \rho_{s} \neq 0
$$

Pengambilan keputusan terhadap hipotesis juga dapat dilakukan dengan pendekatan nilai probabilitas dari uji $t$. Nilai probabilitas dari uji $t$ dibandingkan dengan tingkat signifikansi yang digunakan $(\alpha)$. Berikut aturan pengambilan keputusan terhadap hipotesis berdasarkan pendekatan nilai probabilitas.

Jika nilai probabilitas $\geq \alpha$, maka $H_{0}$ diterima dan $H_{1}$ ditolak.

Jika nilai probabilitas $<\alpha$, maka $H_{0}$ ditolak dan $H_{1}$ diterima.

Sebagai contoh, misalkan seorang peneliti ingin mengukur keeratan hubungan antara jumlah jam belajar di luar waktu kuliah 
dalam sehari dan nilai indeks prestasi mahasiswa. Peneliti tersebut mengambil sampel sebanyak 12 orang mahasiswa dan kemudian melakukan interview untuk mengetahui informasi mengenai jumlah jam belajar di luar waktu kuliah dalam sehari dan nilai indeks prestasi mahasiswa. Berikut data yang telah diperoleh.

\section{Tabel 5.1 (Data Fiktif)}

\begin{tabular}{|c|c|c|c|c|c|c|c|c|c|c|c|c|}
\hline Mahasiswa & 1 & 2 & 3 & 4 & 5 & 6 & 7 & 8 & 9 & 10 & 11 & 12 \\
\hline$X$ & 2 & 4 & 0 & 5 & 7 & 7 & 9 & 8 & 6 & 5 & 2 & 9 \\
\hline$Y$ & 1,5 & 2,8 & 1,2 & 2,9 & 3,3 & 3,25 & 3,7 & 3,8 & 3,1 & 3,3 & 2 & 3,9
\end{tabular}

Berdasarkan Tabel 5.1, $X$ menyatakan jumlah jam belajar dalam sehari di luar waktu kuliah, sedangkan $Y$ menyatakan nilai indeks prestasi mahasiswa. Berikut akan diuji apakah terdapat hubungan yang signifikan antara jumlah jam belajar dalam sehari di luar waktu kuliah terhadap nilai indeks prestasi mahasiswa pada tingkat signifikansi 5\%.

\section{Tahap Pertama}

Tahap pertama adalah perumusan hipotesis. Berikut perumusan hipotesis.

$H_{0}: \rho_{s}=0$ atau tidak terdapat hubungan yang signifikan secara statistika antara jumlah jam belajar di luar waktu kuliah dalam sehari terhadap nilai indeks prestasi mahasiswa.

$H_{1}: \rho_{s} \neq 0$ atau terdapat hubungan yang signifikan secara statistika antara jumlah jam belajar di luar waktu kuliah dalam sehari terhadap nilai indeks prestasi mahasiswa. 


\section{Tahap Kedua}

Tahap kedua adalah menghitung nilai kritis $t$ berdasarkan tabel distribusi $t$. Sebelum menghitung nilai kritis $t$, terlebih dahulu menghitung nilai derajat bebas. Berikut rumus untuk menghitung nilai derajat bebas.

$$
\text { Derajat bebas }=n-2 \text {. }
$$

Perhatikan bahwa $n$ merupakan jumlah elemen dalam sampel, sehingga derajat bebas adalah $12-2=10$. Nilai kritis $t$ dengan derajat bebas 10 dan tingkat signifikansi $5 \%$ adalah $\pm 2,228$.

\section{Tahap Ketiga}

Tahap ketiga adalah menghitung nilai statistik dari uji $t$.

\section{Tabel 5.2}

\begin{tabular}{|c|c|c|c|c|c|c|c|c|c|c|c|c|}
\hline Mahasiswa & 1 & 2 & 3 & 4 & 5 & 6 & 7 & 8 & 9 & 10 & 11 & 12 \\
\hline$X$ & 2 & 4 & 0 & 5 & 7 & 7 & 9 & 8 & 6 & 5 & 2 & 9 \\
\hline$Y$ & 1,5 & 2,8 & 1,2 & 2,9 & 3,3 & 3,25 & 3,7 & 3,8 & 3,1 & 3,3 & 2 & 3,9 \\
\hline$R(X)$ & 2,5 & 4 & 1 & 5,5 & 8,5 & 8,5 & 11,5 & 10 & 7 & 5,5 & 2,5 & 11,5 \\
\hline$R(Y)$ & 2 & 4 & 1 & 5 & 8,5 & 7 & 10 & 11 & 6 & 8,5 & 3 & 12 \\
\hline$D=R(X)-R(Y)$ & 0,5 & 0 & 0 & 0,5 & 0 & 1,5 & 1,5 & -1 & 1 & -3 & $-0,5$ & $-0,5$ \\
\hline$D^{2}$ & 0,25 & 0 & 0 & 0,25 & 0 & 2,25 & 2,25 & 1 & 1 & 9 & 0,25 & 0,25 \\
\hline
\end{tabular}

Berdasarkan Tabel 5.2, $R(X)$ merupakan ranking dari nilai $X$, sedangkan $R(Y)$ merupakan ranking dari nilai $Y$.

$$
\begin{aligned}
& \sum_{i=1}^{n} D_{i}^{2}=0,25+0+0+\cdots+9+0,25+0,25=16,5 . \\
& \Rightarrow \quad \text { Urutkan nilai-nilai } X \text { dan } Y \text { dari yang terkecil hingga } \\
& \quad \text { terbesar (Tabel 5.3). }
\end{aligned}
$$




\section{Tabel 5.3}

\begin{tabular}{|c|c|c|c|c|c|c|c|c|c|c|c|c|}
\hline Urutan & 1 & 2 & 3 & 4 & 5 & 6 & 7 & 8 & 9 & 10 & 11 & 12 \\
\hline$X$ & 0 & 2 & 2 & 4 & 5 & 5 & 6 & 7 & 7 & 8 & 9 & 9 \\
\hline
\end{tabular}

Berdasarkan Tabel 5.3, nilai $X=0$ atau mahasiswa yang tidak pernah belajar berada pada urutan pertama. Mahasiswa yang belajar selama 6 jam atau $X=6$ berada pada urutan ketujuh. Terdapat dua orang mahasiswa yang belajar selama 5 jam atau $X=5$, yakni pada urutan kelima dan urutan keenam. Terdapat dua orang mahasiswa yang belajar selama 9 jam atau $X=9$, yakni pada urutan kesebelas dan urutan keduabelas, dan seterusnya.

\section{Tabel 5.4}

\begin{tabular}{|c|c|c|c|c|c|c|c|c|c|c|c|c|}
\hline Urutan & 1 & 2 & 3 & 4 & 5 & 6 & 7 & 8 & 9 & 10 & 11 & 12 \\
\hline$Y$ & 1,2 & 1,5 & 2 & 2,8 & 2,9 & 3,1 & 3,25 & 3,3 & 3,3 & 3,7 & 3,8 & 3,9 \\
\hline
\end{tabular}

Berdasarkan Tabel 5.4, mahasiswa dengan indeks prestasi 1,2 berada pada urutan pertama karena nilai tersebut paling kecil. Mahasiswa dengan indeks prestasi 3,9 terletak pada urutan keduabelas dengan urutan paling besar.

$\Rightarrow$ Selanjutnya memberi ranking untuk setiap nilai $X$ dan nilai $Y$. Nilai $X=2$ terdapat dua nilai, yakni pada urutan kedua dan urutan ketiga, sehingga ranking untuk nilai $X=2$ adalah

$$
\frac{2+3}{2}=2,5
$$


Nilai $X=7$ terdapat dua nilai, yakni pada urutan kedelapan dan urutan kesembilan, sehingga ranking untuk nilai $X=7$ adalah

$$
\frac{8+9}{2}=8,5
$$

Nilai $Y=3,3$ terdapat dua nilai, yakni urutan kedelapan dan urutan kesembilan, sehingga ranking untuk nilai $Y=3,3$ adalah

$$
\frac{8+9}{2}=8,5
$$

$\Rightarrow$ Kemudian menentukan nilai selisih untuk setiap pasangan nilai berdasarkan data ranking $X$ dan ranking $Y$. Nilai selisih tersebut misalkan dilambangkan dengan $D$. Sebagai contoh nilai $D$ untuk mahasiswa nomor 2 adalah $4-4=$ 0 . Nilai $D$ untuk mahasiswa nomor 8 adalah $10-11=$ -1 , dan seterusnya.

$\Rightarrow$ Menentukan nilai $D^{2}$. Sebagai contoh nilai $D^{2}$ dari mahasiswa nomor 8 adalah $(-1)^{2}=1$, nilai $D^{2}$ dari mahasiswa nomor 7 adalah $(1,5)^{2}=2,25$, dan seterusnya.

$\Rightarrow$ Menghitung koefisien korelasi berperingkat Spearman $\left(r_{s}\right)$. 


$$
\begin{gathered}
r_{s}=1-\frac{6 \sum_{i=1}^{n} D_{i}^{2}}{(n)\left(n^{2}-1\right)} \\
=1-\frac{(6)(15,5)}{(12)\left(12^{2}-1\right)} \\
=0,9458 .
\end{gathered}
$$

Nilai korelasi berperingkat Spearman $\left(r_{s}\right)$ berdasarkan perhitungan adalah 0,9458. Nilai tersebut dapat diinterpretasikan terdapat hubungan positif antara jumlah jam belajar dalam sehari di luar waktu kuliah dengan nilai indeks prestasi mahasiswa. Perhatikan bahwa nilai korelasi berperingat Spearman $\left(r_{s}\right)$ berkisar dari -1 sampai 1 .

$\Rightarrow$ Menghitung nilai statistik dari uji $t$.

$$
\begin{gathered}
t=\frac{r_{s} \sqrt{n-2}}{\sqrt{1-r_{s}^{2}}} \\
t=\frac{0,9458 \sqrt{12-2}}{\sqrt{1-0,9458^{2}}} \\
t=9,2098
\end{gathered}
$$

Nilai statistik dari uji $t$ berdasarkan perhitungan adalah 9,2098 . 


\section{Tahap Keempat}

Tahap keempat adalah pengambilan keputusan terhadap hipotesis.

Berikut daerah keputusan dengan nilai kritis $t= \pm 2,228$.

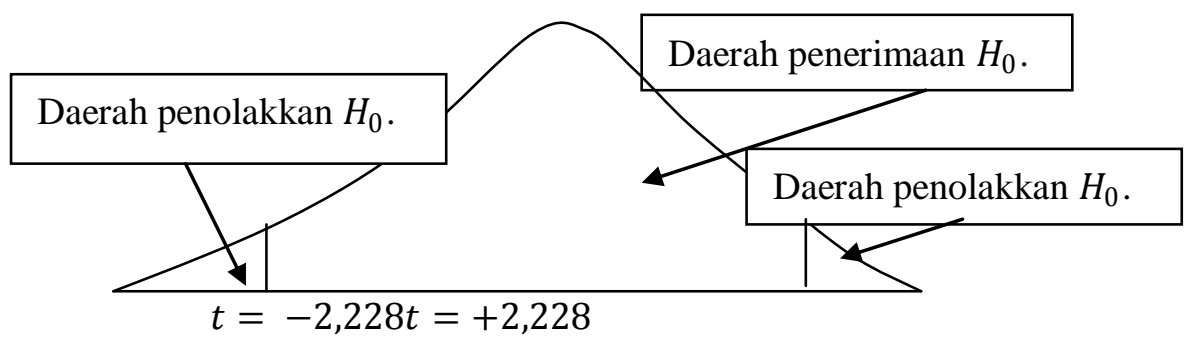

Jika $\left|t_{\text {hitung }}\right| \leq\left|t_{\text {kritis }}\right|$, maka $H_{0}$ diterima dan $H_{1}$ ditolak. Jika $\left|t_{\text {hitung }}\right|>\left|t_{\text {kritis }}\right|$, maka $H_{0}$ diolak dan $H_{1}$ diterima.

Berdasarkan perhitungan, nilai statistik dari uji $t$ adalah 9,2098. Karena nilai statistik dari uji $t$ berada di luar daerah penerimaan hipotesis nol, maka hipotesis nol ditolak dan hipotesis alternatif. Hal ini berarti terdapat hubungan yang signifikan secara statistika antara jumlah jam belajar di luar waktu kuliah dalam sehari dengan nilai indeks prestasi mahasiswa pada tingkat signifikansi $5 \%$. 


\section{UJI KRUSKAL-WALLIS}

Pada uji Mann-Whitney hanya menguji dua populasi independen, sedangkan pada uji Kruskal-Wallis menguji tiga atau lebih populasi independen. Tiga atau lebih sampel independen diuji apakah berasal dari populasi-populasi yang memiliki kesamaan rata-rata atau tidak. Uji Kruskal-Wallis merupakan alternatif dari analisis varians satu arah jika asumsi normalitas dari populasipopulasi yang diteliti tidak dipenuhi.

Hipotesis nol pada uji Kruskal-Wallis menyatakan tiga atau lebih sampel independen berasal dari populasi-populasi yang memiliki kesamaan rata-rata. Hipotesis alternatif menyatakan terdapat paling sedikit sepasang rata-rata populasi yang berbeda. Berikut rumus untuk menghitung nilai statistik dari uji Kruskal-Wallis $(H)$.

$$
H=\frac{12}{N(N+1)}\left[\frac{R_{1}^{2}}{n_{1}}+\frac{R_{2}^{2}}{n_{2}}+\cdots+\frac{R_{k}^{2}}{n_{k}}\right]-3(N+1) .
$$

Perhatikan bahwa $n_{i}$ menyatakan jumlah elemen sampel ke- $i, N$ menyatakan jumlah elemen dari seluruh sampel, yakni $N=n_{1}+$ $n_{2}+\cdots+n_{k}$, dan $R_{i}$ menyatakan jumlah ranking dari sampel ke$i$. Untuk pengambilan keputusan terhadap hipotesis, dapat dilakukan dengan membandingkan nilai statistik dari uji Kruskal- 
Wallis terhadap nilai kritis chi-kuadrat $\left(\chi_{\text {kritis }}^{2}\right)$. Berikut aturan pengambilan keputusan terhadap hipotesis.

$$
\begin{aligned}
& \text { Jika } H \leq \chi_{\text {kritis }}^{2} H_{0} \text { diterima dan } H_{1} \text { ditolak. } \\
& \text { Jika } H>\chi_{\text {kritis }}^{2}, H_{0} \text { ditolak dan } H_{1} \text { diterima. }
\end{aligned}
$$

Sebagai contoh kasus, misalkan seorang peneliti ingin meneliti kualitas (dalam penelitian ini, kualitas diukur berdasarkan jumlah siswa yang lulus PTN) dari tiga bimbingan belajar, yakni bimbingan belajar A, B, dan, C. Untuk keperluan penelitian, peneliti tersebut melakukan observasi untuk memperoleh data mengenai jumlah siswa yang lulus untuk masuk perguruan tinggi negeri selama 6 tahun terakhir. Berikut data mengenai jumlah siswa yang lulus untuk masuk perguruan tinggi negeri dari ketiga bimbingan belajar A,B, dan C selama 6 tahun terakhir.

\section{Tabel 6.1 (Data Fiktif)}

\begin{tabular}{|c|c|c|c|c|c|c|}
\hline Tahun & 2000 & 2001 & 2002 & 2003 & 2004 & 2005 \\
\hline Bimbe1 A & 50 & 70 & 65 & 60 & 70 & 45 \\
\hline Bimbe1 B & 80 & 69 & 50 & 65 & 65 & 45 \\
\hline Bimbe1 C & 80 & 85 & 90 & 120 & 150 & 200 \\
\hline
\end{tabular}

Berdasarkan data pada Tabel 6.1, misalkan diasumsikan jumlah siswa yang belajar dari masing-masing bimbingan belajar adalah sama (misalkan 300 siswa) untuk setiap tahun. Jadi, pada tahun 2000, siswa yang lulus untuk masuk perguruan tinggi negeri dari bimbingan belajar A sebanyak 50 siswa dari 300 siswa, bimbingan belajar B sebanyak 80 siswa dari 300 siswa, dan bimbingan belajar $\mathrm{C}$ sebanyak 80 siswa dari 300 siswa. 
Pada tahun 2005, siswa yang lulus untuk masuk perguruan tinggi negeri dari bimbingan belajar A sebanyak 45 siswa dari 300 siswa, bimbingan belajar B sebanyak 45 siswa dari 300 siswa, dan bimbingan belajar C sebanyak 200 siswa dari 300 siswa. Berikut akan diuji apakah terdapat perbedaan yang signifikan secara statistika mengenai kualitas di antara bimbingan belajar A, B, dan C pada tingkat signifikansi 5\%.

\section{Tahap Pertama}

Tahap pertama adalah perumusan hipotesis. Berikut perumusan hipotesis.

$H_{0}: \mu_{1}=\mu_{2}=\mu_{3}$ atau rata-rata jumlah siswa yang lulus dari ketiga bimbingan belajar adalah sama atau ketiga bimbingan belajar mempunyai kualitas yang sama.

$H_{1}$ : Terdapat perbedaan rata-rata mengenai jumlah siswa yang lulus di antara ketiga bimbingan belajar atau terdapat perbedaan kualitas di antara ketiga bimbingan belajar.

\section{Tahap Kedua}

Tahap kedua adalah menghitung nilai kritis chi-kuadrat berdasarkan tabel distribusi chi-kuadrat. Sebelum menghitung nilai kritis chi-kuadrat, terlebih dahulu menghitung nilai derajat bebas. Berikut rumus untuk menghitung nilai derajat bebas.

$$
\text { Derajat bebas }=k-1 \text {. }
$$


Perhatikan bahwa $k$ merupakan jumlah sampel, sehingga nilai derajat bebas adalah $3-1=2$. Nilai kritis chi-kuadrat dengan derajat bebas 2 dan tingkat signifikansi 5\% adalah 5,991. Nilai kritis chi-kuadrat dapat dihitung dengan Microsoft Excel sebagai berikut.

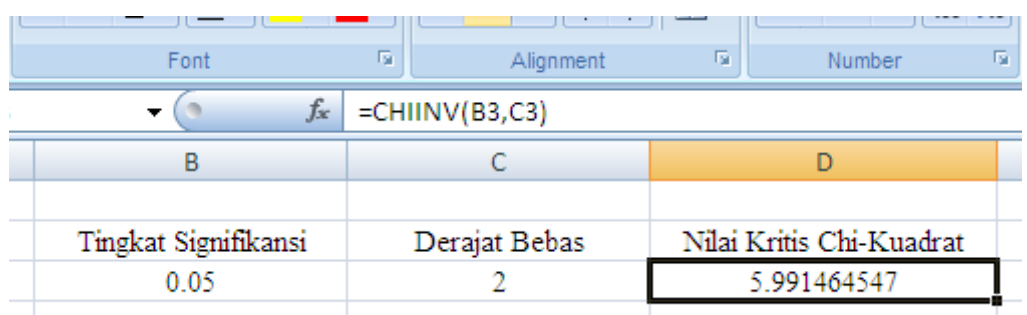

Gambar 6.1

\section{Tahap Ketiga}

Tahap ketiga adalah menghitung nilai statistik dari uji KruskalWallis $(H)$.

\section{Tabel1.24}

\begin{tabular}{|c|c|c|c|c|c|c|c|c|}
\hline Tahum & 2000 & 2001 & 2002 & 2003 & 2004 & 2005 & Total Ranking & $\begin{array}{c}\text { Rata-Rata } \\
\text { Ranking }\end{array}$ \\
\hline Ranking Bimbel A & 3,5 & 10,5 & 7 & 5 & 10,5 & 1,5 & 38 & 6,33 \\
\hline Ranking Bimbel B & 12,5 & 9 & 3,5 & 7 & 7 & 1,5 & 40,5 & 6,5 \\
\hline Ranking BimbelC & 12,5 & 14 & 15 & 16 & 17 & 18 & 92,5 & 15,42 \\
\hline
\end{tabular}

$\Rightarrow$ Gabungkan nilai data dari seluruh sampel (Tabel 6.3).

\section{Tabel 6.3}

\begin{tabular}{|c|c|c|c|c|c|}
\hline 50 & 70 & 65 & 60 & 70 & 45 \\
\hline 80 & 69 & 50 & 65 & 65 & 45 \\
\hline 80 & 85 & 90 & 120 & 150 & 200 \\
\hline
\end{tabular}


$\Rightarrow$ Urutkan nilai data dari yang paling kecil sampai yang paling besar (Tabel 6.4).

Tabel 6.4

\begin{tabular}{|c|c|c|c|c|c|c|c|c|c|}
\hline Urutan & 1 & 2 & 3 & 4 & 5 & 6 & 7 & 8 & 9 \\
\hline Jumlah Mahasiswa & 45 & 45 & 50 & 50 & 60 & 65 & 65 & 65 & 69 \\
\hline Urutan & 10 & 11 & 12 & 13 & 14 & 15 & 16 & 17 & 18 \\
\hline Jumlah Mahasiswa & 70 & 70 & 80 & 80 & 85 & 90 & 120 & 150 & 200 \\
\hline
\end{tabular}

Perhatikan bahwa nilai 45 merupakan nilai yang paling kecil. Karena nilai 45 terdapat 2 nilai, maka nilai 45 berada pada urutan pertama dan urutan kedua.

$\Rightarrow$ Beri ranking untuk setiap nilai. Sebagai contoh, nilai 45 terdapat dua nilai, yakni pada urutan pertama dan urutan kedua, sehingga ranking untuk nilai 45 adalah

$$
\frac{1+2}{2}=1,5
$$

Nilai 65 terdapat tiga nilai, yakni pada urutan keenam, ketujuh, dan kedelapan, sehingga ranking untuk nilai 65 adalah

$$
\frac{6+7+8}{3}=7
$$

$\Rightarrow$ Selanjutnya menghitung nilai statistik dari uji KruskalWallis $(H)$.

$$
H=\frac{12}{N(N+1)}\left[\frac{R_{1}^{2}}{n_{1}}+\frac{R_{2}^{2}}{n_{2}}+\cdots+\frac{R_{k}^{2}}{n_{k}}\right]-3(N+1)
$$




$$
\begin{gathered}
H=\frac{12}{18(18+1)}\left[\frac{38^{2}}{6}+\frac{40,5^{2}}{6}+\frac{92,5^{2}}{6}\right]-3(18+1) \\
H=11,073 .
\end{gathered}
$$

\section{Tahap Keempat}

Tahap keempat adalah pengambilan keputusan terhadap hipotesis.

Berikut aturan dalam pengambilan keputusan terhadap hipotesis.

$$
\begin{aligned}
& \text { Jika } H \leq \chi_{\text {kritis }}^{2}, H_{0} \text { diterima dan } H_{1} \text { ditolak. } \\
& \text { Jika } H>\chi_{\text {kritis }}^{2}, H_{0} \text { ditolak dan } H_{1} \text { diterima. }
\end{aligned}
$$

Diketahui nilai statistik dari uji Kruskal-Wallis adalah 11,073 dan nilai kritis chi-kuadrat adalah 5,991. Karena nilai statistik dari uji Kruskal-Wallis lebih besar dari nilai kritis chi-kuadrat, maka hipotesis nol ditolak dan hipotesis alternatif diterima. Hal ini berarti terdapat perbedaan kualitas di antara ketiga bimbingan belajar tersebut pada tingkat signifikansi $5 \%$. 


\section{UJI COCHRAN}

Uji Cochran merupakan perluasan dari uji McNemar. Pada uji McNemar hanya menguji dua populasi berpasangan, sedangkan pada uji Cochran dapat menguji tiga atau lebih populasi berhubungan. Pada uji Cochran, sekelompok subjek penelitian (misalkan sekelompok orang) dikenai tiga atau lebih perlakuan yang berbeda. Masing-masing subjek penelitian hanya memiliki dua macam penilaian (dichotomous outcomes) untuk setiap perlakuan yang diberikan. Dua penilaian tersebut bersifat saling berlawanan atau dikotomi. Contoh dari dua penilaian yang bersifat saling berlawanan, yakni "benar atau salah", "sukses atau gagal", "ikut atau tidak ikut", "datang atau tidak datang", "sulit atau tidak sulit”, dan sebagainya (Conover, 1999:250-251).

Hipotesis nol pada uji Cochran menyatakan seluruh perlakuan memberikan efek atau pengaruh yang sama (tidak terdapat perbedaan yang signifikan secara statistika). Hipotesis alternatif menyatakan terdapat perbedaan efek atau pengaruh di antara perlakuan-perlakuan yang diberikan (terdapat perbedaan yang signifikan secara statistika). Berikut rumus untuk menghitung nilai statistik dari uji Cochran $(Q)$. 


$$
Q=\frac{k(k-1) \sum_{j=1}^{k} C_{j}^{2}-(k-1)\left(\sum_{j=1}^{k} C_{j}\right)^{2}}{k\left(\sum_{j=1}^{k} C_{j}\right)-\sum_{i=1}^{n} R_{i}^{2}} .
$$

Perhatikan bahwa $k$ menyatakan jumlah perlakuan, $C_{j}$ menyatakan banyak nilai 1 pada perlakuan ke-j, dan $R_{i}$ menyatakan banyaknya nilai 1 pada subjek penelitian ke-i (lihat Tabel 7.2). Untuk pengambilan keputusan terhadap hipotesis, dapat dilakukan dengan membandingkan nilai statistik dari uji Cochran terhadap nilai kritis chi-kuadrat $\left(\chi_{\text {kritis }}^{2}\right)$. Berikut aturan dalam pengambilan keputusan terhadap hipotesis.

$$
\begin{aligned}
& \text { Jika } Q \leq \chi_{\text {kritis }}^{2}, H_{0} \text { diterima dan } H_{1} \text { ditolak. } \\
& \text { Jika } Q>\chi_{\text {kritis }}^{2}, H_{0} \text { ditolak dan } H_{1} \text { diterima. }
\end{aligned}
$$

Pengambilan keputusan terhadap hipotesis juga dapat dilakukan dengan pendekatan nilai probabilitas dari uji Cochran. Nilai probabilitas dari uji Cochran dibandingkan dengan tingkat signifikansi yang digunakan $(\alpha)$. Berikut aturan pengambilan keputusan terhadap hipotesis berdasarkan nilai probabilitas.

Jika nilai probabilitas $\geq \alpha$, maka $H_{0}$ diterima dan $H_{1}$ ditolak.

Jika nilai probabilitas $<\alpha$, maka $H_{0}$ ditolak dan $H_{1}$ diterima.

Sebagai contoh kasus, misalkan seorang produsen kerupuk ingin memasarkan kerupuk dengan empat rasa, yakni rasa ayam, daging, ikan, dan udang ke kota B. Sebelum memasarkan kerupuk-kerupuk tersebut ke kota $\mathrm{B}$, produsen tersebut ingin 
mengetahui respon atau penilaian dari masyarakat yang tinggal di sekitar rumahnya terhadap keempat rasa kerupuk tersebut. Misalkan respon yang digunakan berupa "suka" atau "tidak suka". Untuk keperluan penelitian, produsen tersebut mempersilahkan 11 orang untuk mencicipi keempat rasa kerupuk tersebut dan memberikan penilaian atau respon terhadap keempat rasa kerupuk tersebut. Berikut data yang telah dikumpulkan oleh produsen kerupuk tersebut (Tabel 7.1).

\section{Tabel 7.1}

\begin{tabular}{|c|c|c|c|c|c|}
\hline \multirow{2}{*}{ No } & \multirow{2}{*}{ Nama } & \multicolumn{5}{|c|}{ Kerupuk rasa } \\
\cline { 3 - 6 } & & Ayam & Daging & Ikan & Udang \\
\hline 1 & ugi & 1 & 0 & 0 & 0 \\
\hline 2 & ulan & 1 & 1 & 1 & 1 \\
\hline 3 & evelin & 0 & 0 & 0 & 0 \\
\hline 4 & hasoloan & 0 & 1 & 1 & 1 \\
\hline 5 & fitri & 1 & 1 & 1 & 1 \\
\hline 6 & suci & 1 & 0 & 0 & 1 \\
\hline 7 & mifdhal & 1 & 0 & 1 & 1 \\
\hline 8 & hanafi & 1 & 0 & 0 & 1 \\
\hline 9 & iqbal & 1 & 0 & 0 & 0 \\
\hline 10 & ridho & 1 & 0 & 0 & 0 \\
\hline 11 & romi & 1 & 1 & 1 & 1 \\
\hline
\end{tabular}

Berdasarkan Tabel 7.1, respon 0 menyatakan tidak suka, sedangkan respon 1 menyatakan suka.Diketahui seorang subjek yang bernama Ugi hanya menyukai kerupuk rasa ayam. Subjek yang bernama Ulan menyukai keempat rasa kerupuk. Subjek yang bernama Suci hanya menyukai kerupuk rasa ayam dan udang. Berikut akan diuji apakah keempat rasa kerupuk tersebut memberikan kepuasan yang sama bagi responden. 


\section{Tahap Pertama}

Tahap pertama adalah perumusan hipotesis. Berikut perumusan hipotesis.

$H_{0}$ : Keempat jenis kerupuk memberikan kepuasan rasa yang sama.

$H_{1}$ : Paling tidak terdapat satu rasa kerupuk yang memberikan kepuasan rasa berbeda di antara rasa kerupuk lainnya.

\section{Tahap Kedua}

Tahap kedua adalah menghitung nilai kritis chi-kuadrat berdasarkan tabel distribusi chi-kuadrat. Sebelum menghitung nilai kritis chi-kuadrat, terlebih dahulu menghitung nilai derajat bebas. Berikut rumus untuk menghitung nilai derajat bebas.

$$
\text { Derajat bebas }=k-1 \text {. }
$$

Perhatikan bahwa $k$ merupakan jumlah perlakuan, sehingga derajat bebas adalah $4-1=3$. Nilai kritis chi-kuadrat dengan derajat bebas 3 dan tingkat signifikansi 5\% adalah 7,815. Perhitungan nilai kritis chi-kuadrat juga dapat dihitung dengan Microsoft Excel sebagai berikut. 


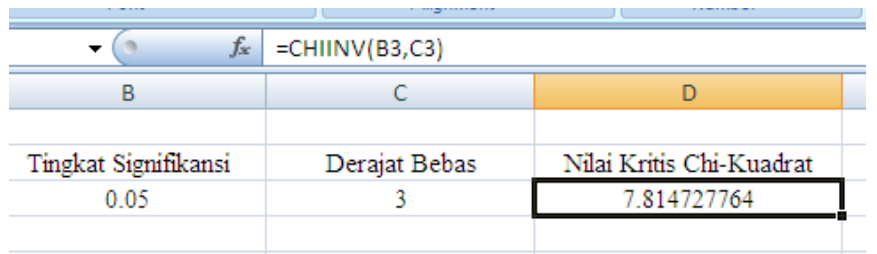

\section{Gambar 7.1}

\section{Tahap Ketiga}

Tahap ketiga adalah menghitung nilai statistik dari uji Cochran $(Q)$.

$\Rightarrow$ Subjek yang memberikan penilaian yang sama terhadap keempat rasa kerupuk tidak diikutkan dalam analisis (lihat Tabel 7.2). Sebagai contoh pada baris ketiga, subjek yang bernama Evelin (lihat Tabel 7.2) memberikan penilaian yang sama terhadap empat jenis rasa kerupuk, yakni 0,0,0,0, sehingga subjek tersebut tidak diikutkan dalam analisis. Begitu juga dengan subjek yang bernama Fitri memberikan penilaian yang sama terhadap empat jenis rasa kerupuk, yakni 1,1,1,1, sehingga subjek tersebut tidak diikutkan dalam analisis. Subjek nomor 2,3, dan 5 tidak diikutsertakan dalam analisis, karena memberikan penilaian yang sama terhadap empat jenis rasa kerupuk, yakni $(1,1,1,1)$ atau $(0,0,0,0)$.

\section{Tabel 7.2}




\begin{tabular}{|c|c|c|c|c|c|c|c|}
\hline \multirow[b]{2}{*}{ No } & \multirow[b]{2}{*}{ Nama } & \multicolumn{4}{|c|}{ Kerupuk rasa } & \multirow[b]{2}{*}{$R$} & \multirow[b]{2}{*}{$R^{2}$} \\
\hline & & Ayam & Daging & Ikan & Udang & & \\
\hline 1 & Ugi & 1 & 0 & 0 & 0 & 1 & 1 \\
\hline 4 & Hasoloan & 0 & 1 & 1 & 1 & 3 & 9 \\
\hline 6 & Suci & 1 & 0 & 0 & 1 & 2 & 4 \\
\hline 7 & Mifdhal & 1 & 0 & 1 & 1 & 3 & 9 \\
\hline 8 & Hanafi & 1 & 0 & 0 & 1 & 2 & 4 \\
\hline 9 & Iqbal & 1 & 0 & 0 & 0 & 1 & 1 \\
\hline 10 & Ridho & 1 & 0 & 0 & 0 & 1 & 1 \\
\hline total & & $C_{1}=6$ & $C_{2}=1$ & $C_{2}=2$ & $C_{4}=4$ & 13 & 29 \\
\hline
\end{tabular}

$\Rightarrow$ Menghitung nilai statistik dari uji Cochran $(Q)$.

$$
\begin{gathered}
Q=\frac{k(k-1) \sum_{j=1}^{k} C_{j}^{2}-(k-1)\left(\sum_{j=1}^{k} C_{j}\right)^{2}}{k\left(\sum_{j=1}^{k} C_{j}\right)-\sum_{i=1}^{n} R_{i}^{2}} \\
Q=\frac{4(4-1)\left(6^{2}+1^{2}+2^{2}+4^{2}\right)-(4-1)(13)^{2}}{(4)(13)-(29)} \\
=7,695 \text { atau } 7,70
\end{gathered}
$$

\section{Tahap Keempat}

Tahap keempat adalah pengambilan keputusan terhadap hipotesis.

Berikut aturan dalam pengambilan keputusan terhadap hipotesis.

Jika $Q \leq \chi_{\text {kritis }}^{2}, H_{0}$ diterima dan $H_{1}$ ditolak. Jika $Q>\chi_{\text {kritis }}^{2}, H_{0}$ ditolak dan $H_{1}$ diterima.

Perhatikan bahwa karena nilai statistik dari uji Cochran, yakni 7,70, lebih kecil dari nilai kritis chi-kuadrat, yakni, 7,815, maka hipotesis nol diterima dan hipotesis alternatif ditolak. Hal ini berarti keempat jenis kerupuk memberikan kepuasan rasa yang sama pada tingkat signifikansi $5 \%$. 


\section{UJI FRIEDMAN}

Pada pembahasan sebelumnya telah dibahas mengenai uji Wilcoxon. Uji Wilcoxon hanya dapat menguji dua populasi berpasangan, sedangkan pada uji Friedman dapat menguji tiga atau lebih populasi berpasangan (Conover, 1999:368). Dalam uji Friedman, sekelompok subjek penelitian dikenai tiga atau lebih perlakuan yang berbeda. Masing-masing subjek penelitian memberikan penilaian terhadap masing-masing perlakuan yang diberikan. Selanjutnya penilaian dari masing-masing subjek diberi ranking. Pemberian ranking dimulai dari 1 sampai $k$, di mana $k$ merupakan banyaknya perlakuan. Perhatikan bahwa karena data yang dianalisis berupa data ranking, maka data tersebut termasuk data ordinal.Hipotesis nol pada uji Friedman menyatakan tidak terdapat perbedaan atau pengaruh (yang signifikan secara statistika) di antara perlakuan-perlakuan (treatment) yang 
diberikan.Hipotesis alternatif menyatakan terdapat paling tidak satu perlakuan yang memberikan pengaruh berbeda (signifikan secara statistika) dari perlakuan lainnya. Berikut rumus untuk menghitung nilai statistik dari uji Friedman $S$.

$$
S=\left[\frac{12}{b k(k+1)} \sum_{i=1}^{k}\left(R_{i}^{2}\right)\right]-3 b(k+1) .
$$

Perhatikan bahwa $b$ menyatakan jumlah subjek atau jumlah baris, dan $k$ menyatakan jumlah perlakuan atau jumlah kolom. Untuk pengambilan keputusan terhadap hipotesis, dapat dibandingkan nilai statistik dari dari uji Friedman terhadap nilai kritis chi$\operatorname{kuadrat}\left(\chi_{\text {kritis }}^{2}\right)$. Berikut aturan pengambilan keputusan terhadap hipotesis.

$$
\begin{aligned}
& \text { Jika } S \leq \chi_{\text {kritis }}^{2}, H_{0} \text { diterima dan } H_{1} \text { ditolak. } \\
& \text { Jika } S>\chi_{\text {kritis }}^{2}, H_{0} \text { ditolak dan } H_{1} \text { diterima. }
\end{aligned}
$$

Sebagai contoh kasus, misalkan seorang produsen kerupuk ingin memasarkan kerupuk dengan empat rasa, yakni rasa ayam, daging, ikan, dan udang ke kota B. Sebelum memasarkan kerupuk-kerupuk tersebut, produsen tersebut ingin mengetahui respon dari masyarakat yang tinggal di sekitar rumahnya, terhadap keempat rasa kerupuk tersebut. Respon tersebut berupa nilai yang diberikan oleh masyarakat. Nilai tersebut berkisar dari 10 sampai 100. Produsen tersebut mempersilahkan 12 orang responden untuk mencicipi keempat rasa kerupuk tersebut dan memberikan penilaian atau respon dari keempat rasa kerupuk tersebut. Data 
diberikan pada Tabel 8.1. Berdasarkan data pada Tabel 8.1, subjek bernama Ugi memberi nilai 90 terhadap kerupuk rasa ayam, nilai 85 terhadap kerupuk rasa daging, nilai 83 terhadap kerupuk rasa ikan, dan nilai 70 terhadap kerupuk rasa udang. Pada tingkat signifikansi 5\%, berikut akan diuji apakah keempat rasa kerupuk tersebut memberikan kepuasan yang sama.

\section{Tabel 8.1 (Data Fiktif)}

\begin{tabular}{|c|c|c|c|c|c|}
\hline \multirow{2}{*}{ No. } & \multirow{2}{*}{ Nama } & \multicolumn{4}{|c|}{ Kerupuk rasa } \\
\cline { 3 - 6 } & Ayam & Daging & Ikan & Udang \\
\hline 1 & ugi & 90 & 85 & 83 & 70 \\
\hline 2 & ulan & 90 & 70 & 77 & 65 \\
\hline 3 & evelin & 75 & 70 & 60 & 85 \\
\hline 4 & hasoloan & 80 & 70 & 75 & 90 \\
\hline 5 & fitri & 90 & 85 & 60 & 89 \\
\hline 6 & suci & 60 & 65 & 70 & 85 \\
\hline 7 & mifdha1 & 65 & 85 & 70 & 90 \\
\hline 8 & hanafi & 65 & 100 & 60 & 85 \\
\hline 9 & iqba1 & 80 & 70 & 75 & 90 \\
\hline 10 & ridho & 90 & 70 & 80 & 75 \\
\hline 11 & Romi & 75 & 65 & 70 & 64 \\
\hline 12 & alan & 80 & 70 & 75 & 90 \\
\hline
\end{tabular}

\section{Tahap Pertama}

Tahap pertama adalah perumusan hipotesis. Berikut perumusan hipotesis.

$H_{0}$ : Keempat jenis kerupuk memberikan kepuasan rasa yang sama (perbedaan yang terjadi tidak signifikan secara statistika).

$H_{1}$ : Paling tidak terdapat satu rasa kerupuk yang memberikan kepuasan rasa berbeda di antara rasa kerupuk lainnya (terdapat perbedaan yang signifikan secara statistika) 


\section{Tahap Kedua}

Tahap kedua adalah menghitung nilai kritis chi-kuadrat $\left(\chi_{\text {kritis }}^{2}\right)$ berdasarkan tabel distribusi chi-kuadrat. Sebelum menghitung nilai kritis chi-kuadrat, terlebih dahulu menghitung nilai derajat bebas. Berikut rumus untuk menghitung nilai derajat bebas.

$$
\text { Derajat bebas }=k-1 \text {. }
$$

Perhatikan bahwa $k$ merupakan jumlah perlakuan, sehingga derajat bebas adalah $4-1=3$. Nilai kritis chi-kuadrat dengan derajat bebas 3 dan tingkat signifikansi 5\% adalah 7,815. Perhitungan nilai kritis juga dapat dihitung dengan Microsoft Excel sebagai berikut.

\begin{tabular}{c|c|c|}
\hline \multicolumn{1}{c|}{$f_{\boldsymbol{x}}$} & $=\mathrm{CHINV}(\mathrm{B} 3, \mathrm{C} 3)$ \\
\hline \hline B & $\mathrm{C}$ & \\
\hline & & \\
\hline Tingkat Signifikansi & Derajat Bebas & Nilai Kritis Chi-Kuadrat \\
\hline 0.05 & 3 & 7.814727764 \\
\hline & & \\
\hline
\end{tabular}

\section{Gambar 8.1}

\section{Tahap Ketiga}

Tahap ketiga adalah menghitung nilai statistik dari uji Friedman $(S)$.

Tabel 8.2 


\begin{tabular}{|c|c|c|c|c|c|}
\hline \multirow{2}{*}{ No. } & \multirow{2}{*}{ Nama } & \multicolumn{5}{|c|}{ Kerupuk rasa } \\
\cline { 3 - 6 } & Ayam & Daging & Ikan & Udang \\
\hline 1 & ugi & 4 & 3 & 2 & 1 \\
\hline 2 & ulan & 4 & 2 & 3 & 1 \\
\hline 3 & evelin & 3 & 2 & 1 & 4 \\
\hline 4 & hasoloan & 3 & 1 & 2 & 4 \\
\hline 5 & fitri & 4 & 2 & 1 & 3 \\
\hline 6 & suci & 1 & 2 & 3 & 4 \\
\hline 7 & mifdhal & 1 & 3 & 2 & 4 \\
\hline 8 & hanafi & 2 & 4 & 1 & 3 \\
\hline 9 & iqbal & 3 & 1 & 2 & 4 \\
\hline 10 & ridho & 4 & 1 & 3 & 2 \\
\hline 11 & Romi & 4 & 2 & 3 & 1 \\
\hline 12 & alan & 3 & 1 & 2 & 4 \\
\hline \multicolumn{2}{|l|}{ jumlah ranking } & 36 & 24 & 25 & 35 \\
\hline \multicolumn{2}{|l}{ rata-rata ranking } & 3 & 2 & 2,083333 & 2,916667 \\
\hline
\end{tabular}

$\Rightarrow$ Berdasarkan data pada Tabel 8.2, setiap subjek atau orang dikenai empat perlakuan, yakni setiap subjek harus mencicipi empat rasa kerupuk. Kemudian subjek tersebut memberi nilai terhadap empat rasa kerupuk tersebut. Sebagai contoh nilai-nilai yang diberikan Ugi terhadap empat rasa kerupuk tersebut adalah 90, 85, 83, 70. Kemudian nilai-nilai tersebut diberi ranking. Karena jumlah perlakuan sebanyak 4 , maka nilai ranking dimulai dari 1 sampai 4. Nilai yang paling kecil diberi ranking 1 dan nilai yang paling besar diberi ranking 4. Nilai-nilai yang diberikan oleh Ugi adalah 90,85, 83, dan 70. Nilai yang paling kecil adalah 70, sehingga nilai 70 diberi nilai ranking 1, 83 diberi nilai ranking 2, nilai 85 diberi nilai ranking 3, dan nilai 90 diberi nilai ranking 4 .

$\Rightarrow$ Jika terdapat nilai-nilai yang sama, misalkan Ugi memberi nilai 70,80,70, dan 90, maka nilai 70 diberi ranking 1,5, 
nilai 80 diberi ranking 3, dan nilai 90 diberi ranking 4 . Nilai 70 merupakan nilai paling kecil, disusul dengan nilai 80, dan nilai 90.

Tabel 8.3

\begin{tabular}{|c|c|c|c|}
\hline Urutan ke-1 & Urutan ke-2 & Urutan ke-3 & Urutan ke-4 \\
\hline 70 & 70 & 80 & 90 \\
\hline
\end{tabular}

Nilai 70 terdapat dua nilai, yakni pada urutan pertama dan urutan kedua, sehingga ranking untuk nilai 70 adalah

$$
\frac{1+2}{2}=1,5
$$

Contoh lain misalkan Ugi memberi nilai 80,70,80, dan 90. Maka nilai 70 diberi ranking 1, nilai 80 diberi ranking 2,5, dan nilai 90 diberi ranking 4. Nilai 70 merupakan nilai paling kecil, disusul dengan nilai 80, dan nilai 90.

\section{Tabel 8.4}

\begin{tabular}{|c|c|c|c|}
\hline Urutan ke-1 & Urutan ke-2 & Urutan ke-3 & Urutan ke-4 \\
\hline 70 & 80 & 80 & 90
\end{tabular}

Nilai 80 terdapat dua nilai, yakni pada urutan kedua dan urutan ketiga, sehingga ranking untuk nilai 80 adalah

$$
\frac{2+3}{2}=2,5
$$

$\Rightarrow$ Menjumlahkan nilai ranking dari masing-masing perlakuan. Berdasarkan data pada Tabel 8.2, jumlah 
ranking untuk perlakuan kerupuk rasa ayam adalah 36, jumlah ranking untuk perlakuan kerupuk rasa daging adalah 24, jumlah ranking untuk perlakuan kerupuk rasa ikan adalah 25, dan jumlah ranking untuk perlakuan kerupuk rasa udang 35 .

$\Rightarrow$ Menghitung nilai statistik dari uji Friedman $(S)$.

$$
\begin{gathered}
S=\left[\frac{12}{b k(k+1)} \sum_{i=1}^{k}\left(R_{i}^{2}\right)\right]-3 b(k+1) \\
\left.=\frac{12}{(12 \times 4)(4+1)}\left(36^{2}+24^{2}+25^{2}+35^{2}\right)\right] \\
-(3 \times 12)(4+1) \\
=6,1 .
\end{gathered}
$$

\section{Tahap Keempat}

Tahap keempat adalah pengambilan keputusan terhadap hipotesis. Berikut aturan dalam pengambilan keputusan terhadap hipotesis.

$$
\begin{aligned}
& \text { Jika } S \leq \chi_{\text {kritis }}^{2}, H_{0} \text { diterima dan } H_{1} \text { ditolak. } \\
& \text { Jika } S>\chi_{\text {kritis }}^{2}, H_{0} \text { ditolak dan } H_{1} \text { diterima. }
\end{aligned}
$$

Perhatikan bahwa jarena nilai statistik dari uji Friedman, yakni 6,1, lebih kecil dari nilai kritis chi-kuadrat, yakni 7,815, maka hipotesis nol diterima dan hipotesis alternatif ditolak. Hal ini berarti keempat jenis kerupuk memberikan kepuasan rasa yang sama. 


\section{UJI CHI-KUADRAT}

Uji chi-kuadrat (goodness of fit) merupakan suatu uji yang digunakan untuk menguji kesesuaian atau kecocokkan antara distribusi data berdasarkan pengamatan dengan distribusi data berdasarkan teoritis. Dengan kata lain, uji chi-kuadrat menguji kesesuaian antara frekuensi pengamatan dengan frekuensi harapan. Hipotesis nol pada uji chi-kuadrat menyatakan terjadi kesesuaian antara frekuensi pengamatan dengan frekuensi harapan. Sedangkan hipotesis alternatif menyatakan frekuensi pengamatan berbeda dengan frekuensi harapan. Berikut rumus untuk menghitung nilai statistik dari uji chi-kuadrat $\left(\chi_{\text {hitung }}^{2}\right)$.

$$
\chi_{\text {hitung }}^{2}=\frac{\sum\left(f_{p}-f_{h}\right)^{2}}{f_{h}} .
$$


Perhatikan bahwa $f_{p}$ merupakan frekuensi pengamatan (observed frequency), sedangkan $f_{h}$ merupakan frekuensi harapan (expected frequency). Untuk pengambilan keputusan terhadap hipotesis, dapat dilakukan dengan membandingkan nilai statistik dari uji chi-kuadratterhadap nilai kritis chi-kuadrat $\left(\chi_{\text {kritis }}^{2}\right)$. Berikut aturan pengambilan keputusan terhadap hipotesis.

$$
\begin{aligned}
& \text { Jika } \chi_{\text {hitung }}^{2} \leq \chi_{\text {kritis }}^{2}, H_{0} \text { diterima dan } H_{1} \text { ditolak. } \\
& \text { Jika } \chi_{\text {hitung }}^{2}>\chi_{\text {kritis }}^{2}, H_{0} \text { ditolak dan } H_{1} \text { diterima. }
\end{aligned}
$$

Pengambilan keputusan terhadap hipotesis juga dapat dilakukan dengan pendekatan nilai probabilitas dari uji chi-kuadrat. Nilai probabilitas tersebut dibandingkan dengan tingkat signifikansi yang digunakan $\left(\chi_{\text {kritis }}^{2}\right)$. Berikut aturan pengambilan keputusan terhadap hipotesis berdasarkan nilai probabilitas.

Jika nilai probabilitas $\geq \chi_{\text {kritis }}^{2}$, maka $H_{0}$ diterima dan $\mathrm{H}_{1}$ ditolak.

Jika nilai probabilitas $<\chi_{\text {kritis }}^{2}$, maka $H_{0}$ ditolak dan $\mathrm{H}_{1}$ diterima.

\section{Contoh Kasus 1}

Sekeping koin terdiri dari dua sisi, yakni angka dan gambar. Misalkan koin tersebut dilempar sebanyak 100 kali. Secara teoritis, probabilitas untuk muncul sisi angka adalah $\frac{1}{2}$ dan probabilitas untuk muncul sisi gambar adalah $\frac{1}{2}$, sehingga dalam 100 kali lemparan, diharapkan muncul sisi angka sebanyak50 kali 
dan muncul sisi gambar sebanyak 50 kali. Ternyata hasil pelemparan menunjukkan sisi gambar muncul sebanyak 15 kali dan sisi angka muncul sebanyak 85 kali. Pada tingkat signifikansi 5\%, berikut akan diuji apakah terjadi keselarasan, yakni dalam 100 kali lemparan menghasilkan angka dan gambar dalam proporsi yang sama (dengan kata lain, koin tidak berat sebelah).

\section{Tahap Pertama}

Tahap pertama adalah perumusah hipotesis. Berikut perumusan hipotesis.

$H_{0}$ : Proporsi/frekuensi kemunculan sisi angka dan gambar untuk pengamatan sama dengan proporsi/frekuensi kemunculan sisi angka dan gambar secara teoritis.

$H_{1}$ : Proporsi/frekuensi kemunculan sisi angka dan gambar untuk pengamatan berbeda dengan proporsi/frekuensi kemunculan sisi angka dan gambar secara teoritis.

\section{Tahap Kedua}

Tahap kedua adalah menghitung nilai kritis chi-kuadrat $\left(\chi_{\text {kritis }}^{2}\right)$ berdasarkan tabel distribusi chi-kuadrat. Sebelum menghitung nilai kritis chi-kuadrat, terlebih dahulu menghitung nilai derajat bebas. Berikut rumus untuk menghitung nilai derajat bebas.

$$
\text { Derajat bebas }=k-1 \text {. }
$$

Perhatikan bahwa $k$ merupakan jumlah kategori, yakni angka dan gambar, sehingga derajat bebas bernilai $2-1=1$. Nilai kritis 
chi-kuadrat dengan derajat bebas 1 dan tingkat signifikansi 5\% adalah 3,841. Nilai kritis chi-kuadrat juga dapat ditentukan dengan bantuan Microsoft Excel sebagai berikut.

\begin{tabular}{c|c|c|c|}
\hline \multicolumn{1}{c}{ Font } & $f_{x}$ & $=\mathrm{CHIINV}(\mathrm{B} 3, \mathrm{C} 3)$ & \\
\hline \hline B & $\mathrm{C}$ & $\mathrm{D}$ \\
\hline & & \\
\hline Tingkat Signifikansi & Derajat Bebas & Nilai Kritis Chi-Kuadrat \\
\hline 0.05 & 1 & 3.841459149 \\
\hline
\end{tabular}

\section{Gambar 9.1}

\section{Tahap Ketiga}

Tahap ketiga adalah menghitung nilai statistik dari uji chi$\operatorname{kuadrat}\left(\chi_{\text {hitung }}^{2}\right)$.

$\Rightarrow$ Sajikan informasi frekuensi harapan dan frekuensi pengamatan dalam tabel seperti berikut.

\section{Tabel 9.1}

\begin{tabular}{|c|c|c}
\hline Sisi Koin & Angka & Gambar \\
\hline Frekuensi Harapan (teoritis) & 50 & 50 \\
\hline Frekuensi Pengamatan & 85 & 15
\end{tabular}

Secara teoritis, probabilitas untuk muncul sisi angka dan sisi gambar pada koin adalah $\frac{1}{2}$, sehingga frekuensi harapan dalam pelemparan sekeping koin sebanyak 100 kali untuk masing-masing sisi adalah 


$$
\begin{aligned}
& \text { frekuensi harapan angka }=\frac{1}{2} \times(100 \text { kali lemparan }) \\
& =50 \text { kali muncul angka, } \\
& \text { frekuensi harapan gambar }=\frac{1}{2} \times(100 \text { kali lemparan }) \\
& =50 \text { kali muncul gambar. }
\end{aligned}
$$

Jadi, diharapkan dalam 100 kali lemparan sebuah koin, akan muncul sisi angka sebanyak 50 kali dan muncul sisi gambar sebanyak 50 kali.

$\Rightarrow$ Menghitung nilai statistik dari uji chi-kuadrat.

\section{Tabel 9.2}

\begin{tabular}{|c|c|c|c|c|}
\hline Kejadian & $E_{1}$ & $E_{2}$ & $\cdots$ & $E_{k}$ \\
\hline Frekuensi Harapan & $f_{H_{1}}$ & $f_{H_{2}}$ & $\cdots$ & $f_{H_{k}}$ \\
\hline Frekuensi Pengamatan & $f_{p_{1}}$ & $f_{P_{2}}$ & $\cdots$ & $f_{P_{k}}$
\end{tabular}

Berdasarkan Tabel 9.2, $E_{1}, E_{2}, \ldots, E_{k}$ merupakan kejadiankejadian yang mungkin terjadi dari suatu percobaan, $f_{H_{1}}, f_{H_{2}}, \ldots, f_{H_{k}}$ berturut-turut merupakan frekuensi harapan (expected) dari $E_{1}, E_{2}, \ldots, E_{k}$, dan $f_{p_{1}}, f_{P_{2}}, \ldots, f_{P_{k}}$ berturut-turut merupakan frekuensi pengamatan (observed) dari $E_{1}, E_{2}, \ldots, E_{k}$.

Dalam percobaan pelemparan sekeping koin sebanyak satu kali, kejadian-kejadian yang mungkin terjadi adalah muncul sisi angka atau muncul sisi gambar, sehingga

$$
E_{1}=\text { kejadian muncul angka }
$$




$$
E_{2}=\text { kejadian muncul gambar } \text {. }
$$

Berikut rumus untuk menghitung nilai statistik dari uji chi$\operatorname{kuadrat}\left(\chi_{\text {hitung }}^{2}\right)$.

$$
\begin{gathered}
\chi_{\text {hitung }}^{2}=\frac{\left(f_{P_{1}}-f_{H_{1}}\right)^{2}}{f_{H_{1}}}+\frac{\left(f_{P_{2}}-f_{H_{2}}\right)^{2}}{f_{H_{2}}}+\cdots+\frac{\left(f_{P_{k}}-f_{H_{k}}\right)^{2}}{f_{H_{k}}} \\
=\frac{(85-50)^{2}}{50}+\frac{(15-50)^{2}}{50} \\
=24,5+24,5 \\
=49 .
\end{gathered}
$$

\section{Tahap Keempat}

Tahap keempat adalah pengambilan keputusan terhadap hipotesis. Berikut aturan dalam pengambilan keputusan terhadap hipotesis.

$$
\begin{aligned}
& \text { Jika } \chi_{\text {hitung }}^{2} \leq \chi_{\text {kritis }}^{2}, H_{0} \text { diterima dan } H_{1} \text { ditolak. } \\
& \text { Jika } \chi_{\text {hitung }}^{2}>\chi_{\text {kritis }}^{2}, H_{0} \text { ditolak dan } H_{1} \text { diterima } .
\end{aligned}
$$

Diketahui nilai statistik dari uji chi-kuadrat adalah 49, dan nilai kritis chi-kuadrat adalah 3,841. Karena nilai statistik dari uji chikuadrat lebih besar dibandingkan nilai kritis chi-kuadrat, maka hipotesis nol ditolak dan hipotesis alternatif diterima. Hal ini berarti proporsi/frekuensi kemunculan sisi angka dan gambar untuk pengamatan berbeda dengan proporsi/frekuensi kemunculan sisi angka dan gambar secara teoritis pada tingkat signifikansi 5\%.

\section{Contoh Soal 2}


Misalkan sebuah mesin pencampur adonan kue menghasilkan perbandingan tepung, susu, telur, dan gula secara berturut-turut adalah 5:2:2:1. Seorang pembuat kue mengambil adonan yang dihasilkan oleh mesin tersebut $500 \mathrm{~kg}$, ternyata dalam adonan kue tersebut mengandung $275 \mathrm{~kg}$ tepung, $95 \mathrm{~kg}$ susu, $70 \mathrm{~kg}$ telur, dan $60 \mathrm{~kg}$ gula. Pada tingkat signifikansi 1\%, ujilah hipotesis apakah proporsi adonan kue yang telah dihasilkan sesuai dengan proporsi adonan yang telah ditetapkan pada mesin pencampur kue.

\section{Tahap Pertama}

Tahap pertama adalah perumusan hipotesis. Berikut perumusan hipotesis.

$H_{0}$ : Proporsi adonan kue yang telah dihasilkan sama dengan proporsi adonan kue yang telah ditetapkan pada mesin pencampur adonan kue.

$H_{1}$ : Proporsi adonan kue yang telah dihasilkan tidak sama dengan proporsi adonan kue yang telah ditetapkan pada mesin pencampur adonan kue.

\section{Tahap Kedua}

Tahap kedua adalah menentukan nilai kritis chi-kuadrat berdasarkan tabel distribusi chi-kuadrat. Diketahui nilai tingkat signifikansi adalah 1\%. Untuk menentukan nilai kritis chikuadrat, terlebih dahulu menentukan nilai derajat bebas. Berikut rumus dari derajat bebas. 


$$
\text { Derajat bebas }=k-1 \text {. }
$$

Perhatikan bahwa $k$ merupakan jumlah kategori. Diketahui jumlah kategori sebanyak 4, yakni tepung, susu, telur, dan gula, sehingga derajat bebas adalah $4-1=3$. Nilai kritis chi-kuadrat dengan derajat bebas 3 dan tingkat signifikansi 1\% adalah 11,345. Nilai kritis chi-kuadrat juga dapat ditentukan dengan Microsoft Excel sebagai berikut.

\begin{tabular}{c|c|c|c}
\hline \hline \multicolumn{1}{c|}{$f_{x}$} & $=\mathrm{CHIINV}(\mathrm{B} 3, \mathrm{C} 3)$ & \\
\hline \hline $\mathrm{B}$ & $\mathrm{C}$ & $\mathrm{D}$ & $\mathrm{E}$ \\
\hline & & \\
\hline Tingkat Signifikansi & Derajat Bebas & Nilai Kritis Chi-Kuadrat \\
\hline 0.01 & 3 & 11.34486668 \\
\hline
\end{tabular}

\section{Gambar 9.2}

\section{Tahap Ketiga}

Tahap ketiga adalah menghitung nilai statistik dari uji chi-kuadrat $\left(\chi_{\text {hitung }}^{2}\right)$.

$\Rightarrow$ Sajikan informasi antara proporsi adonan harapan dan proporsi adonan yang dihasilkan mesin dalam tabel berikut.

\section{Tabel 9.3}

\begin{tabular}{|c|c|c|c|c|}
\hline Adonan & Tepung & Susu & Telur & Gula \\
\hline Adonan Harapan & $250 \mathrm{~kg}$ & $100 \mathrm{~kg}$ & $100 \mathrm{~kg}$ & $50 \mathrm{~kg}$ \\
\hline Adonan yang Dihasilkan & $275 \mathrm{~kg}$ & $95 \mathrm{~kg}$ & $70 \mathrm{~kg}$ & $60 \mathrm{~kg}$ \\
\hline
\end{tabular}


Diharapkan dalam $500 \mathrm{~kg}$ adonan, kue tersebut mengandung:

$$
\begin{aligned}
& \frac{5}{10} \times 500 \mathrm{~kg}=250 \mathrm{~kg} \text { tepung } \\
& \frac{2}{10} \times 500 \mathrm{~kg}=100 \mathrm{~kg} \mathrm{susu} \\
& \frac{2}{10} \times 500 \mathrm{~kg}=100 \mathrm{~kg} \text { telur } \\
& \frac{1}{10} \times 500 \mathrm{~kg}=50 \mathrm{~kg} \text { gula } .
\end{aligned}
$$

$\Rightarrow$ Menghitung nilai statistik dari uji chi-kuadrat.

$$
\begin{gathered}
\chi_{\text {hitung }}^{2}=\frac{\left(f_{P_{1}}-f_{H_{1}}\right)^{2}}{f_{H_{1}}}+\frac{\left(f_{P_{2}}-f_{H_{2}}\right)^{2}}{f_{H_{2}}}+\cdots+\frac{\left(f_{P_{k}}-f_{H_{k}}\right)^{2}}{f_{H_{k}}} \\
=\frac{(275-250)^{2}}{250}+\frac{(95-100)^{2}}{100}+\frac{(70-100)^{2}}{100}+\frac{(60-50)^{2}}{50} \\
=2,5+0,25+9+2 \\
=13,75 .
\end{gathered}
$$

\section{Tahap Keempat}

Tahap keempat adalah pengambilan keputusan terhadap hipotesis. Berikut aturan pengambilan keputusan terhadap hipotesis.

Jika $\chi_{\text {hitung }}^{2} \leq \chi_{\text {kritis }}^{2}, H_{0}$ diterima dan $H_{1}$ ditolak. Jika $\chi_{\text {hitung }}^{2}>\chi_{\text {kritis }}^{2}, H_{0}$ ditolak dan $H_{1}$ diterima.

Diketahui nilai statistik dari uji chi-kuadrat adalah 13,75, dan nilai kritis chi-kuadrat adalah 11,345. Karena nilai statistik dari uji chikuadrat lebih besar dibandingkan nilai kritis chi-kuadrat, maka 
hipotesis nol ditolak dan hipotesis alternatif diterima. Hal ini berarti proporsi adonan kue yang telah dihasilkan tidak sama dengan proporsi adonan kue yang telah ditetapkan pada mesin pencampur adonan kue pada tingkat signifikansi $1 \%$.

\section{PENYELESAIAN DENGAN SPSS, MINITAB, DAN R}

\section{PENYELESAIAN DALAM SPSS (UJI TANDA)}

Bangun data dalam SPSS seperti pada Gambar 10.1. Pada Variable View, bentuk variabel Sebelum dan Sesudah. Kemudian atur tipe data (Type) dengan Numeric. Pada Data View, isi data berat badan sebelum mengkonsumsi obat penambah berat badan merek $X Y Z$, dan data berat badan sesudah mengkonsumsi obat penambah berat badan merek $X Y Z$ selama satu minggu. Kemudian pilih Analyze $=>$ Nonparametric Tests $=>2$ Related Samples (Gambar 10.2). Pindahkan variabel Sebelum pada bagian Variable1, sedangkan variabel Sesudah dipindahkan pada bagian 
Variable2 (Gambar 10.3). Pada bagian Test Type pilih Sign (Gambar 10.3). Kemudian pilih OK.

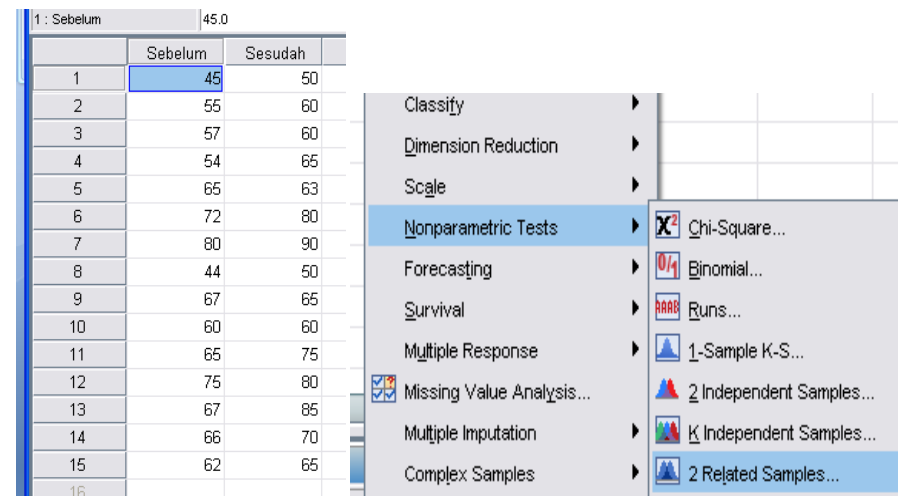

Gambar 10.1Gambar 10.2

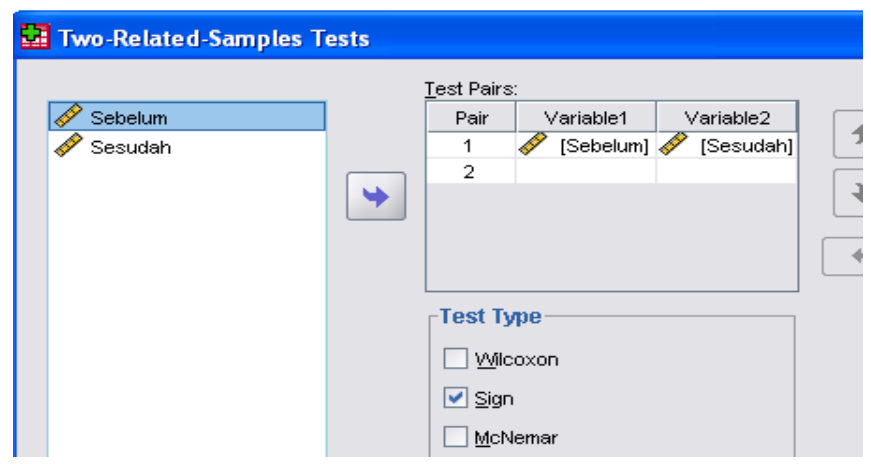

Gambar 10.3

Tabel 10.1, yakni Tabel Frequencies merupakan hasil berdasarkan SPSS. Berdasarkan Tabel 10.1, diketahui selisih dari pasangan nilai data yang bernilai negatif (Negative Differences) sebanyak 2, selisih dari pasangan nilai data yang bernilai positif (Positive Differences) sebanyak 12, dan selisih dari pasangan nilai data yang bernilai nol (Ties) sebanyak 1. Jumlah responden dalam sampel (Total) sebanyak 15. 


\section{Tabel 10.1}

\section{Frequencies}

\begin{tabular}{|ll|r|}
\hline & $\mathrm{N}$ \\
\hline Sesudah - Sebelum & Negative Differences $^{\mathrm{a}}$ & 2 \\
& Positive Differences $^{\mathrm{b}}$ & 12 \\
& Ties $^{\mathrm{c}}$ & 1 \\
& Total & 15 \\
\hline
\end{tabular}

a. Sesudah $<$ Sebelum

b. Sesudah > Sebelum

c. Sesudah $=$ Sebelum

Tabel 10.2

Test Statistics ${ }^{\mathrm{b}}$

\begin{tabular}{|l|c|}
\hline & $\begin{array}{c}\text { Sesudah - } \\
\text { Sebelum }\end{array}$ \\
\hline Exact Sig. (2-tailed) & $.013^{\mathrm{a}}$ \\
\hline
\end{tabular}

a. Binomial distribution used.

b. Sign Test

Tabel 10.2, yakni Tabel Test Statistics merupakan hasil berdasarkan SPSS. Berdasarkan Tabel 10.2, diketahui nilai Exact Sig. (2-tailed) adalah 0,013, yang mana merupakan nilai probabilitas kumulatif dari $X=2$. Perhatikan bahwa karena nilai Exact Sig. (2-tailed) atau probabilitas kumulatif untuk $X=2$, yakni 0,013, lebih kecil dari nilai tingkat signifikansi, yakni 0,05, maka hipotesis nol ditolak dan hipotesis alternatif diterima. Ini berarti pernyataan "terdapat perbedaan yang signifikan (secara statistika) mengenai berat badan sebelum dan sesudah 
mengkonsumsi obat penambah berat badan merek XYZ" dapat diterima pada tingkat signifikansi 5\%.

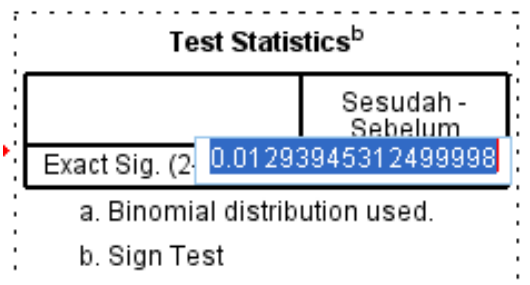

\section{Gambar 10.4}

Pada Gambar 10.4 menyajikan nilai nilai probabilitas kumulatif dari $X=2$ yang lebih detail (17 angka di belakang koma).

\section{PENYELESAIAN DALAM Minitab (UJI TANDA)}

Bangun data dalam Minitab seperti pada Gambar 10.5. Pilih Cal

=>Calculator (Gambar 10.6).

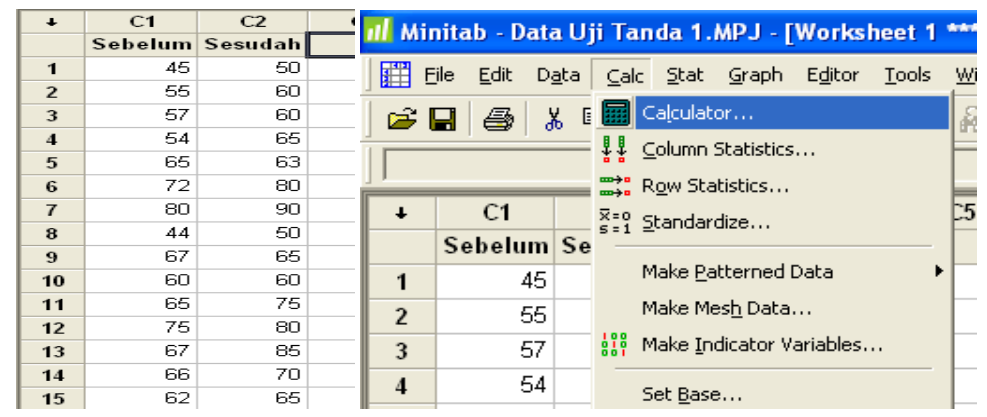

\section{Gambar 10.5}

Gambar 10.6 


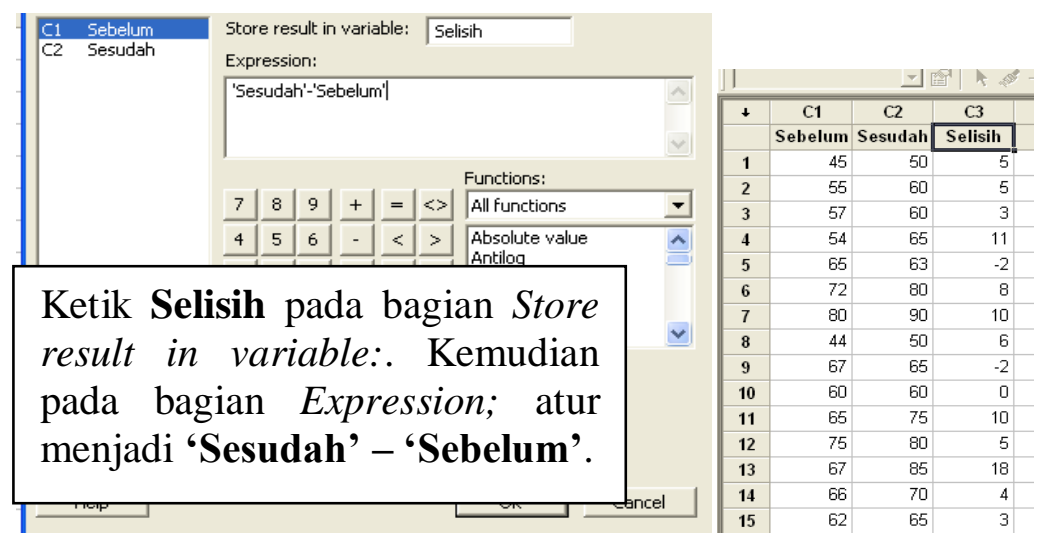

\section{Gambar 10.7}

\section{Gambar 10.8}

Pada Gambar 10.7, ketik Selisih pada bagian Store result in variable: Kemudian pada bagian Expression; atur menjadi 'Sesudah' - 'Sebelum'. Selanjutnya pilih OK, hasilnya seperti pada Gambar 10.8, di mana telah terbentuk varaibel Selisih.

Selanjutnya pilih Stat $=>$ Nonparametrics $=>1$-sample Sign (Gambar 10.9). Pada Gambar 10.10, masukkan variabel Selisih pada bagian Variables:. Kemudian aktifkan/bulatkan bagian Test median dan pada Alternative: pilih not equal dengan maksud untuk pengujian dua arah. Kemudian pilih $\mathrm{OK}$. 


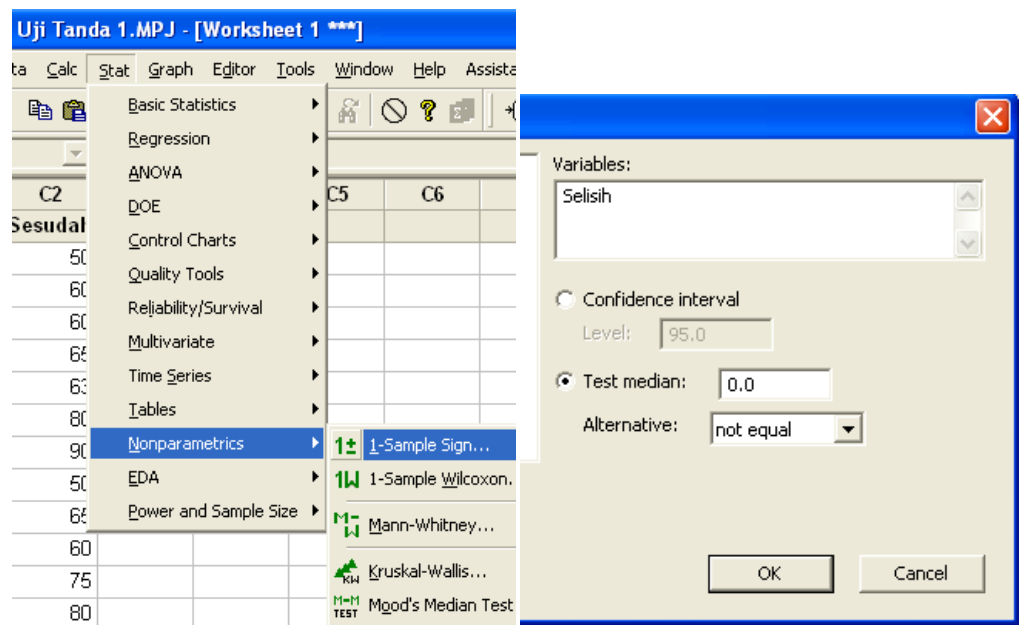

Gambar 10.9

Gambar 10.10

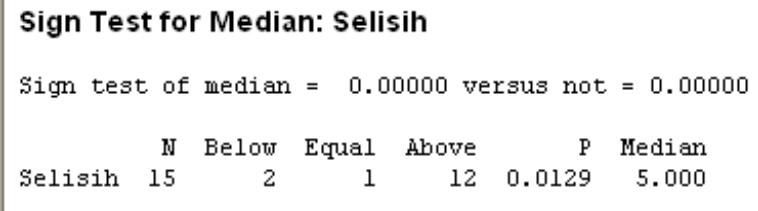

\section{Gambar 10.11}

Berdasarkan Gambar 10.11, diketahui nilai $P$ adalah 0,0129, di mana nilai tersebut merupakan nilai probabilitas kumulatif dari $X=2$. Perhatikan bahwa karena nilaiprobabilitas kumulatif untuk $X=2$, yakni 0,0129 , lebih kecil dari nilai tingkat signifikansi, yakni 0,05, maka hipotesis nol ditolak dan hipotesis alternatif diterima. Ini berarti pernyataan "terdapat perbedaanyang signifikan (secara statistika) mengenai berat badan sebelum dan sesudah mengkonsumsi obat penambah berat badan merek XYZ" dapat diterima pada tingkat signifikansi 5\%.

\section{PENYELESAIAN DALAM R (UJI TANDA)}


Aktifkan RStudio terlebih dahulu. Kemudian pilih New File $=>R$ Script (Gambar 10.12). Pada Gambar 10.13, ketik perintah binom.test( $2,14,0.5$, alternative="two.sided").

\section{binom.test $(2,14,0.5$, alternative="two.sided").}

$\Rightarrow$ Nilai 2 berarti jumlah tanda paling sedikit, yakni jumlah tanda negatif.

$\Rightarrow$ Nilai 14 berarti jumlah seluruh tanda, yakni tanda positif dan tanda negatif.

$\Rightarrow$ Two.sided berarti pengujian dua arah.

$\Rightarrow$ Perhitungan nilai probabilitas kumulatif $X=2$ dihitung dengan rumus binomial.

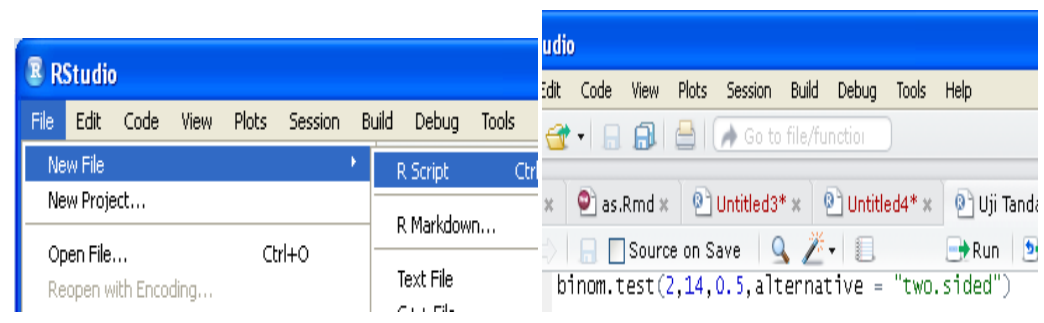

Gambar 10.12

Gambar 10.13

Gambar 10.14 merupakan hasil berdasarkan R. Diketahui nilai probabilitas kumulatif dari $X=2$ atau $p$-value $=0,01294$. Perhatikan bahwa karena nilaiprobabilitas kumulatif untuk $X=2$, yakni 0,01294, lebih kecil dari nilai tingkat signifikansi, yakni 0,05, maka hipotesis nol ditolak dan hipotesis alternatif diterima. Ini berarti pernyataan "terdapat perbedaan yang signifikan (secara statistik) mengenai berat badan sebelum dan sesudah 
mengkonsumsi obat penambah berat badan merek XYZ" dapat diterima pada tingkat signifikansi 5\%.

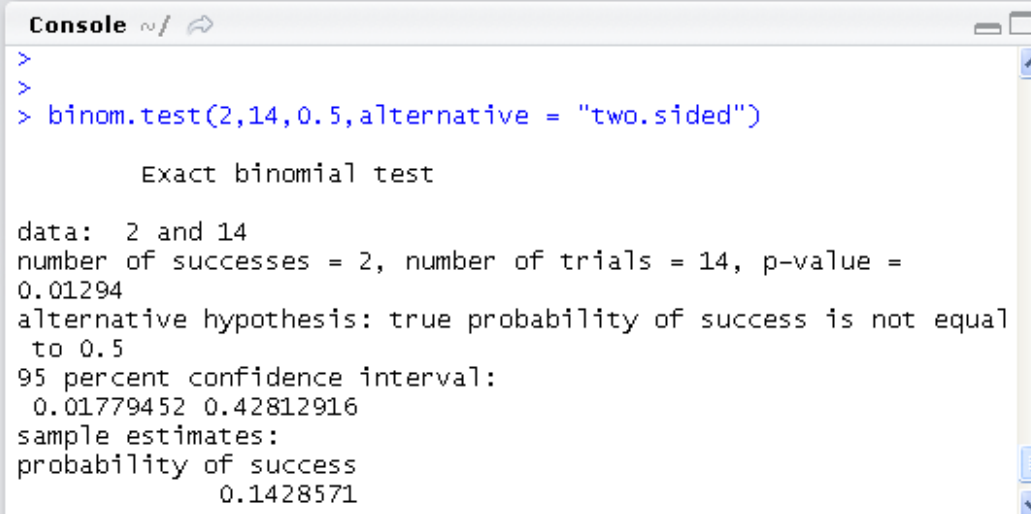

Gambar 10.14

\section{PENYELESAIAN DALAM SPSS (UJI WILCOXON)}

Bangun data dalam SPSS seperti pada Gambar 10.15. Pada Variable View, bentuk variabel Sebelum dan Sesudah. Kemudian atur tipe data (Type) dengan Numeric. Pada Data View, isi data 
berat badan sebelum mengkonsumsi obat penambah berat badan merek $X Y Z$, dan data berat badan sesudah mengkonsumsi obat penambah berat badan merek $X Y Z$ selama satu minggu.

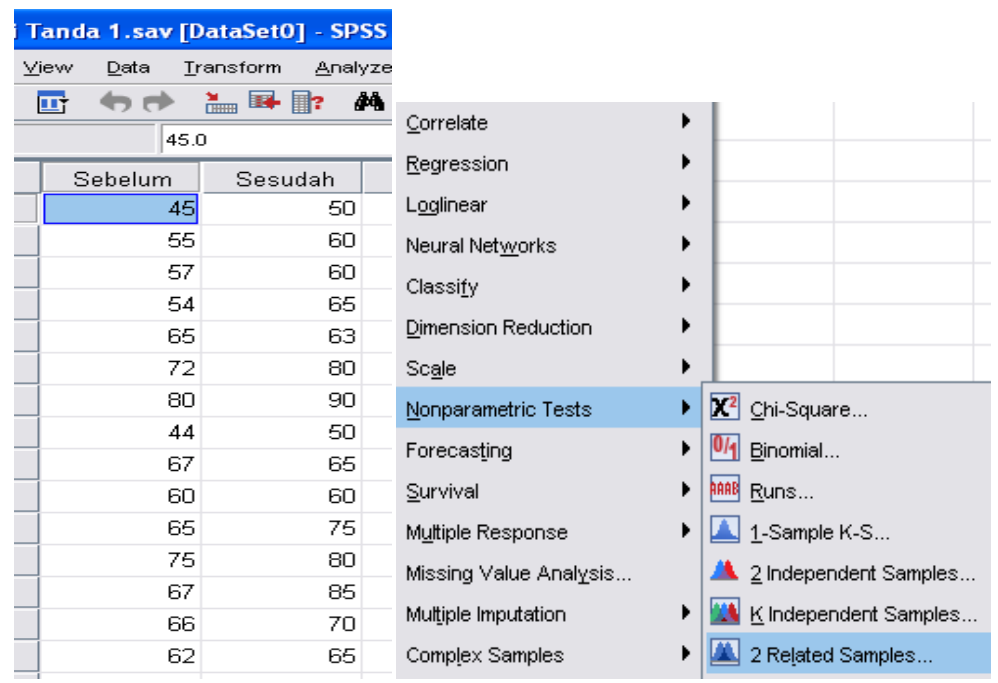

\section{Gambar 10.15 Gambar 10.16}

Kemudian pilih Analyze $=>$ Nonparametric Tests $=>2$ Related Samples (Gambar 10.16). Pindahkan variabel Sebelum pada bagian Variable1, sedangkan variabel Sesudah dipindahkan pada bagian Variable2 (Gambar 10.17). Pada bagian Test Type pilih Wilcoxon (Gambar 10.17). Kemudian pilih OK. 


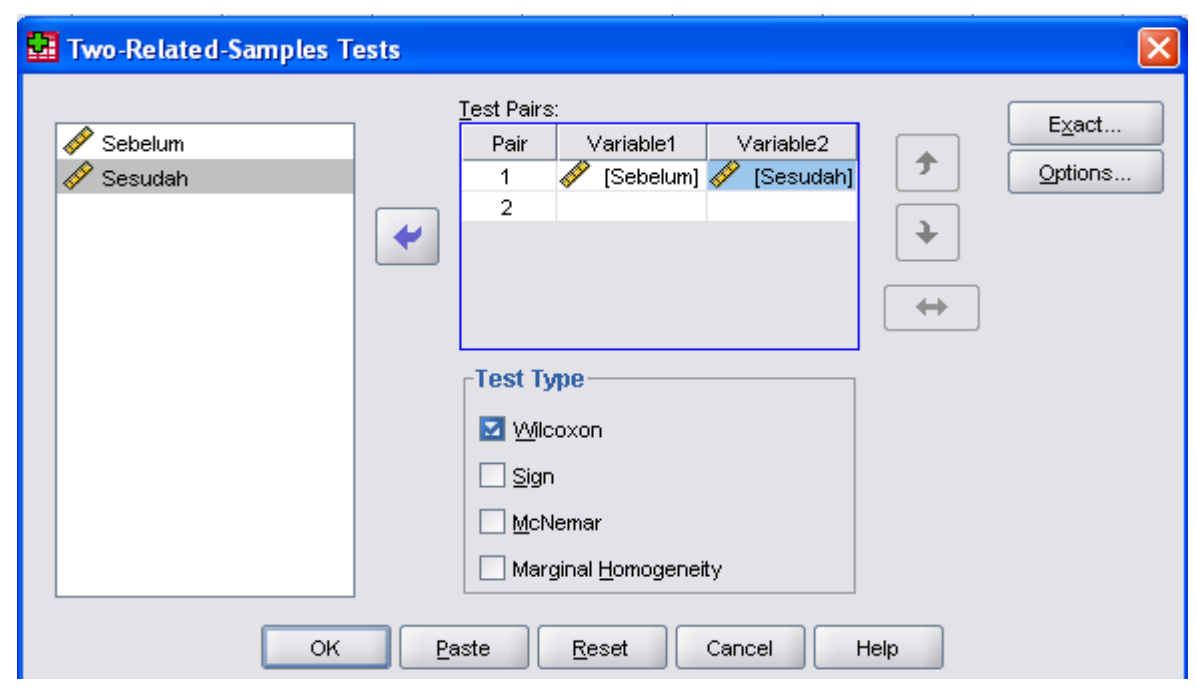

Gambar 10.17

Tabel 10.3, yakni Tabel Ranks merupakan hasil berdasarkan SPSS. Berdasarkan Tabel 10.3, diketahui selisih dari pasangan nilai data yang bernilai negatif atau pengamatan ranking yang negatif (Negative Ranks) sebanyak 2, selisih dari pasangan nilai data yang bernilai positif atau pengamatan ranking yang positif (Positive Ranks) sebanyak 12, dan selisih dari pasangan nilai data yang bernilai nol (Ties) sebanyak 1. Jumlah responden dalam sampel (Total) sebanyak 15. Diketahui jumlah ranking untuk kelompok tanda positif $(+)$ adalah 102, sedangkan jumlah ranking untuk kelompok tanda negatif (-) adalah 3. Hasil pada Tabel Ranks tersebut sesuai dengan hasil dengan perhitungan secara manual. 


\section{Tabel 10.3}

\begin{tabular}{|ll|r|r|r|}
\hline & & Ranks & Mean Rank & Sum of Ranks \\
\hline Sesudah - Sebelum & Negative Ranks & $2^{\mathrm{a}}$ & 1.50 & 3.00 \\
& Positive Ranks & $12^{\mathrm{b}}$ & 8.50 & 102.00 \\
& Ties & $1^{\mathrm{c}}$ & & \\
& Total & 15 & & \\
& & & \\
\hline
\end{tabular}

a. Sesudah $<$ Sebelum

b. Sesudah $>$ Sebelum

c. Sesudah $=$ Sebelum

Tabel 10.4

Test Statistics $^{\mathrm{b}}$

\begin{tabular}{|l|r|}
\hline & \multicolumn{1}{|c|}{$\begin{array}{c}\text { Sesudah - } \\
\text { Sebelum }\end{array}$} \\
\hline$Z$ & $-3.113^{\mathrm{a}}$ \\
Asymp. Sig. (2-tailed) & .002 \\
\hline
\end{tabular}

a. Based on negative ranks.

b. Wilcoxon Signed Ranks Test

Tabel 10.4, yakni Tabel Test Statistics merupakan hasil berdasarkan SPSS. Berdasarkan Tabel 10.4, diketahui nilai normal $Z$ terstandarisasi adalah $-3,113$, sedangkan nilai probabilitas kumulatif dari $Z$ (Asymp. Sig. (2-tailed)) adalah 0,002. Karena nilai probabilitas $0,002<\alpha=0,05$, maka hipotesis nol ditolak dan hipotesis alternatif diterima. Ini berarti pernyataan "terdapat perbedaan yang signifikan secara statistika mengenai berat badan, sebelum dan sesudah mengkonsumsi obat penambah berat badan merek XYZ" dapat diterima pada tingkat signifikansi 5\%. Perhatikan bahwa "(2-tailed)" berarti pengujian dilakukan secara dua arah. 


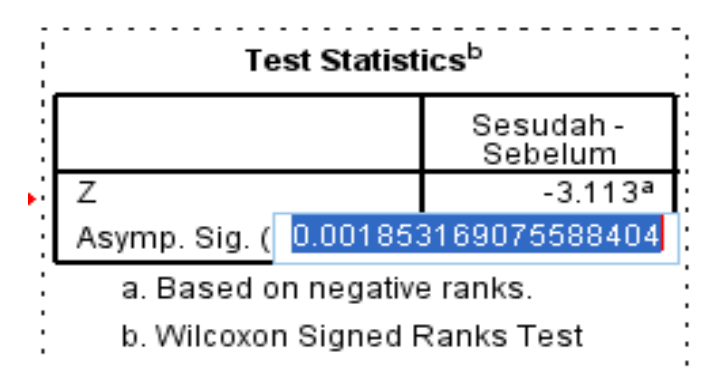

\section{Gambar 10.18}

Pada Gambar 10.18 menyajikan nilai nilai probabilitas kumulatif dari $Z$ yang lebih detail (18 angka di belakang koma).

\section{PENYELESAIAN DALAM Minitab (UJI WILCOXON)}

Bangun data dalam Minitab seperti pada Gambar 2.19. Pilih Cal =>Calculator (Gambar 10.20).

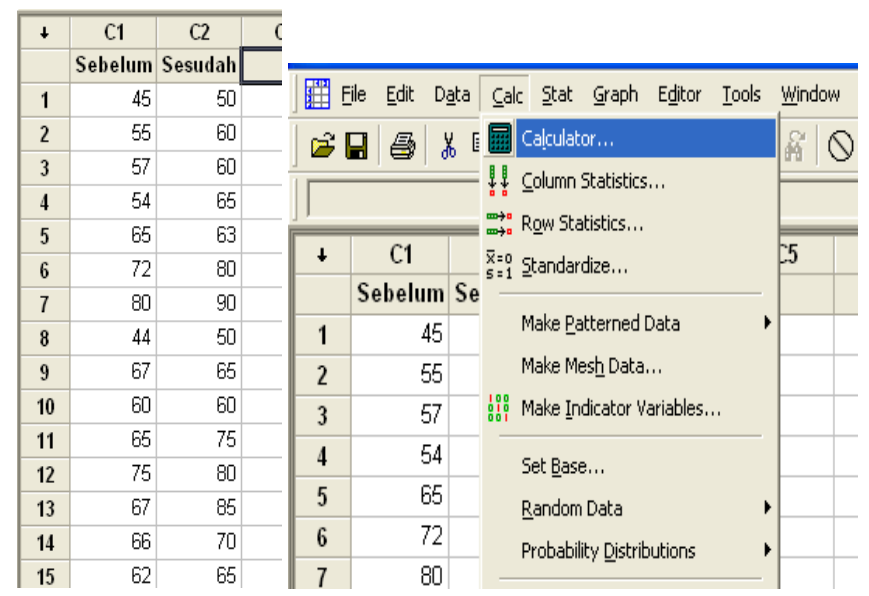

\section{Gambar 10.19Gambar 10.20}

Pada Gambar 10.21, ketik Selisih pada bagian Store result in variable: Kemudian pada bagian Expression; atur menjadi 
'Sesudah' - 'Sebelum'. Selanjutnya pilih OK, hasilnya seperti pada Gambar 10.22, di mana telah terbentuk varaibel Selisih.

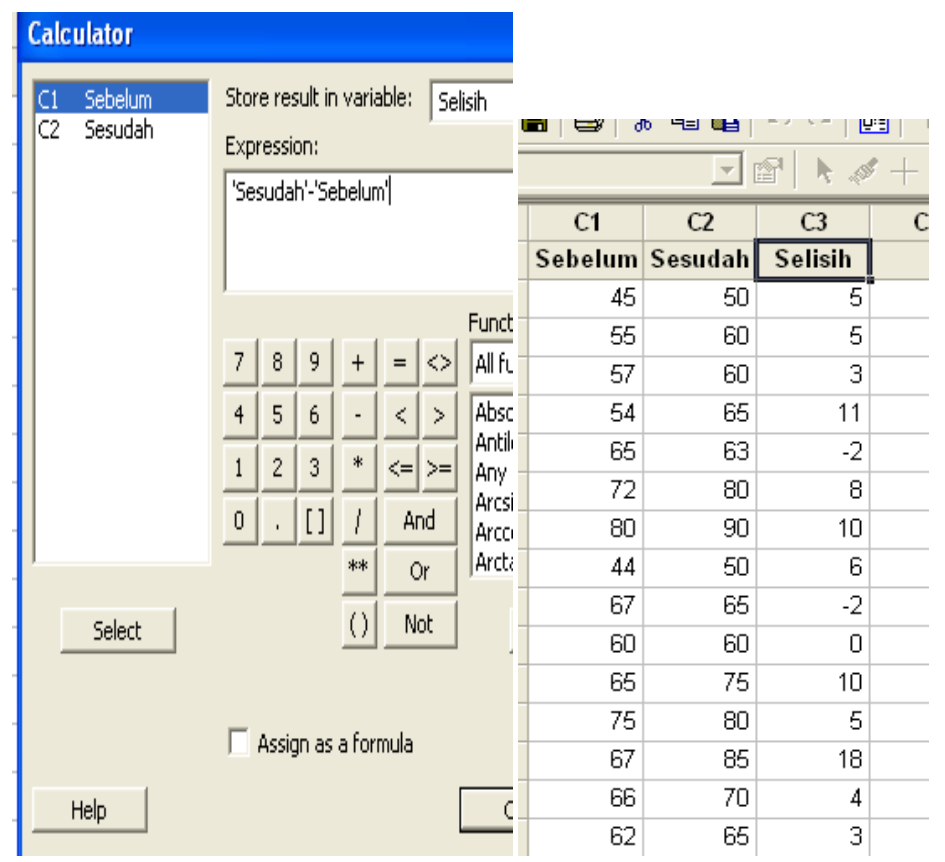

\section{Gambar 10.21 Gambar 10.22}

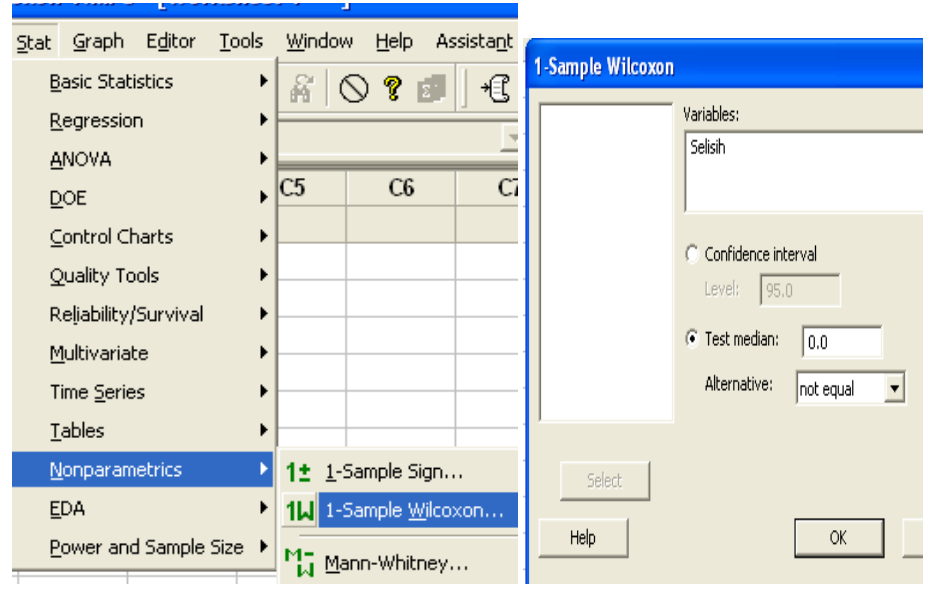

Gambar 10.23

Gambar 10.24 
Selanjutnya pilih Stat $=>$ Nonparametrics $=>1$-sample Wilcoxon (Gambar 10.23). Pada Gambar 2.24, masukkan variabel Selisih pada bagian Variables:. Kemudian aktifkan/bulatkan bagian Test median dan pada Alternative: pilih not equal dengan maksud untuk pengujian dua arah. Kemudian pilih OK.

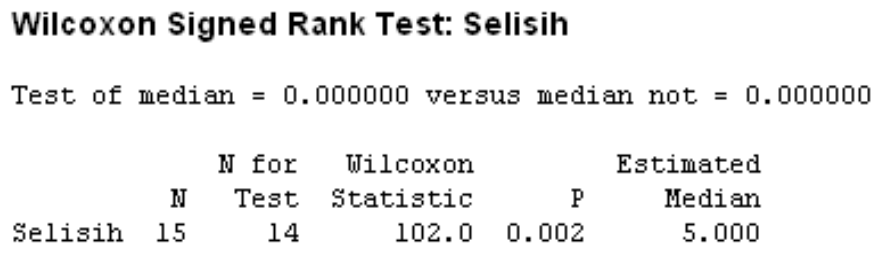

\section{Gambar 10.25}

Berdasarkan Gambar 10.25, diketahui nilai $P$ adalah 0,002 , di mana nilai tersebut merupakan nilai probabilitas kumulatif nilai normal $Z$ terstandarisasi, yakni $Z=-3,11$.Karena nilai probabilitas $0,002<\alpha=0,05$, maka hipotesis nol ditolak dan hipotesis alternatif diterima. Ini berarti pernyataan "terdapat perbedaan yang signifikan secara statistika mengenai berat badan, sebelum dan sesudah mengkonsumsi obat penambah berat badan merek XYZ" dapat diterima pada tingkat signifikansi 5\%. Perhatikan bahwa "(2-tailed)" berarti pengujian dilakukan secara dua arah. 


\section{PENYELESAIAN DALAM R (UJI WILCOXON)}

Data terlebih dahulu disimpan dalam Microsoft Excel dengan tipe .CSV (Comma Separeted Values) (Gambar 10.26 dan Gambar 10.27).

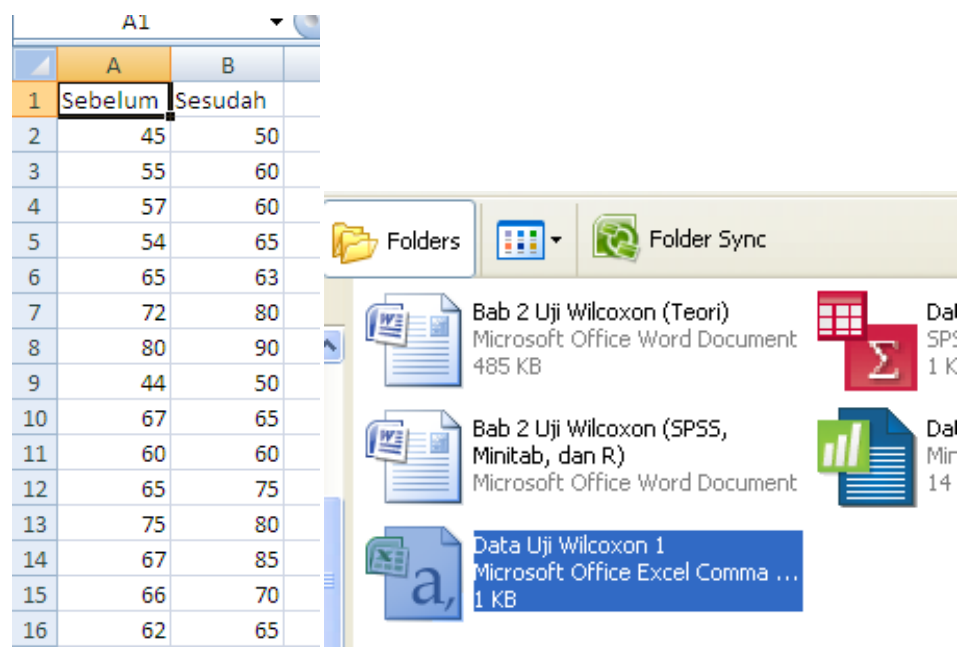

\section{Gambar 10.26 Gambar 10.27}

Aktifkan RStudio, kemudian pilih File $=>R$ Script . Ketik perintah R seperti pada Gambar 10.28.

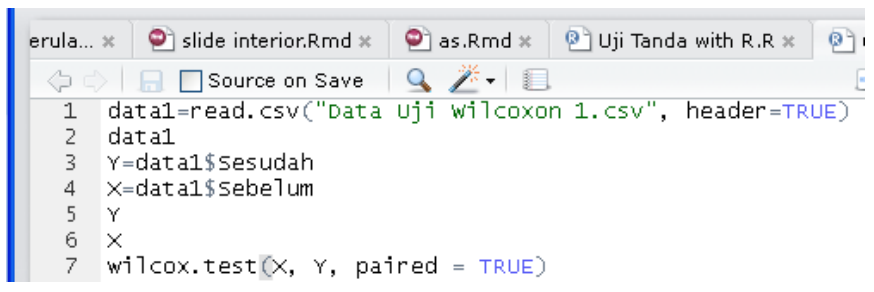

\section{Gambar 10.28}

Selanjutnya pilih Compile, pilih MS Word pada Notebook output format, dan Compile. Berikut hasil berdasarkan berdasarkan R. 


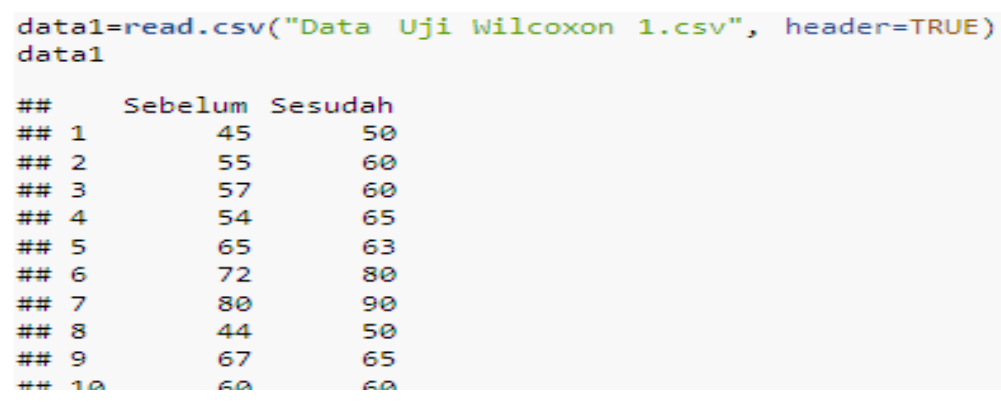

Gambar 10.29

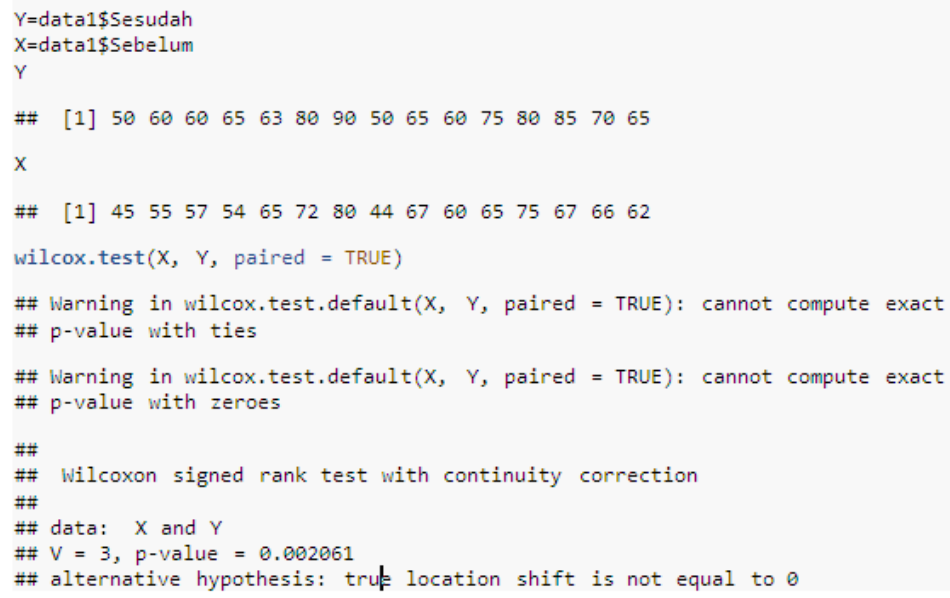

\section{Gambar 10.30}

Perhatikan bahwa berdasarkan Gambar 10.30 , nilai $\mathrm{V}=3$, di mana nilai tersebut merupakan nilai statistik dari uji Wilcoxon. Karena nilai statistik dari uji Wilcoxon, yakni 3 lebih kecil dari nilai kritis Wilcoxon, yakni 21, maka hipotesis nol ditolak dan hipotesis alternatif diterima. Ini berarti pernyataan mengenai "terdapat perbedaan yang signifikan (secara statistika) mengenai berat badan, sebelum mengkonsumsi obat penambah berat badan merek $X Y Z$ dan sesudah mengkonsumsi obat penambah berat badan 
merek $X Y Z$ selama satu minggu" dapat diterima pada tingkat signifikansi 5\%.

Berdasarkan Gambar 10.30 juga diketahui nilai $p$-value (setelah koreksi)adalah 0,002061.Karena nilai probabilitas 0,002061< $\alpha=0,05$, maka hipotesis nol ditolak dan hipotesis alternatif diterima. Ini berarti pernyataan "terdapat perbedaan yang signifikan secara statistika mengenai berat badan, sebelum dan sesudah mengkonsumsi obat penambah berat badan merek XYZ" dapat diterima pada tingkat signifikansi 5\%. Perhatikan bahwa "(2-tailed)" berarti pengujian dilakukan secara dua arah. Pada Gambar 10.31 menyajikan kode $\mathrm{R}$ untuk uji Wilcoxon tanpa koreksi.

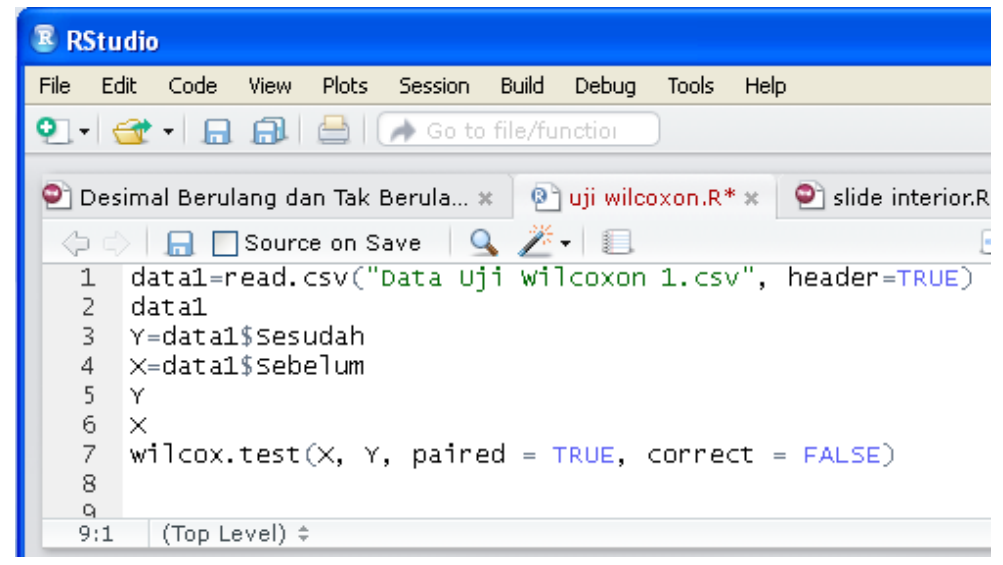

\section{Gambar 10.31}

Dengan melakukan compile kode R pada Gambar 10.31, diperoleh hasil seperti pada Gambar 10.32. Berdasarkan Gambar 10.32, diketahui nilai p-value (sebelum koreksi)adalah 0,001853, di mana nilai tersebut merupakan nilai probabilitas kumulatif 
nilainormal $Z$ terstandarisasi, yakni $Z=-3,11$.Karena nilai probabilitas $0,001853<\alpha=0,05$, maka hipotesis nol ditolak dan hipotesis alternatif diterima. Ini berarti pernyataan "terdapat perbedaan yang signifikan secara statistika mengenai berat badan, sebelum dan sesudah mengkonsumsi obat penambah berat badan merek XYZ" dapat diterima pada tingkat signifikansi $5 \%$. Perhatikan bahwa "(2-tailed)" berarti pengujian dilakukan secara dua arah.

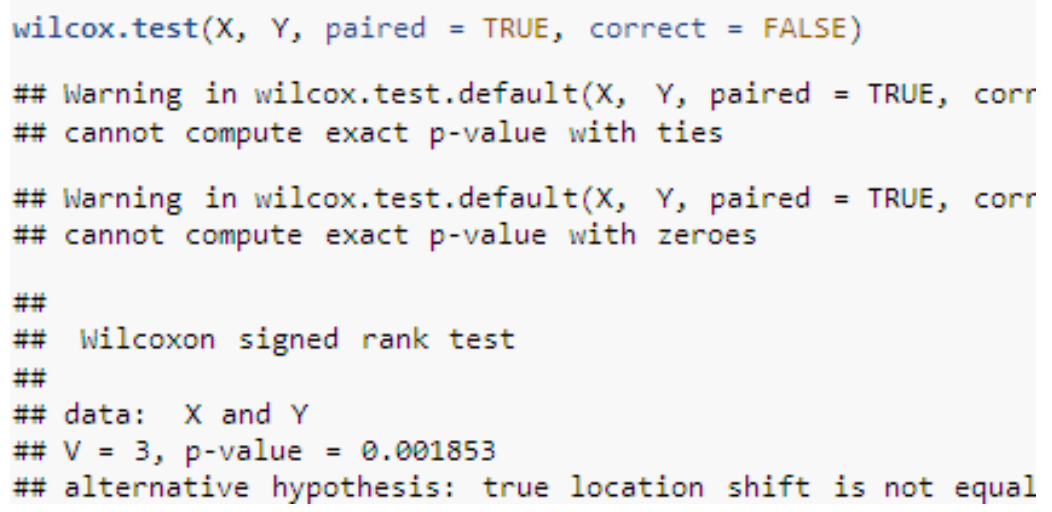

\section{Gambar 10.32}




\section{PENYELESAIAN DALAM SPSS (UJI MANN-WHITNEY)}

Bangun data dalam SPSS seperti pada Gambar 10.33. Pada Variable View, bentuk variabel Jurusan dan Nilai. Kemudian atur tipe data (Type) dengan Numeric. Untuk variabel Jurusan, beri Value 0 untuk Label "Matematika", dan Value 1 untuk Label "Statistika" (lihat Gambar 3.1). Kemudian aktifkan Data View. Ketik data seperti pada Gambar 10.33. Berdasarkan Gambar 10.33, diketahui masing-masing jurusan diamati 10 mahasiswa. Pada kolom Jurusan, nilai 0 menyatakan jurusan matematika, sedangkan nilai 1 menyatakan jurusan statistika.

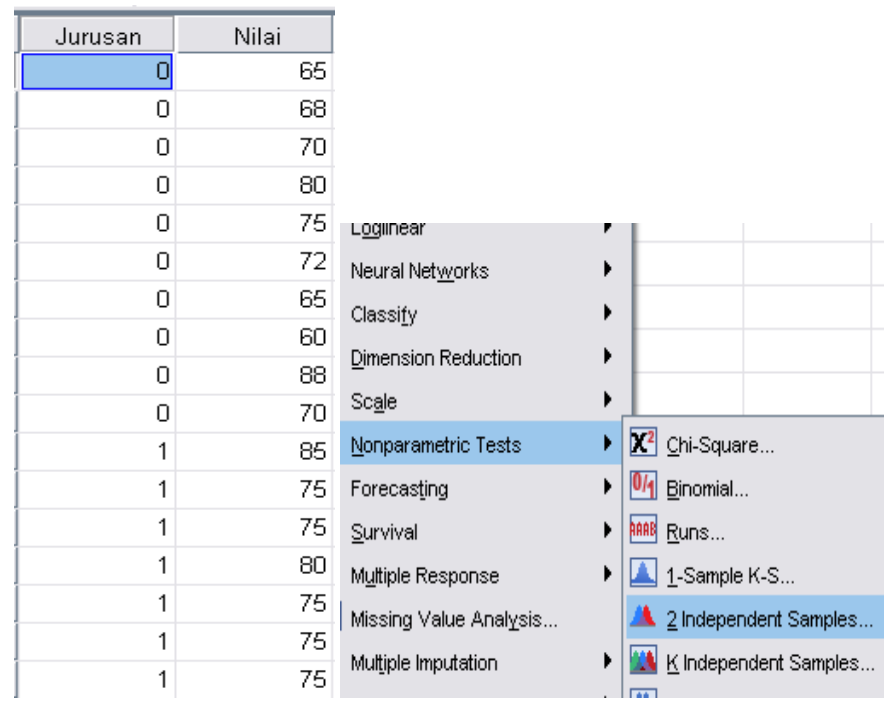

Gambar 10.33

Gambar 10.34

Pilih Analyze $\Rightarrow$ Nonparametric Tests $\Rightarrow 2$ Independent Samples(Gambar 10.34), sehingga muncul kotak dialog Two Independent Samples Test (Gambar 10.35). Pada Gambar 10.35, variabel Nilai dimasukkan pada kotak Test Variable List dan 
variabel Jurusan dimasukkan pada kotak Grouping Variable. Pada Test Type,pilih Mann-Whitney U. Selanjutnya pilih Define Groups, sehingga muncul kotak dialog Two Independent Samples: Define Groups. Pada kotak Two Independent Samples: Define Groups,ketik 0 pada Group 1,dan ketik 1 pada Group 2. Angka 0 berarti untuk kode jurusan matematika dan angka 1 untuk kode jurusan statistika. Kemudian pilih Continue dan $O K$.

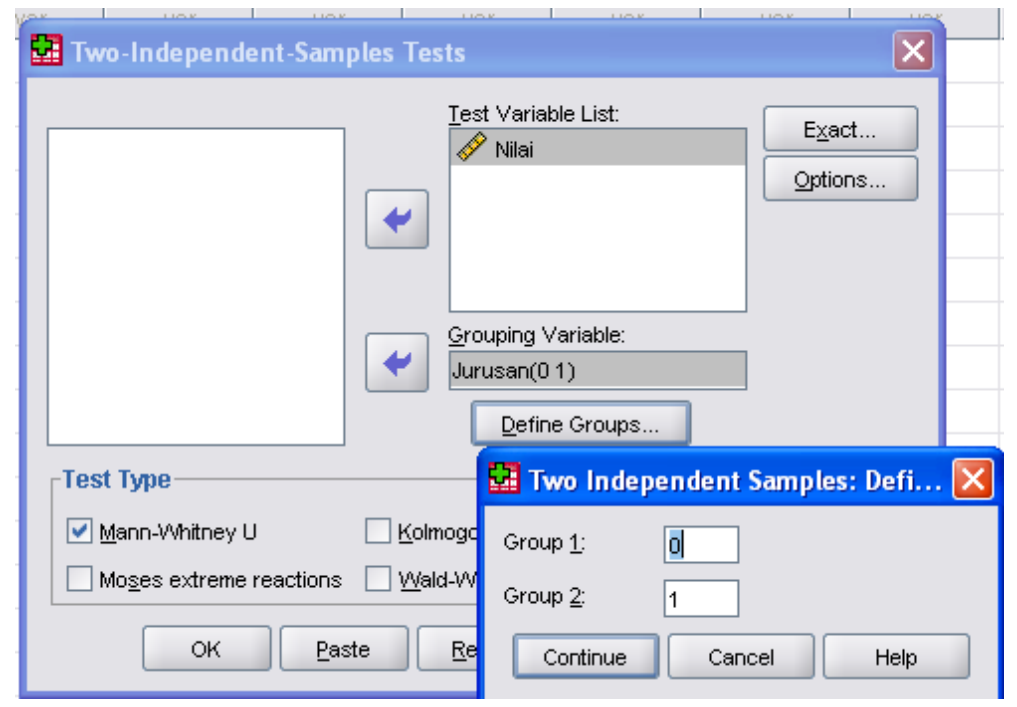

\section{Gambar 10.35}

Tabel 10.5, yakni Tabel Rank merupakan hasil berdasarkan SPSS. Padakolom Sum of Ranks, diketahui jumlah ranking nilai ujian matakuliah kalkulus mahasiswa jurusan matematika adalah 72,5 dan jumlah ranking nilai ujian matakuliah kalkulus mahasiswa jurusan statistika adalah 137,5. Pada kolom Mean Rankmerupakan nilai rata-rata dari ranking nilai ujian matakuliah kalkulus berdasarkan masing-masing jurusan. 


\section{Tabel 10.5}

\begin{tabular}{|ll|r|r|r|}
\hline \multicolumn{5}{|c|}{ Ranks } \\
\hline Nilai & Jurusan & N & Mean Rank & \multicolumn{1}{c|}{ Sum of Ranks } \\
& Statistika & 10 & 7.25 & 72.50 \\
& Total & 10 & 13.75 & 137.50 \\
& 20 & & \\
\hline
\end{tabular}

Pada Tabel 10.6 (Tabel Test Statistics) diketahui nilai statistik uji Mann-Whitney adalah 17,5. Nilai kritis Mann-Whitney adalah 23. Karena nilai dari statistik dari uji Mann-Whitney, yakni 17,5 lebih kecil dari nilai kritis Mann-Whitney, yakni 23, maka hipotesis nol ditolak dan hipotesis alternatif diterima. Ini berarti pernyataan mengenai "terdapat perbedaan yang signifikan secara statistika mengenai nilai ujian matakuliah kalkulus antara mahasiswa jurusan matematika dan mahasiswa jurusan statistika" dapat diterima pada tingkat signifikansi 5\%. Perhatikan juga bahwa diketahui nilai Asymp. Sig. (2-tailed)adalah 0,013. Nilai tersebut merupakan:

$2 \times($ nilai probabilitas kumulatif dari nilai normal $Z=-2,497)=$ $2 \times 0,0062=0,013$.

Karena nilai probabilitas kumulatif $0,013<\alpha=0,05$, maka hipotesis nol ditolak dan hipotesis alternatif diterima. Ini berarti pernyataan mengenai "nilai ujian matakuliah kalkulus mahasiswa jurusan statistika berbeda signifikan secara statistika dengan nilai ujian matakuliah kalkulus mahasiswa jurusan matematika" dapat diterima pada tingkat signifikansi 5\%. Perhatikan bahwa "(2tailed)" berarti pengujian dilakukan secara dua arah. 
Tabel 10.6

\begin{tabular}{|c|c|}
\hline \multicolumn{2}{|l|}{ Test Statistics $^{b}$} \\
\hline & Nilai \\
\hline Mann-Whitney U & 17.500 \\
\hline Wilcoxon W & 72.500 \\
\hline $\mathrm{z}$ & -2.497 \\
\hline Asymp. Sig. (2-tailed) & .013 \\
\hline Exact Sig. [2 $2^{2}(1$-tailed Sig. $\left.)\right]$ & $.011^{\circ}$ \\
\hline
\end{tabular}

a. Not corrected for ties.

b. Grouping Variable: Jurusan
Tabel 10.7

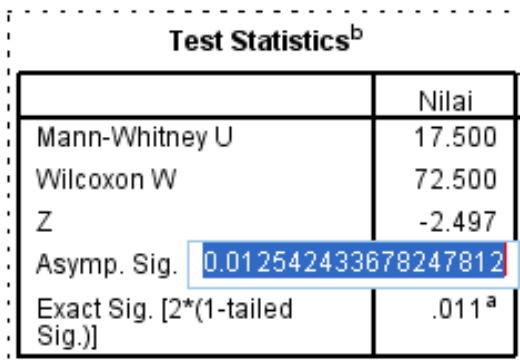

a. Not corrected for ties.

b. Grouping Variable: Jurusan

\section{PENYELESAIAN DALAM Minitab (UJI MANN- WHITNEY)}

Bangun data dalam Minitab seperti pada Gambar 10.36. Pilih Stat =>Nonparametrics $=>$ Mann-Whitney (Gambar 10.37).

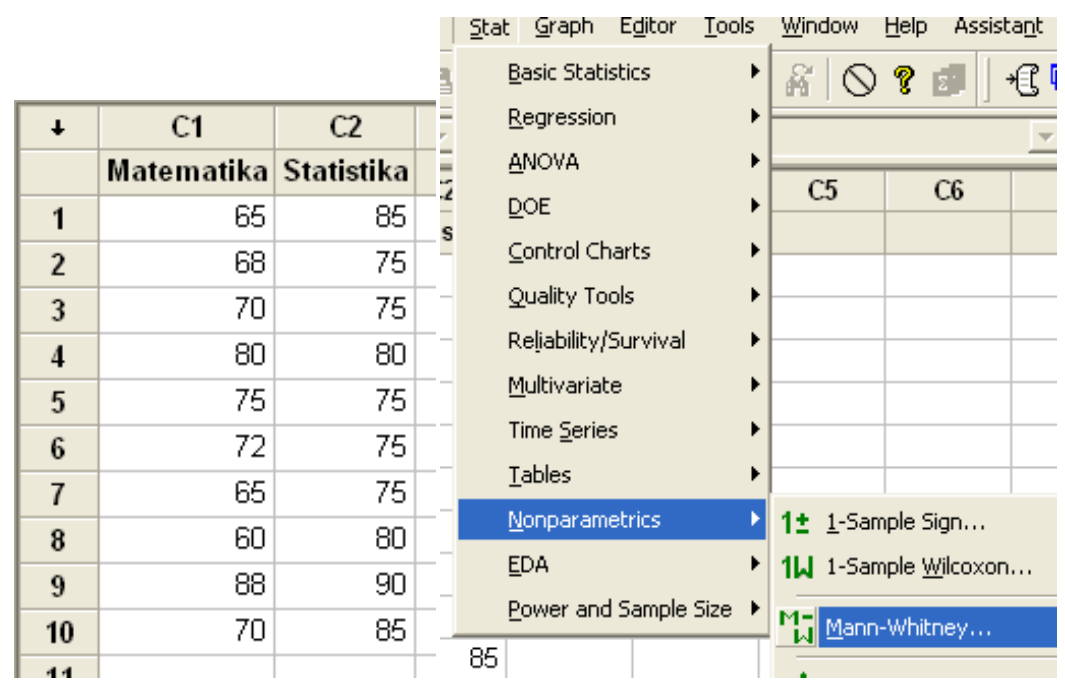

\section{Gambar 10.36 Gambar 10.37}


Pada Gambar 10.38, pindahkan variabel Matematika pada First Sample, dan pindahkan variabel Statistika pada Second Sample. Kemudian pilih OK.

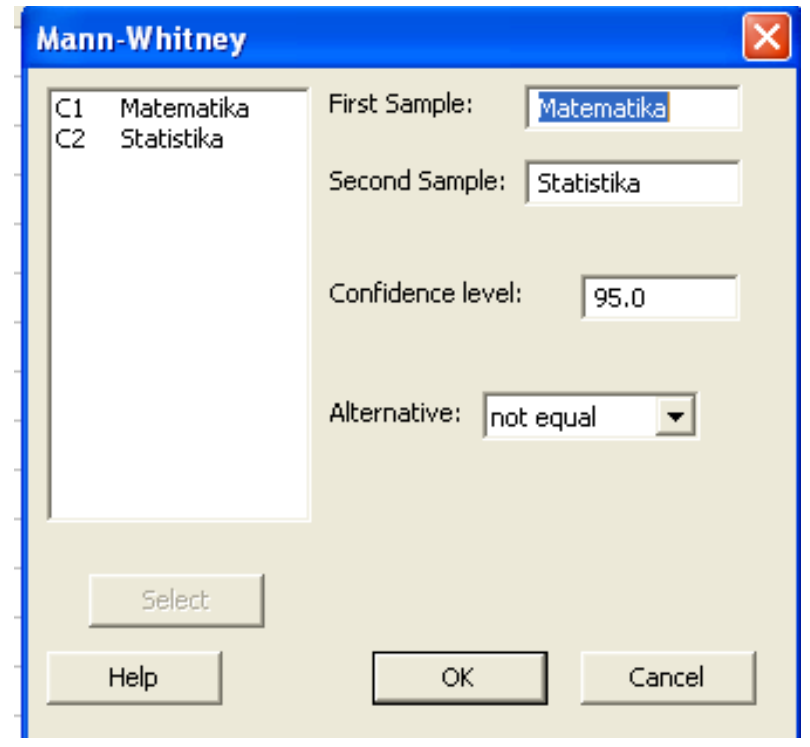

Gambar 10.38

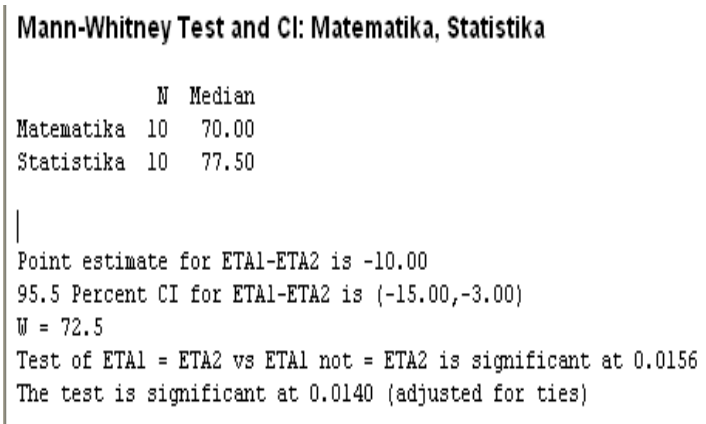

\section{Gambar 10.39}

Berdasarkan Gambar 10.39, diketahui nilai $W=72,5$, di mana nilai tersebut merupakan jumlah ranking nilai ujian matakuliah kalkulus mahasiswa jurusan matematika. Diketahui berdasarkan 
perhitungan sebelumnya, jumlah ranking nilai ujian matakuliah kalkulus mahasiswa jurusan matematika $R(X)$ adalah 72,5 dan jumlah ranking nilai ujian matakuliah kalkulus mahasiswa jurusan statistika $\quad R(Y) \quad$ adalah 137,5, maka $W=$ minimum $(72,5 ; 137,5)=72,5$.Perhatikan juga bahwa diketahui nilai probabilitas (adjusted for ties) adalah $0,014<\alpha=$ 0,05, maka hipotesis nol ditolak dan hipotesis alternatif diterima. Ini berarti pernyataan mengenai "nilai ujian matakuliah kalkulus mahasiswa jurusan statistika berbeda signifikan secara statistika dengan nilai ujian matakuliah kalkulus mahasiswa jurusan matematika" dapat diterima pada tingkat signifikansi 5\%.

\section{PENYELESAIAN DALAM R (UJI MANN-WHITNEY)}

Data terlebih dahulu disimpan dalam Microsoft Excel dengan tipe .CSV (Comma Separeted Values) (Gambar 10.40 dan Gambar 10.41).

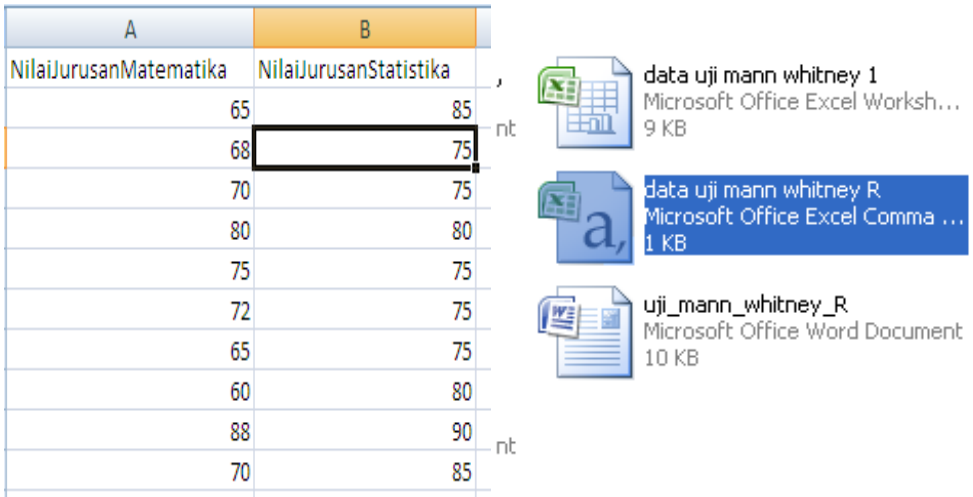


Aktifkan RStudio, kemudian pilih File $=>R$ Script . Ketik perintah R seperti pada Gambar 10.42 .

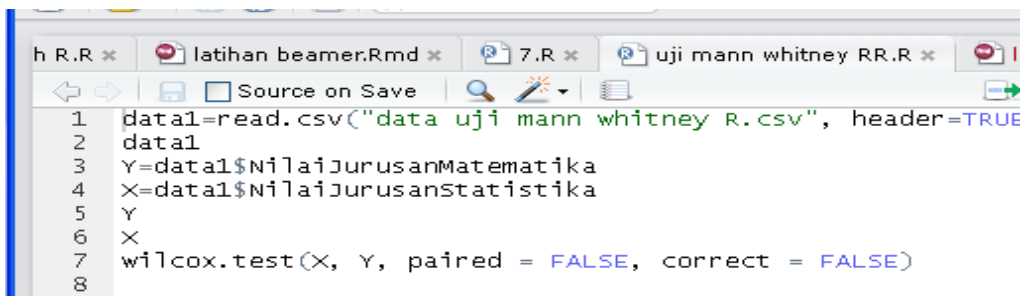

\section{Gambar 10.42}

Selanjutnya pilih Compile, pilih MS Word pada Notebook output format, dan Compile. Berikut hasil berdasarkan berdasarkan R.

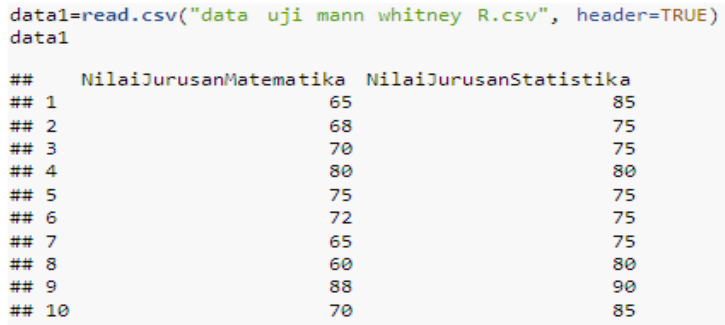

\section{Gambar 10.43}

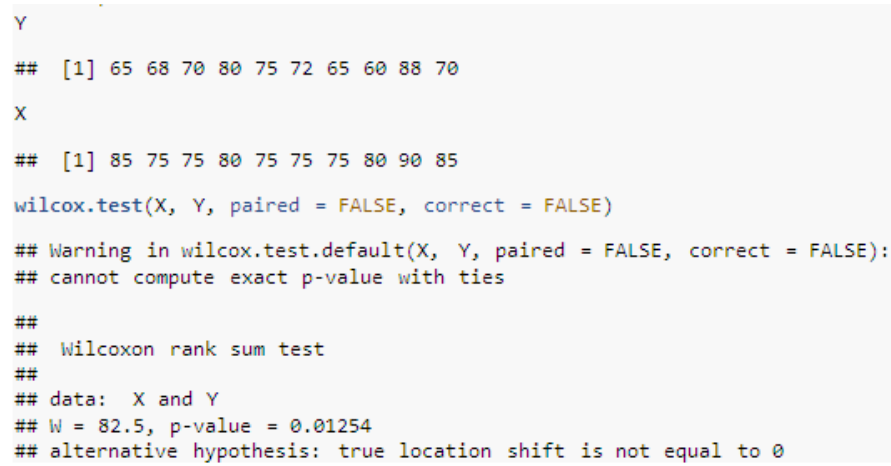

\section{Gambar 10.44}




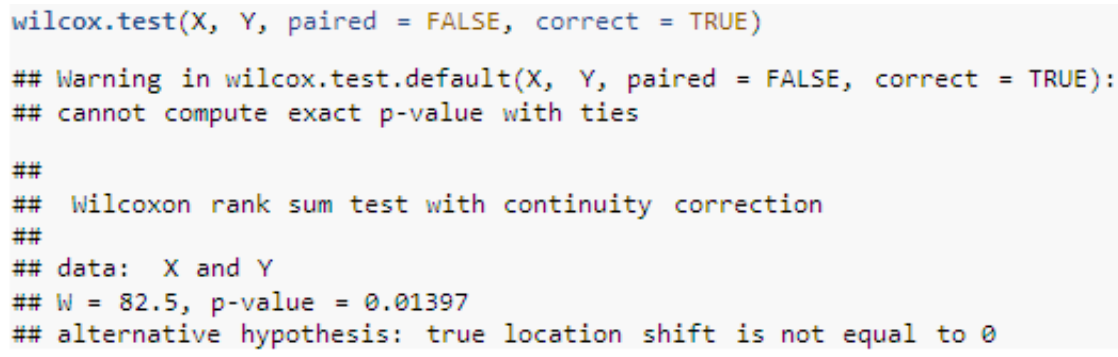

Gambar 10.45

\section{PENYELESAIAN DALAM SPSS (UJI McNEMAR)}

Bangun data dalam SPSS seperti pada Gambar 10.46. Pada Variable View, bentuk variabel Sebelum dan Sesudah. Kemudian atur tipe data (Type) dengan Numeric. Untuk variabel Sebelum, beri Value 0 untuk Label "tidak menggunakan bumbu masakan A", dan Value 1 untuk Label "menggunakan bumbu masakan A". Begitu juga pada variabel Sesudah, beri Value 0 untuk Label "tidak menggunakan bumbu masakan A", dan Value 1 untuk Label "menggunakan bumbu masakan A". Kemudian aktifkan Data View. Input data pada Data View seperti pada Gambar 10.46. Pilih Analyze $\Rightarrow$ Nonparametric Tests $\Rightarrow 2$ Related Samples(Gambar 10.47), sehingga muncul kotak dialog Two Related Samples Test (Gambar 10.48). Variabel Sebelum dimasukkan pada Variablel dan variabel Sesudah dimasukkan pada Variable2. Pada Test Type pilih McNemar dankemudian pilih OK. 


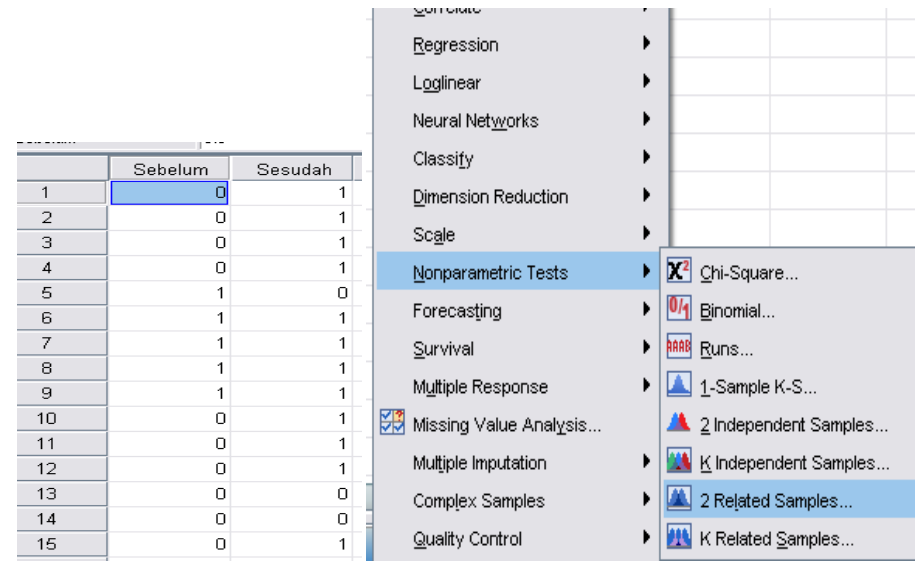

\section{Gambar 10.46 Gambar 10.47}

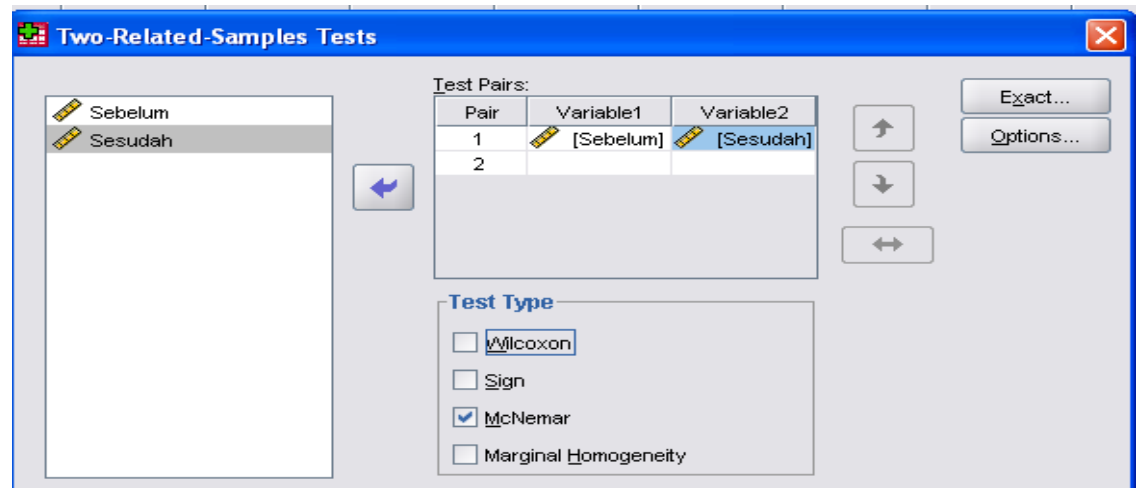

\section{Gambar 10.48}

\section{Tabel 10.8}

\section{Sebelum \& Sesudah}

\begin{tabular}{|l|r|r|}
\hline \multirow{2}{*}{} & \multicolumn{2}{|c|}{ Sesudah } \\
\cline { 2 - 3 } Sebelum & \multicolumn{1}{|c|}{$\begin{array}{c}\text { tidak } \\
\text { menggunakan } \\
\text { bumbu masakan A }\end{array}$} & $\begin{array}{c}\text { menggunakan } \\
\text { bumbu masakan A }\end{array}$ \\
\hline $\begin{array}{l}\text { tidak menggunakan bumbu } \\
\text { masakan A } \\
\text { menggunakan bumbu masakan }\end{array}$ & 2 & 8 \\
A & & \\
\hline
\end{tabular}

Berdasarkan Tabel 10.8 (Tabel Sebelum \& Sesudah), Diketahui terdapat 4 orang menggunakan bumbu masakan merek A sebelum 
dan setelah adanya iklan promosi. Terdapat 8 orang yang tidak menggunakan bumbu masakan merek A sebelum ada iklan promosi. Namun, setelah ada iklan promosi, maka 8 orang tersebut beralih untuk menggunakan bumbu masakan merek A. Tabel tersebut merupakan tabel kontingensi berukuran $2 \times 2$ (dua baris dan dua kolom).Berdasarkan Tabel 10.9 (Tabel Test Statistics) diketahui nilai Exact Sig. (2-tailed) 0,039. Nilai tersebut merupakan nilai statistik dari uji $\operatorname{McNemar}\left(T_{2}\right)$ yang dihitung dengan rumus

$$
T_{2}=2\left[\sum_{i=0}^{X}\left(\begin{array}{l}
n \\
i
\end{array}\right) p^{i} q^{n-i}\right]
$$

Karena nilai Exact Sig. (2-tailed), yakni 0,039, lebih kecil dari tingkat signifikansi $\alpha=0,05$, maka hipotesis nol ditolak dan hipotesis alternatif diterima. Hal ini berarti terdapat pengaruh yang signifikan secara statistika pada penggunaan bumbu masakan mereka A, setelah adanya iklan promosi pada tingkat signifikansi $5 \%$.

\section{Tabel 10.9}

\section{Test Statistics $^{\mathrm{b}}$}

\begin{tabular}{|l|r|}
\hline & \multicolumn{2}{|c|}{$\begin{array}{c}\text { Sebelum \& } \\
\text { Sesudah }\end{array}$} \\
\hline $\mathrm{N}$ & 15 \\
Exact Sig. (2-tailed) & $.039^{\mathrm{a}}$ \\
\hline
\end{tabular}

a. Binomial distribution used.

b. McNemar Test 


\section{PENYELESAIAN DALAM Minitab (UJI McNEMAR)}

Aktifkan terlebih dahulu software Minitab (Gambar 10.49).

Kemudian pilih Calc $\Rightarrow$ Probability Distributions $=>$ Binomial (Gambar 10.50).

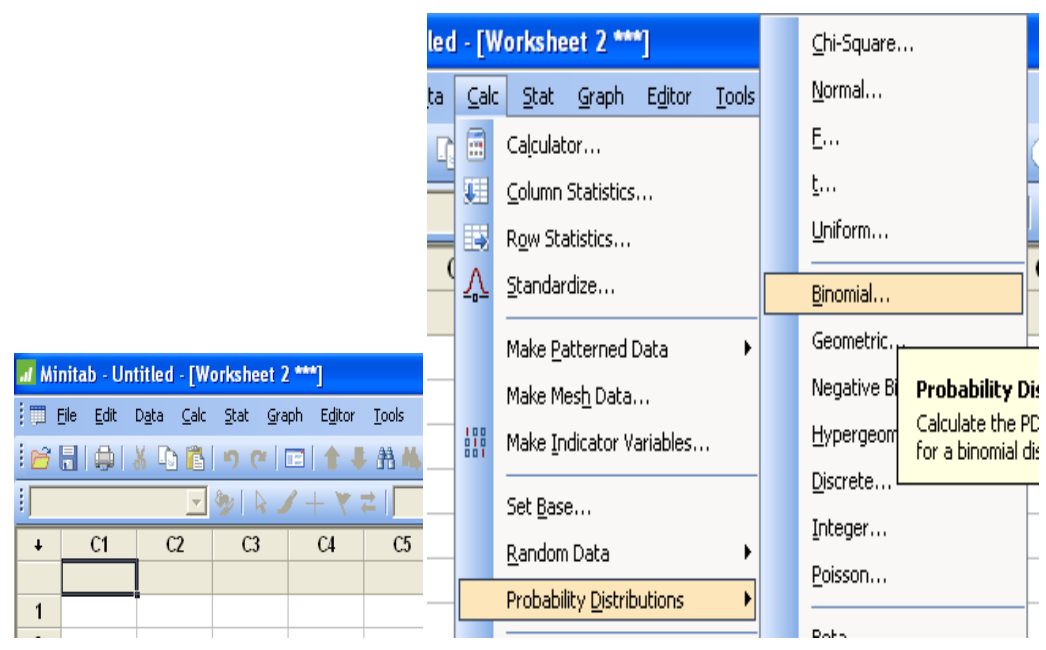

\section{Gambar 10.49}

\section{Gambar 10.50}

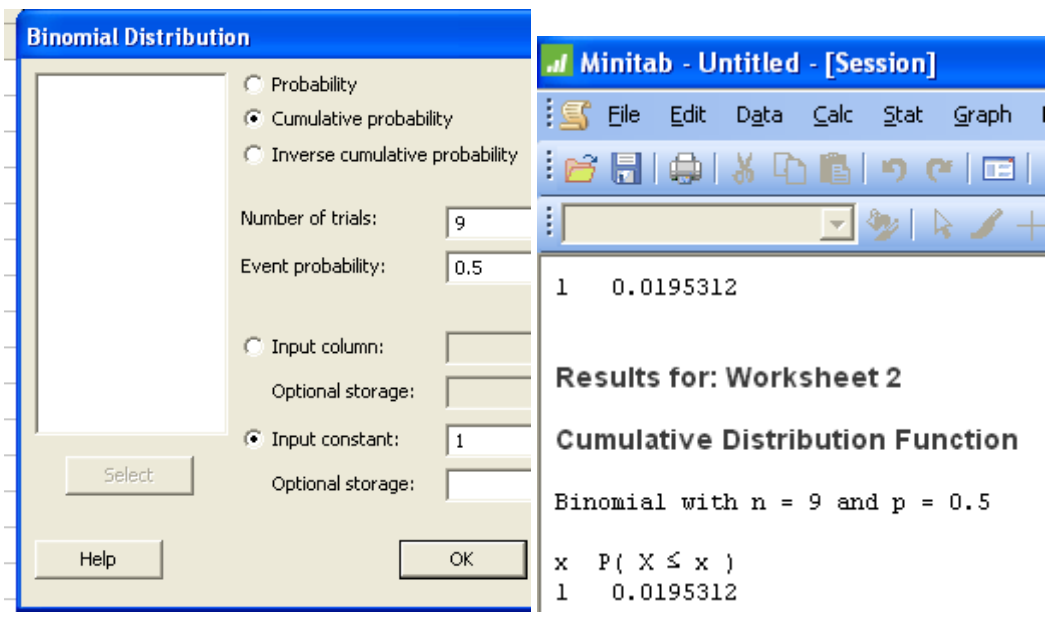

Gambar 10.51

Gambar 10.52 


$$
2 \times 0,0195312=0,0390624 .
$$

Berdasarkan perhitungan di atas diperoleh nilai probabilitas ( $p$ value) 0,03906, yakni lebih kecil dari tingkat signifikansi yang digunakan $\alpha=0,05$, maka hipotesis nol ditolak, dan hipotesis alternatif diterima. Nilai $p$-value, yakni 0,03906 diperoleh dari perhitungan berikut (ingat rumus $T_{2}$ ).

\section{PENYELESAIAN DALAM R (UJI MCNEMAR)}

Aktifkan RStudio, kemudian pilih File $=>R$ Script . Ketik perintah R seperti pada Gambar 10.53.

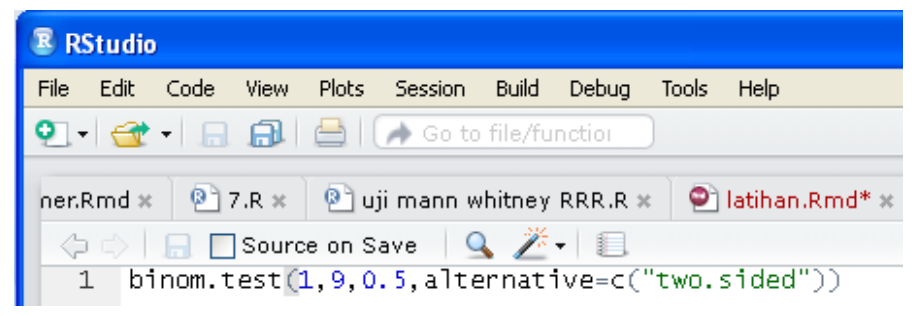

\section{Gambar 10.53}

Selanjutnya pilih Compile, pilih MS Word pada Notebook output format, dan Compile. Berikut hasil berdasarkan berdasarkan R.

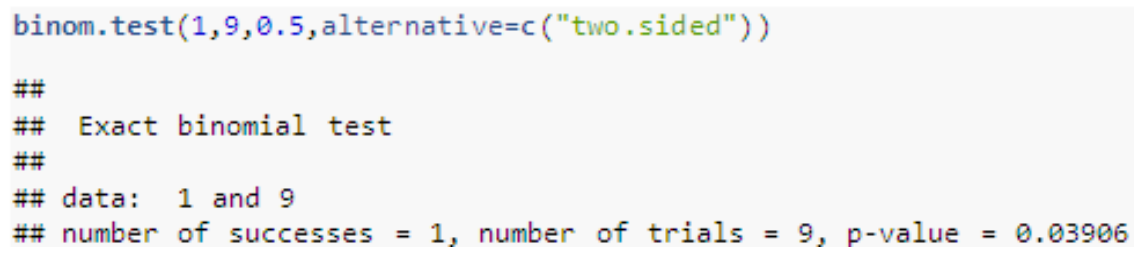

Gambar 10.54 
Berdasarkan Gambar 10.54, diperoleh nilai probabilitas ( $p$-value) 0,03906, yakni lebih kecil dari tingkat signifikansi yang digunakan $\alpha=0,05$, maka hipotesis nol ditolak, dan hipotesis alternatif diterima. Nilai p-value, yakni 0,03906 diperoleh dari perhitungan berikut (ingat rumus $T_{2}$ ).

$$
\begin{gathered}
2\left[\sum_{i=0}^{X}\left(\begin{array}{l}
n \\
i
\end{array}\right) p^{i} q^{n-i}\right]=2[P(X=0)+P(X=1)] \\
=2\left[\left(\begin{array}{l}
9 \\
0
\end{array}\right)\left(\frac{1}{2}\right)^{0}\left(\frac{1}{2}\right)^{9}+\left(\begin{array}{l}
9 \\
1
\end{array}\right)\left(\frac{1}{2}\right)^{1}\left(\frac{1}{2}\right)^{8}\right] \\
=2[0,001953+0,017578] \\
=0,039 .
\end{gathered}
$$

\section{PENYELESAIAN DALAM SPSS (KORELASI SPEARMAN)}

Bangun data dalam SPSS seperti pada Gambar 5.1. Pada Variable View, bentuk variabel Jam dan IP. Kemudian atur tipe data (Type) dengan Numeric. Untuk variabel IP, atur Decimals dengan 1, karena terdapat 1 angka di belakang koma. Kolom Label berfungsi untuk memberi keterangan. Pilih Analyze $=>$ Correlate $\Rightarrow$ Bivariate (Gambar 10.56), sehingga muncul kotak dialog Bivariate Correlations (Gambar 10.57). Variabel Jam dan IPdimasukkan pada kotak Variables. Pada Correlation Coefficients,pilih Spearman. Pada Test of Significance,pilih TwoTailed,karena pengujian hipotesis dilakukan dua arah. Kemudian pilih Flag Significant Correlations dan pilih OK. 


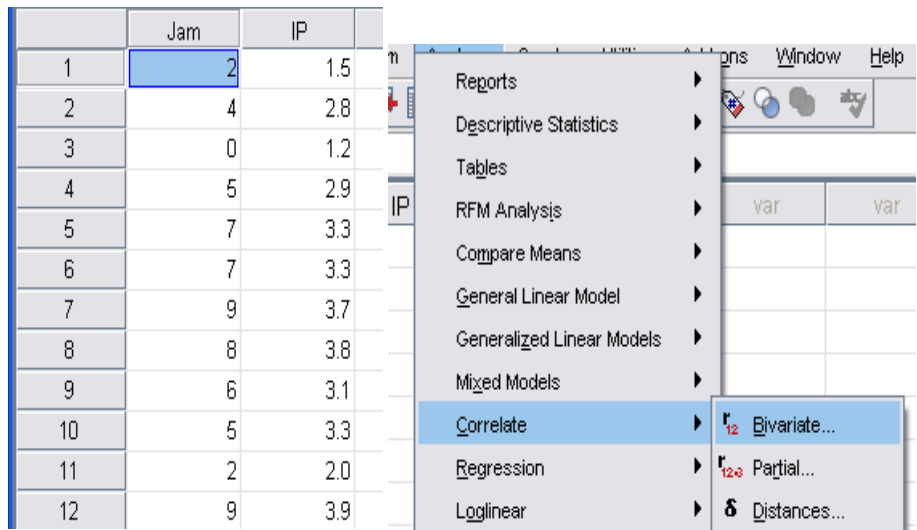

\section{Gambar 10.55 Gambar 10.56}

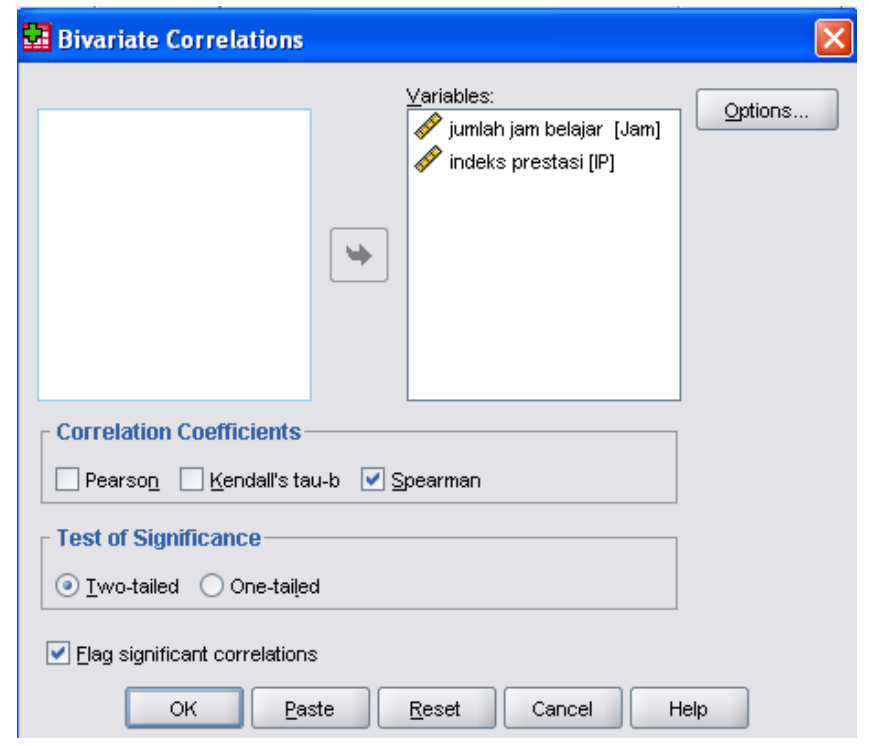

Gambar 10.57

Berdasarkan Tabel 10.10 (Tabel Correlation), diketahui nilai korelasi berperingkat Spearman adalah 0,942. Diketahui juga bahwa nilai probabilitasdari uji tatau Sig.(2-tailed)adalah 0,000. Karena nilai probabilitaslebih kecil dari nilai tingkat signifikansi, yakni 0,05, maka hipotesis nol ditolak dan hipotesis alternatif diterima. Hal ini berarti terdapat hubungan yang signifikan secara 
statistika antara jumlah jam belajar di luar waktu kuliah dalam sehari dengan nilai indeks prestasi mahasiswa pada tingkat signifikansi $5 \%$.

\section{Tabel 10.10}

Correlations

\begin{tabular}{|c|c|c|c|c|}
\hline & & & $\begin{array}{c}\text { jumlah jam } \\
\text { belajar dalam } \\
\text { sehari }\end{array}$ & $\begin{array}{l}\text { indeks } \\
\text { prestasi }\end{array}$ \\
\hline \multirow[t]{6}{*}{$\begin{array}{l}\text { Spearman's } \\
\text { rho }\end{array}$} & \multirow[t]{3}{*}{$\begin{array}{l}\text { jumlah jam belajar } \\
\text { dalam sehari }\end{array}$} & $\begin{array}{l}\text { Correlation } \\
\text { Coefficient }\end{array}$ & 1.000 & $.942^{* *}$ \\
\hline & & Sig. (2-tailed) & & .000 \\
\hline & & $\mathrm{N}$ & 12 & 12 \\
\hline & \multirow[t]{3}{*}{ indeks prestasi } & $\begin{array}{l}\text { Correlation } \\
\text { Coefficient }\end{array}$ & $.942^{* * *}$ & 1.000 \\
\hline & & Sig. (2-tailed) & .000 & \\
\hline & & $\mathrm{N}$ & 12 & 12 \\
\hline
\end{tabular}

**. Correlation is significant at the 0.01 level (2-tailed).

Tabel 10.11

\begin{tabular}{|c|c|c|c|c|}
\hline & & & $\begin{array}{c}\text { jumlah jam } \\
\text { belajar }\end{array}$ & $\begin{array}{l}\text { indeks } \\
\text { nrestasi }\end{array}$ \\
\hline \multirow[t]{6}{*}{ Spearman's rho } & jumlah jam belajar & Correlation Coefficient & \multicolumn{2}{|c|}{0.9418121247825694} \\
\hline & & Sig. (2-tailed) & . & .000 \\
\hline & & N & 12 & 12 \\
\hline & \multirow[t]{3}{*}{ indeks prestasi } & Correlation Coefficient & $.942^{x \pi}$ & 1.000 \\
\hline & & Sig. (2-tailed) & .000 & \\
\hline & & $N$ & 12 & 12 \\
\hline
\end{tabular}

**. Correlation is significant at the 0.01 level (2-tailed)

\begin{tabular}{|c|c|c|c|c|}
\hline \multicolumn{5}{|c|}{ Correlations } \\
\hline & & & $\begin{array}{c}\text { jumlah jam } \\
\text { belajar }\end{array}$ & $\begin{array}{l}\text { indeks } \\
\text { prestasi }\end{array}$ \\
\hline \multirow[t]{6}{*}{ Spearman's rho } & \multirow[t]{3}{*}{ jumlah jam belajar } & Correlation Coefficient & 1.000 & $.942^{\pi \pi}$ \\
\hline & & Sig. (2-tailed) & & .000 \\
\hline & & $N$ & 12 & 12 \\
\hline & \multirow[t]{3}{*}{ indeks prestasi } & Correlation Coefficient & $.942^{\pi \star}$ & 1.000 \\
\hline & & Sig. (2-tailed) & \multicolumn{2}{|c|}{$4.7623620221949734 \mathrm{E}-6$} \\
\hline & & $\mathrm{N}$ & 12 & 12 \\
\hline
\end{tabular}




\section{PENYELESAIAN DALAM R (KORELASI SPEARMAN)}

Data terlebih dahulu disimpan dalam Microsoft Excel dengan tipe .CSV (Comma Separeted Values) (Gambar 10.58 dan Gambar 10.59).

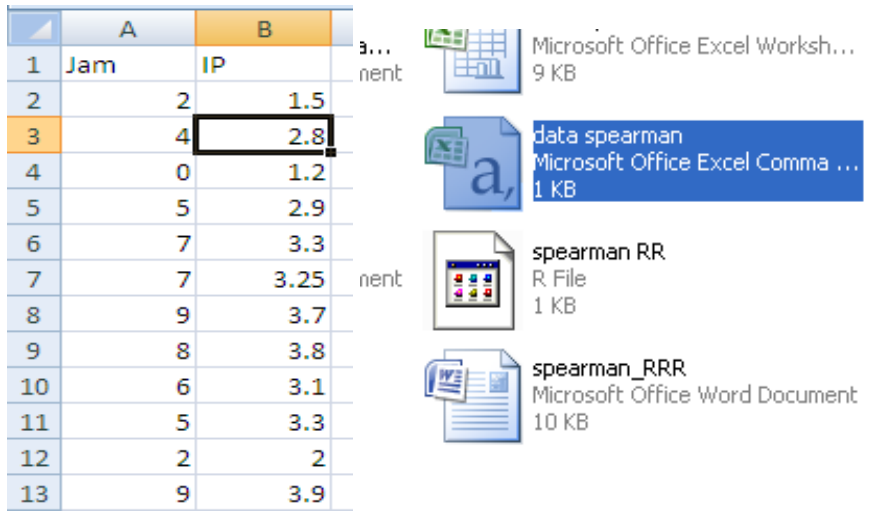

\section{Gambar 10.58}

Gambar 10.59

Aktifkan RStudio, kemudian pilih File $=>R$ Script . Ketik perintah R seperti pada Gambar 10.60 .

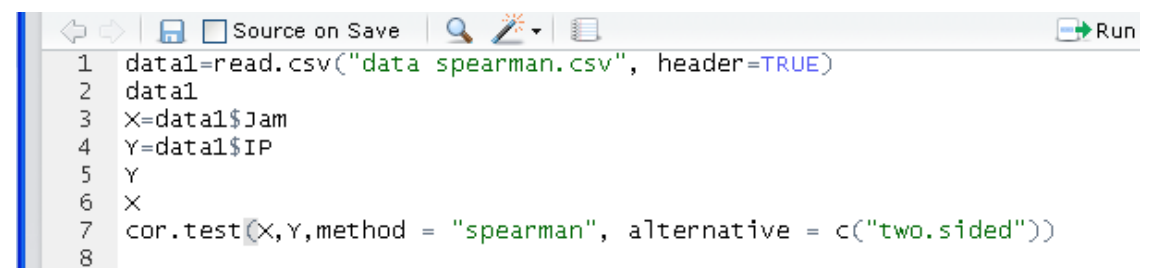

\section{Gambar 10.60}

Selanjutnya pilih Compile, danpilih MS Word pada Notebook output format. Gambar 10.61 dan Gambar 10.62 merupakan hasil berdasarkan R. Berdasarkan Tabel 10.11 diketahui nilai korelasi berperingkat Spearman (rho) adalah 0,9418121. Diketahui juga bahwa nilai probabilitasdari uji $t$ (p-value) adalah $\frac{4.762}{10^{6}}=$ 
0,000004762 . Karena nilai probabilitaslebih kecil dari nilai tingkat signifikansi, yakni 0,05, maka hipotesis nol ditolak dan hipotesis alternatif diterima.

\begin{tabular}{|c|c|c|}
\hline$\# \#$ & Jam & IP \\
\hline$\# \# 1$ & 2 & 1.50 \\
\hline$\# \# 2$ & 4 & 2.80 \\
\hline$\# \# 3$ & 0 & 1.20 \\
\hline$\# \# 4$ & 5 & 2.90 \\
\hline$\# \# 5$ & 7 & 3.30 \\
\hline$\# \# 6$ & 7 & 3.25 \\
\hline$\# \# 7$ & 9 & 3.70 \\
\hline$\# \# 8$ & 8 & 3.80 \\
\hline$\# \# 9$ & 6 & 3.10 \\
\hline \#\#10 & 5 & 3.30 \\
\hline \#\#11 & 2 & 2.00 \\
\hline$\# \# 12$ & 9 & 3.90 \\
\hline
\end{tabular}

Gambar 10.61

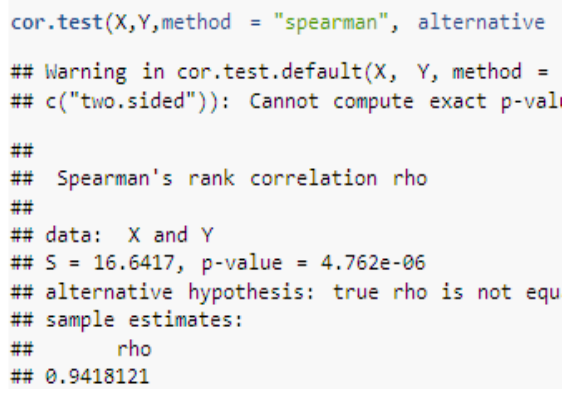

Gambar 10.62

\section{PENYELESAIAN DALAM SPSS (UJI KRUSKAL-WALLIS)}

Bangun data dalam SPSS seperti pada Gambar 10.63. Pada Variable View, bentuk variabel Jumlah dan Bimbel (bimbingan belajar). Untuk variabel Bimbel, beri Value 1 untuk Label "bimbingan belajar A", beri Value 2 untuk Label "bimbingan belajar B", dan beri Value 3 untuk Label "bimbingan belajar C". Kemudian aktifkan Data View. Input data pada Data View seperti pada Gambar 10.63. Pilih Analyze $\Rightarrow>$ Nonparametric Tests $\Rightarrow K$ Independent Samples(Gambar 10.64), sehingga muncul kotak dialog Test for Several Independent Samples (Gambar 10.65). Pada Gambar 10.65, pilih Kruskal-Wallis $H$ pada Test Type. Kemudian variabel jumlah dimasukkan pada Test Variable List dan variabel Bimbel dimasukkan pada Grouping 
Variable.Selanjutnya pilih Define Group. Isi Minimum dengan nilai 1 dan Maximum dengan nilai 3. Perhatikan bahwa nilai 1 (nilai Value yang paling minimum) berarti Label untuk bimbingan belajar A,sedangkan nilai 3 (nilai Value yang paling maksimum) berarti Label untuk bimbingan belajar $\mathbf{C}$. Selanjutnya pilih Continue dan OK.

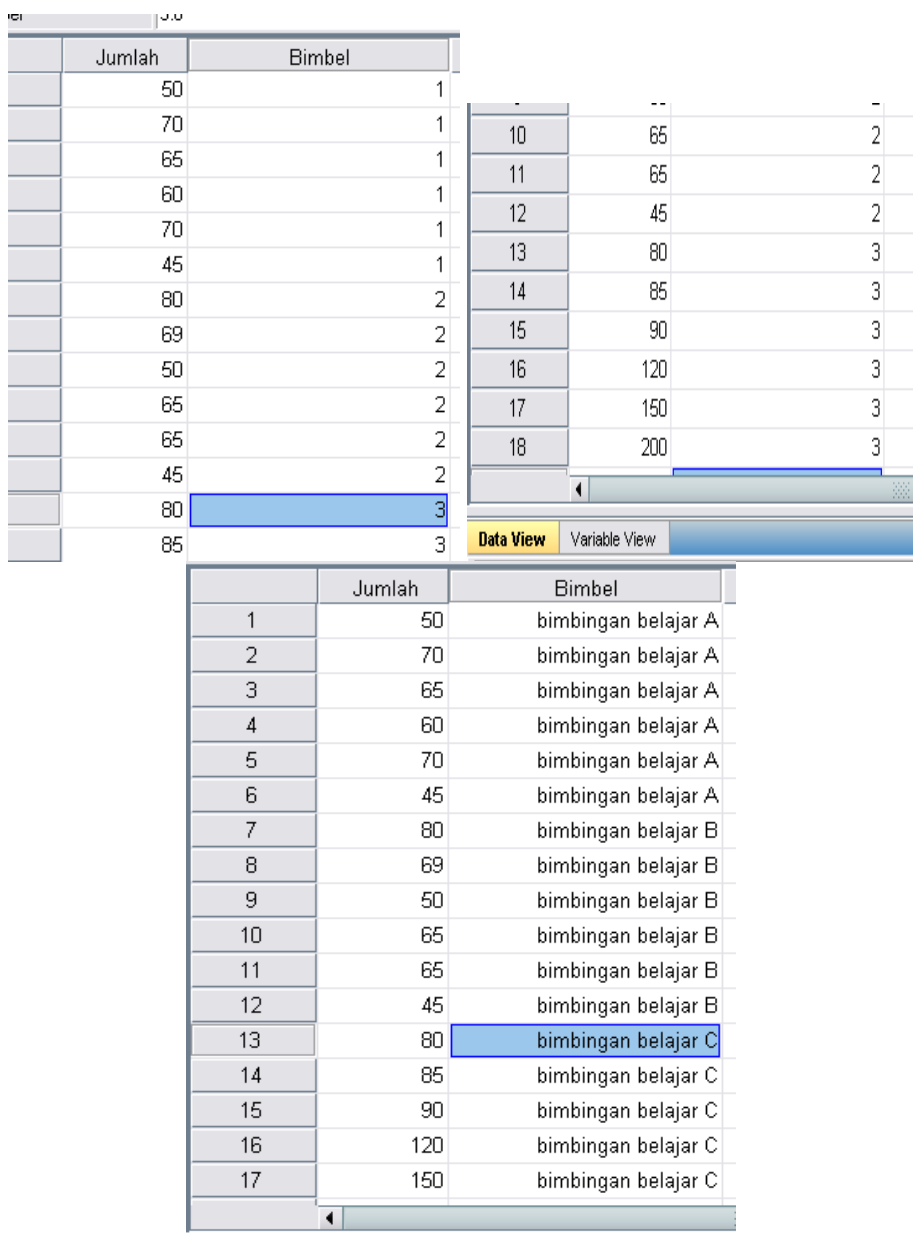

Gambar 10.63 


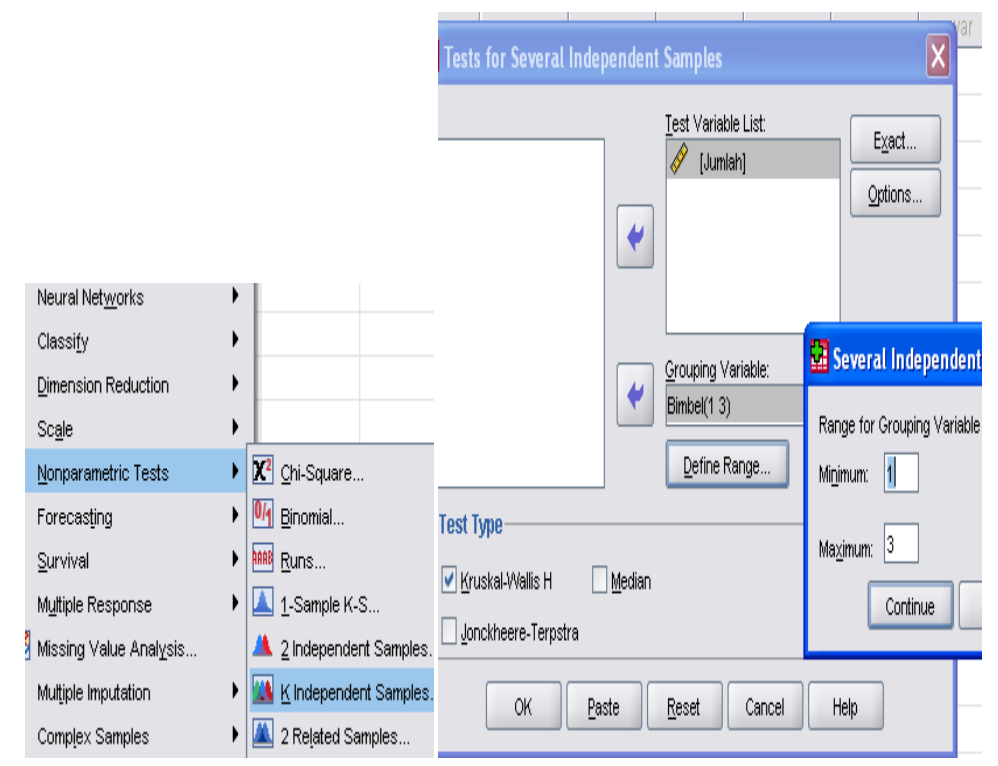

Gambar 10.64 Gambar 10.65

Hasil berdasarkan SPSS disajikan pada Tabel 10.11 (Tabel Ranks). Berdasarkan Tabel 10.11 untuk kolom Mean Rank, diketahui rata-rata ranking dari bimbingan belajar A adalah 6,33. Nilai tersebut merupakan hasil bagi antara jumlah rankingpada bimbingan belajar A, yakni 38 dengan banyaknya elemen sampel bimbingan belajar A yakni, 6.

Pada Tabel10.12 (Tabel Test Statistics), diketahui nilai statistik dari Kruskal-Wallis $(H)$ atau Chi Squareadalah 11,165 dan nilai probabilitas dari uji Kruskal-Wallis (Asymp. Sig.) adalah 0,004. Oleh karena nilai probabilitas, yakni 0,004, lebih kecildibandingkan tingkat signifikansi $\alpha=0,05$, maka hipotesis nol ditolak dan hipotesis alternatif diterima. Hal ini berarti terdapat perbedaan kualitas yang signifikan secara statistika di 
antara ketiga bimbingan belajar tersebut pada tingkat signifikansi $5 \%$.

Tabel 10.11

\begin{tabular}{|c|c|c|}
\hline Bimbel & $\mathrm{N}$ & Mean Rank \\
\hline bimbingan belajar $\mathrm{A}$ & 6 & 6.33 \\
\hline bimbingan belajar B & 6 & 6.75 \\
\hline bimbingan belajar $\mathrm{C}$ & 6 & 15.42 \\
\hline Total & 18 & \\
\hline
\end{tabular}

Tabel 10.12

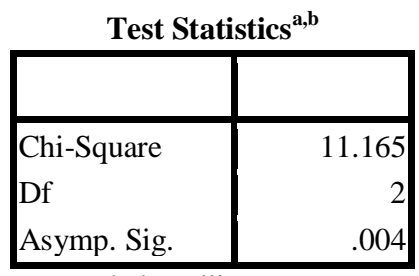

a. Kruskal Wallis Test

b. Grouping Variable: Bimbel

\section{PENYELESAIAN DALAM Minitab (UJI KRUSKAL-} WALLIS)

Bangun data dalam Minitab seperti pada Gambar 10.66. Pilih Stat =>Nonparametrics $=>$ Kruskal-Wallis (Gambar 10.67). Pada Gambar 10.68, pindahkan variabel Jumlah pada Response, dan pindahkan variabel Factor pada Factor. Kemudian pilih OK. Gambar 10.69 merupakan hasil berdasarkan Minitab. Diketahui nilai statistik dari uji Kruskal-Wallis $(\mathrm{H})$ adalah 11,17, derajat bebas (DF) adalah 2, dan probabilitas (P) adalah 0,004. Oleh karena nilai probabilitas, yakni 0,004, lebih kecildibandingkan 
tingkat signifikansi $\alpha=0,05$, maka hipotesis nol ditolak dan hipotesis alternatif diterima. Hal ini berarti terdapat perbedaan kualitas yang signifikan secara statistika di antara ketiga bimbingan belajar tersebut pada tingkat signifikansi 5\%.

\begin{tabular}{|c|r|r|r}
\hline+ & C1 & \multicolumn{1}{c|}{ C2 } & \\
\hline & Jumlah & Bimbel & \\
\hline $\mathbf{2}$ & 70 & 1 & \\
\hline $\mathbf{3}$ & 65 & 1 & \\
\hline $\mathbf{4}$ & 60 & 1 & \\
\hline $\mathbf{5}$ & 70 & 1 & \\
\hline $\mathbf{6}$ & 45 & 1 & \\
\hline $\mathbf{7}$ & 80 & 2 & \\
\hline $\mathbf{8}$ & 69 & 2 & \\
\hline $\mathbf{9}$ & 50 & 2 & \\
\hline $\mathbf{1 0}$ & 65 & 2 & \\
\hline $\mathbf{1 1}$ & 65 & 2 & \\
\hline $\mathbf{1 2}$ & 45 & 2 & \\
\hline $\mathbf{1 3}$ & 80 & 3 & \\
\hline $\mathbf{1 4}$ & 85 & 3 & \\
\hline $\mathbf{1 5}$ & 90 & 3 & \\
\hline $\mathbf{1 6}$ & 120 & 3 & \\
\hline $\mathbf{1 7}$ & 150 & 3 & \\
\hline $\mathbf{1 8}$ & 200 & 3 & \\
\hline $\mathbf{1 9}$ & & & \\
\hline & & & \\
\hline
\end{tabular}

Gambar 10.66

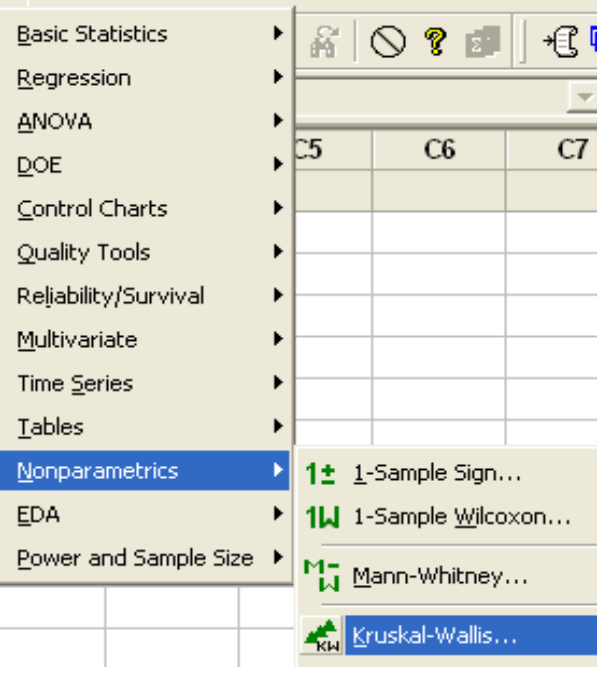

Gambar 10.67

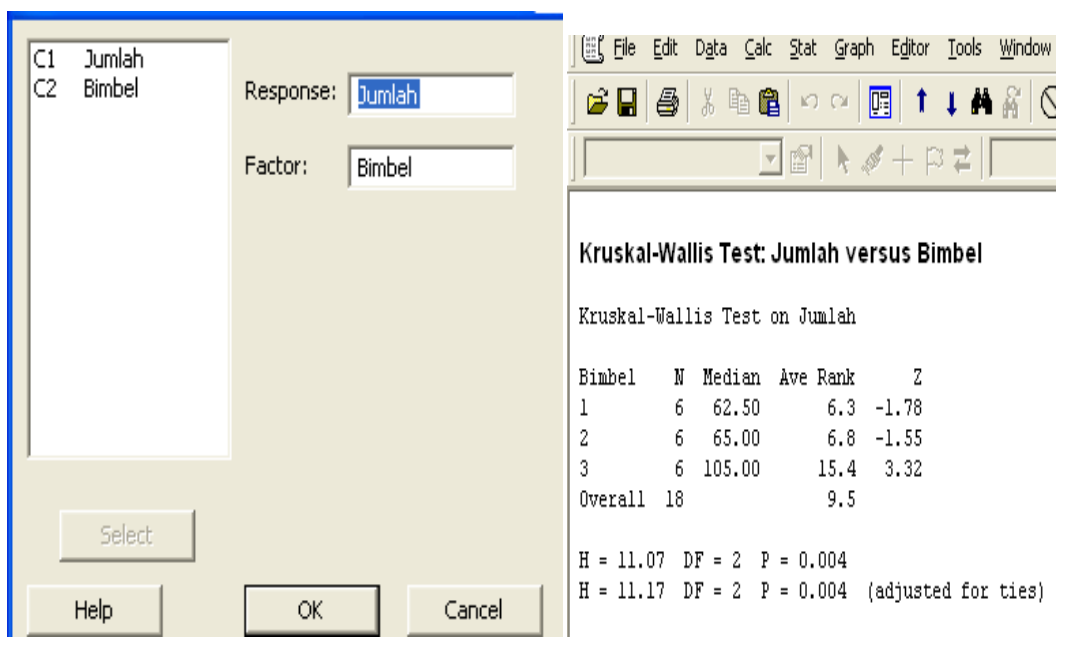

Gambar 10.68

Gambar 10.69 


\section{PENYELESAIAN DALAM R (UJI KRUSKAL-WALLIS)}

Data terlebih dahulu disimpan dalam Microsoft Excel dengan tipe .CSV (Comma Separeted Values) (Gambar 10.70 dan Gambar 10.71).

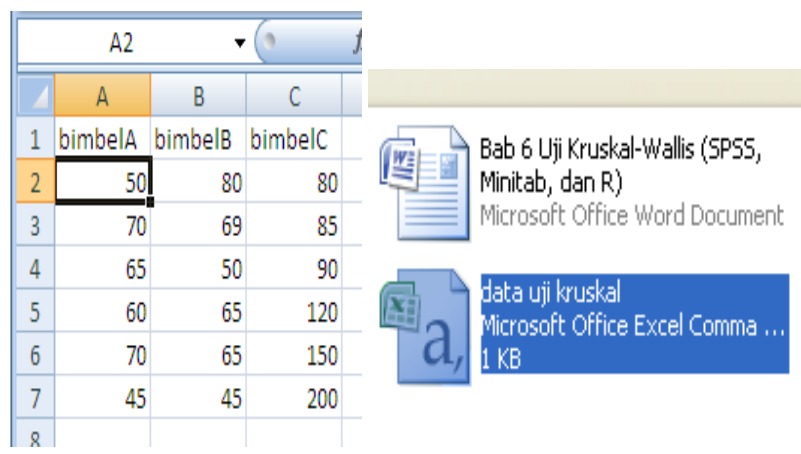

\section{Gambar 10.70 Gambar 10.71}

Aktifkan RStudio, kemudian pilih File $=>R$ Script Ketik perintah R seperti pada Gambar 10.72 .

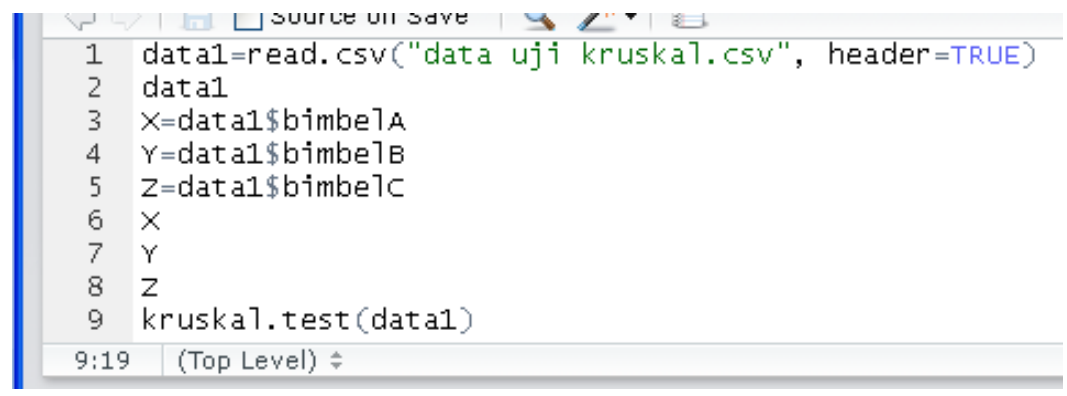

\section{Gambar 10.72}

Selanjutnya pilih Compile, pilih MS Word pada Notebook output format, dan Compile. Berikut hasil berdasarkan berdasarkan R. 


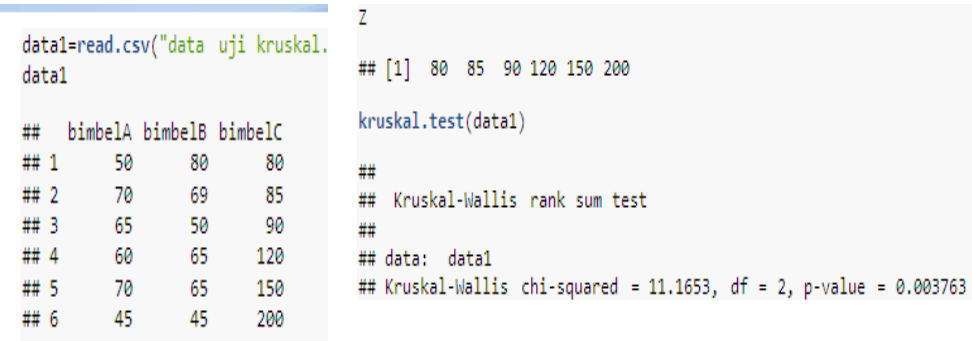

\section{Gambar 10.73}

\section{Gambar 10.74}

Berdasarkan Gambar 6.16, Diketahui nilai statistik dari uji Kruskal-Wallis adalah 11,1653, derajat bebas (df) adalah 2, dan probabilitas (p-value) adalah 0,003763. Oleh karena nilai probabilitas, yakni 0,003763, lebih kecildibandingkan tingkat signifikansi $\alpha=0,05$, maka hipotesis nol ditolak dan hipotesis alternatif diterima.

\section{PENYELESAIAN DALAM SPSS (UJI COCHRAN)}

Bangun data dalam SPSS seperti pada Gambar 10.75. Pada Variable View, bentuk variabel ayam, daging, ikan, dan udang. Kemudian aktifkan Data View. Input data pada Data View seperti pada Gambar 10.75 .

Pilih Analyze $\Rightarrow$ Nonparametric Tests $\Rightarrow K$ Related Samples(Gambar 10.76), sehingga muncul kotak dialog Test for Several Related Samples (Gambar 10.77). Masukkan variabel ayam, daging, ikan dan udang pada kotak Test Variables. Pada Test Type pilih Cochran's $Q$ dan kemudian pilih $\mathrm{OK}$. 


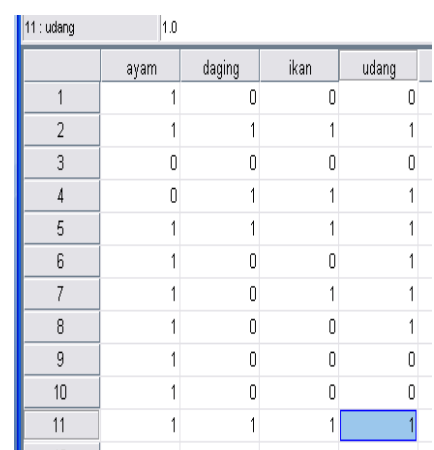

Gambar 10.75

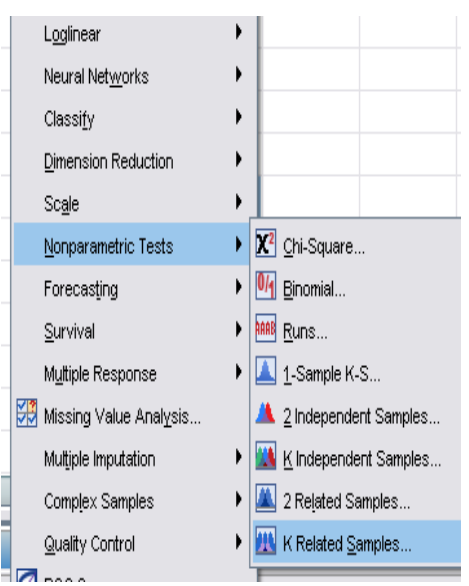

Gambar 10.76

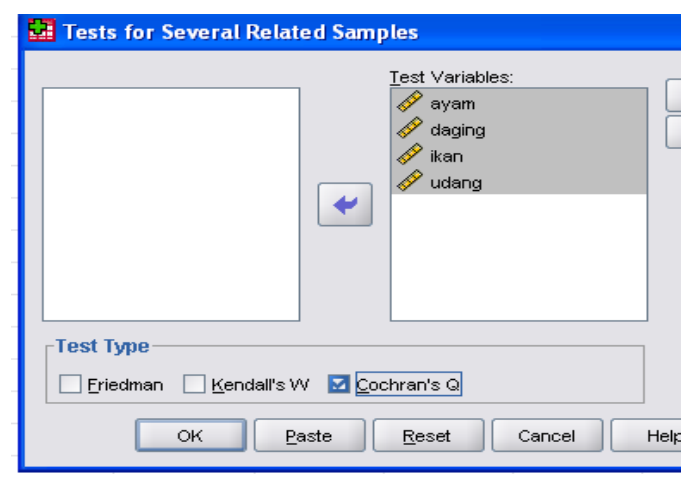

Gambar 10.77

Berdasarkan Tabel 10.13 (Tabel Frequencies) diketahui responden yang suka terhadap kerupuk rasa ayam sebanyak 9 responden, dan responden yang tidak suka rasa ayam sebanyak 2 orang. Responden yang tidak suka terhadap kerupuk rasa daging sebanyak 7 orang dan responden yang suka rasa daging sebanyak 4 orang.Berdasarkan Tabel 10.14 (Tabel Test Statistics) diketahui nilai statistik dari uji Cochran atau Cochran's $Q$ adalah 7,696 atau dibulatkan menjadi 7,70. Diketahui kritis $\operatorname{chi-kuadrat}\left(\chi_{\text {kritis }}^{2}\right)$ adalah 7,815. Perhatikan bahwa karena nilai statistik dari uji 
Cochran, yakni 7,70, lebih kecil dari nilai kritis chi-kuadrat, yakni 7,815, maka hipotesis nol diterima dan hipotesis alternatif ditolak. Hal ini berarti keempat jenis kerupuk memberikan kepuasan rasa yang sama pada tingkat signifikansi $5 \%$.

\section{Tabel 10.13}

\begin{tabular}{|c|c|c|c|}
\hline \multicolumn{4}{|c|}{ Frequencies } \\
\hline & \multicolumn{3}{|c|}{ Value } \\
\hline & 0 & 1 & \\
\hline ayam & & & 9 \\
\hline daging & & & 4 \\
\hline ikan & & & 5 \\
\hline udang & & & 7 \\
\hline
\end{tabular}

\section{Tabel 10.14}

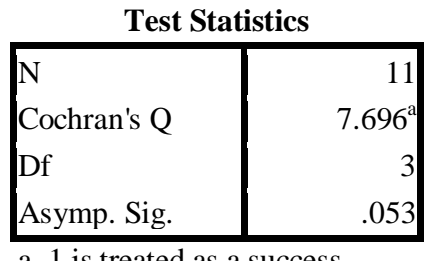

a. 1 is treated as a success.

Selain itu, pengambilan keputusan terhadap hipotesis juga dapat dilakukan dengan membandingkan nilai Asymp. Sig. terhadap tingkat signifikansi. Perhatikan bahwa karena nilai probabilitas(Asymp. Sig.), yakni 0,053, lebih besar dari tingkat signifikansi $\alpha=0,05$, maka hipotesis nol diterima dan hipotesis alternatif ditolak. 


\section{PENYELESAIAN DALAM R (UJI COCHRAN)}

Data terlebih dahulu disimpan dalam Microsoft Excel dengan tipe .CSV (Comma Separeted Values) (Gambar 10.78 dan Gambar 10.79).

\begin{tabular}{|c|c|c|c|c|c|c|c|c|}
\hline 4 & A & & $B$ & C & 4 & A & B & C \\
\hline 1 & Skor & & Jeniskerupuk & Responden & 18 & 0 & 2 & 6 \\
\hline 2 & & 1 & 1 & 1 & 19 & 0 & 2 & 7 \\
\hline 3 & & 1 & 1 & 2 & 20 & 0 & 2 & 8 \\
\hline 4 & & 0 & 1 & 3 & 21 & 0 & 2 & 9 \\
\hline 5 & & 0 & 1 & 4 & 22 & 0 & 2 & 10 \\
\hline 6 & & 1 & 1 & 5 & 23 & 1 & 2 & 11 \\
\hline 7 & & 1 & 1 & 6 & 24 & 0 & 3 & 1 \\
\hline 8 & & 1 & 1 & 7 & 25 & 1 & 3 & 2 \\
\hline 9 & & 1 & 1 & 8 & 26 & 0 & 3 & 3 \\
\hline 10 & & 1 & 1 & 9 & 27 & 1 & 3 & 4 \\
\hline 11 & & 1 & 1 & 10 & 28 & 1 & 3 & 5 \\
\hline 12 & & 1 & 1 & 11 & 29 & 0 & 3 & 6 \\
\hline 13 & & 0 & 2 & 1 & 30 & 1 & 3 & 7 \\
\hline 14 & & 1 & 2 & 2 & 31 & 0 & 3 & 8 \\
\hline 15 & & 0 & 2 & 3 & 32 & 0 & 3 & 9 \\
\hline 16 & & 1 & 2 & 4 & 33 & 0 & 3 & 10 \\
\hline 17 & & 1 & 2 & 5 & 34 & 1 & 3 & 11 \\
\hline \multirow[t]{13}{*}{141} & $1+11$ & data & a uji cochran 1 & Sheet2 Sheet3 & 141 & $M$ dat & cochran 1 & Sheet2 Sheet3 \\
\hline & & & 35 & 0 & & 4 & 1 & \\
\hline & & & 36 & 1 & & 4 & 2 & \\
\hline & & & 37 & 0 & & 4 & 3 & \\
\hline & & & 38 & 1 & & 4 & 4 & \\
\hline & & & 39 & 1 & & 4 & 5 & \\
\hline & & & 40 & 1 & & 4 & 6 & \\
\hline & & & 41 & 1 & & 4 & 7 & \\
\hline & & & 42 & 1 & & 4 & 8 & \\
\hline & & & 43 & 0 & & 4 & 9 & \\
\hline & & & 44 & 0 & & 4 & 10 & \\
\hline & & & 45 & 1 & & 4 & 11 & \\
\hline & & & 46 & & & & & \\
\hline
\end{tabular}

Gambar 10.78 


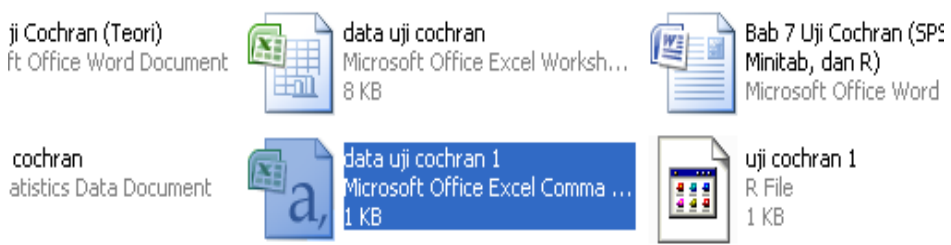

wan 1

\section{Gambar 10.79}

Aktifkan RStudio, kemudian pilih File $=>R$ Script . Ketik perintah R seperti pada Gambar 10.80 .

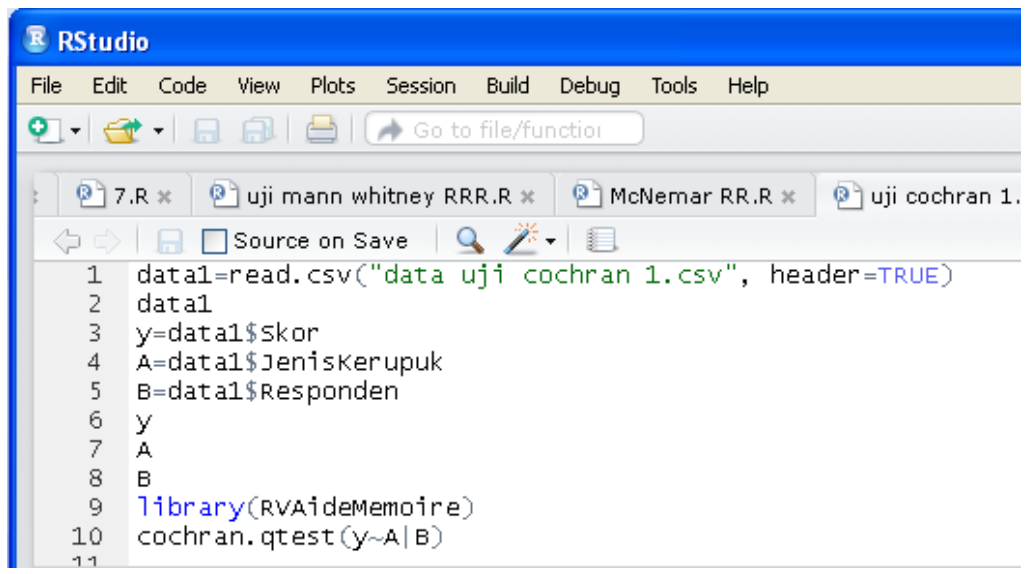

\section{Gambar 10.80}

Selanjutnya pilih Compile, danpilih MS Word pada Notebook output format, dan Compile. Gambar 10.81 merupakan hasil berdasarkan R. Diketahui nilai statistik dari uji Cochran (Q) adalah 7,6957, derajat bebas (df) adalah 3, dan nilai probabilitas (p-value) adalah 0,05274. Perhatikan bahwa karena nilai probabilitas, yakni 0,05274, lebih besar dari tingkat signifikansi $\alpha=0,05$, maka hipotesis nol diterima dan hipotesis alternatif ditolak. 


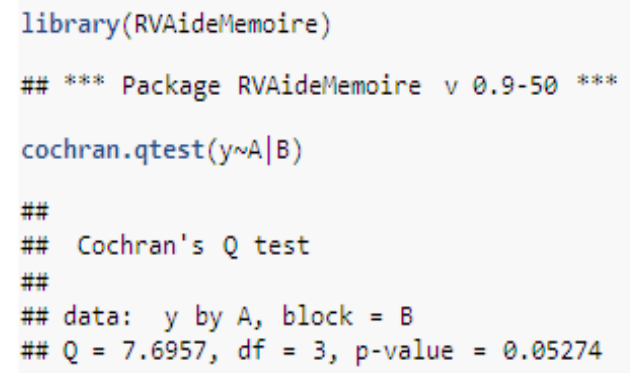

\section{Gambar 10.81}

\section{PENYELESAIAN DALAM SPSS (UJI FRIEDMAN)}

Bangun data dalam SPSS seperti pada Gambar 10.82. Pada Variable View, bentuk variabel ayam, daging, ikan, dan udang. Kemudian aktifkan Data View. Input data pada Data View seperti pada Gambar 10.82.

\begin{tabular}{|c|c|c|c|c|c|c|c|}
\hline & ayam & daging & ikan & udang & & & \\
\hline 1 & 90 & 85 & 83 & 70 & wasonIy & & \\
\hline 2 & 90 & 70 & 77 & 65 & Dimension Reduction & ' & \\
\hline 3 & 75 & 70 & 60 & 85 & Scale & 1 & \\
\hline 4 & 80 & 70 & 75 & 90 & Nonparametric Tests & ' & $\underline{X^{2}}$ Chi-Square... \\
\hline 5 & 90 & 85 & 60 & 89 & Forecasting & ' & $0 / 4$ Binomial... \\
\hline 6 & 60 & 65 & 70 & 85 & Survival & - & 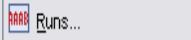 \\
\hline 7 & 65 & 85 & 70 & 90 & Multiple Response & - & $\triangle$ 1-Sample K-S... \\
\hline 8 & 65 & 100 & 60 & 85 & 湔 Missing Value Analysis... & 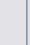 & $\Delta_{2}$ Independert Samples. \\
\hline 9 & 80 & 70 & 75 & 90 & Multiple Imputation & - & KIndependert Samples. \\
\hline 10 & 90 & 70 & 80 & 75 & Complex Samples & , & 2Related Samples... \\
\hline 11 & 75 & 65 & 70 & 64 & & . & Krit Kelated Samples \\
\hline 12 & 80 & 70 & 75 & 90 & Quality Control & $'$ & W. KRelated Samples... \\
\hline
\end{tabular}

\section{Gambar 10.82}

Gambar 10.83

Pilih Analyze $\Rightarrow$ Nonparametric Tests $\Rightarrow K$ Related Samples(Gambar 10.83), sehingga muncul kotak dialog Test for Several Related Samples (Gambar 10.84). Variabel ayam, daging, 
ikan,dan udang dimasukkan pada Test Variables. Pada Test Type pilih Friedman dankemudian pilih OK.

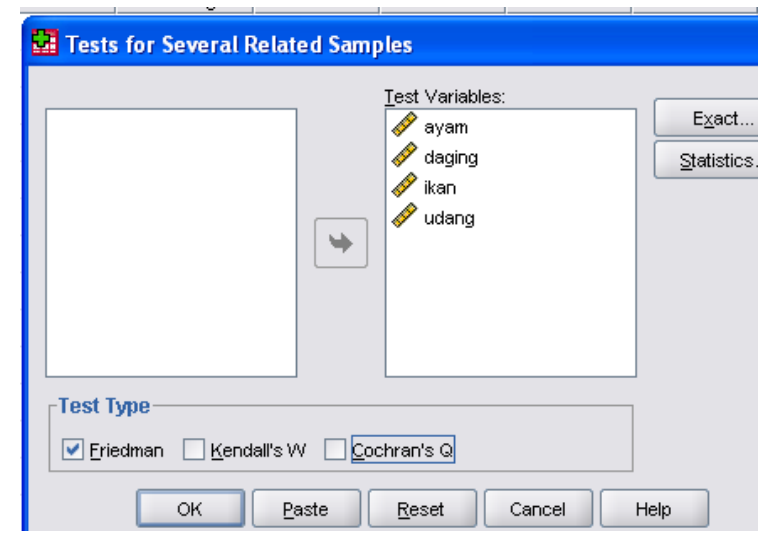

Gambar 10.84

Berdasarkan Tabel 10.15 (Tabel Ranks), padarata-rata rankinguntuk rasa ayam adalah 3, rata-rata rankinguntuk rasa daging 2, rata-rata rankinguntuk rasa ikan 2,08, dan rata-rata rankinguntuk rasa udang 2,92. Hasil perhitungan berdasarkan SPSS sama dengan hasil dengan perhitungan manual sebelumnya.

Berdasarkan Tabel 10.16 (Tabel Test Statistics), diketahui nilai statistik dari uji Friedman atau Chi-Square adalah 6,1. Perhatikan bahwa karena nilai statistik dari uji Friedman, yakni 6,1, lebih kecil dari nilai kritis chi-kuadrat $\left(\chi_{\text {kritis }}^{2}\right)$, yakni 7,815, maka hipotesis nol diterima dan hipotesis alternatif ditolak. Hal ini berarti perbedaan kepuasan di antara keempat jenis kerupuk tidak signifikan secara statistikpada tingkat signifikansi $5 \%$. 
Selain itu, pengambilan keputusan terhadap hipotesis juga dapat dilakukan dengan membandingkan nilai Asymp. Sig.(nilai probabilitas)terhadap tingkat signifikansi. Perhatikan bahwa karena nilai Asymp. Sig., yakni 0,107, lebih besar dari tingkat signifikansi $\alpha=0,05$, maka hipotesis nol diterima dan hipotesis alternatif ditolak.

Tabel 10.15

\begin{tabular}{|l|r|}
\multicolumn{2}{c}{ Ranks } \\
\hline \multicolumn{1}{|c|}{ Mean Rank } \\
\hline Ayam & 3.00 \\
Daging & 2.00 \\
Ikan & 2.08 \\
Udang & 2.92 \\
\hline
\end{tabular}

Tabel 10.16

\begin{tabular}{|l|r|}
\hline \multicolumn{2}{|c|}{ Test Statistics $^{\mathrm{a}}$} \\
\hline $\mathrm{N}$ & 12 \\
Chi-Square & 6.100 \\
Df & 3 \\
Asymp. Sig. & .107 \\
\hline
\end{tabular}

\section{PENYELESAIAN DALAM Minitab (UJI FRIEDMAN)}

Bangun data dalam Minitab seperti pada Gambar 10.85. Bentuk variabel Nilai, Jenis Kerupuk, dan Responden Ke-. Pilih Stat $=>$ Nonparametrics $=>$ Friedman (Gambar 10.86). 


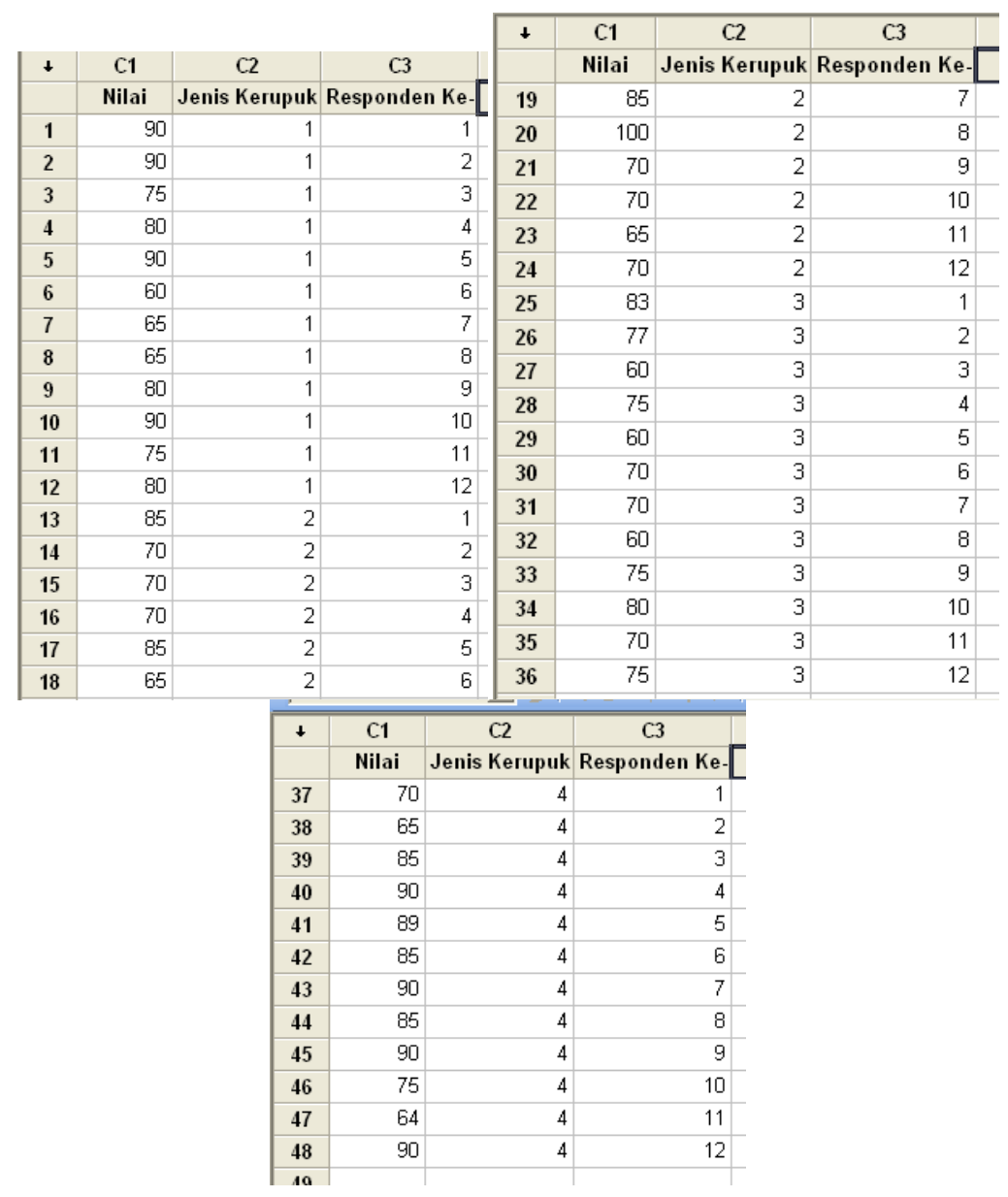

\title{
Gambar 10.85
}

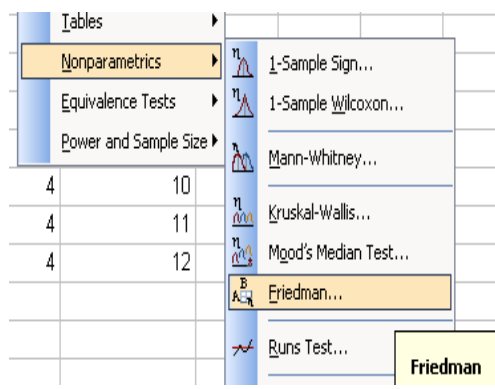

\section{Friedman}

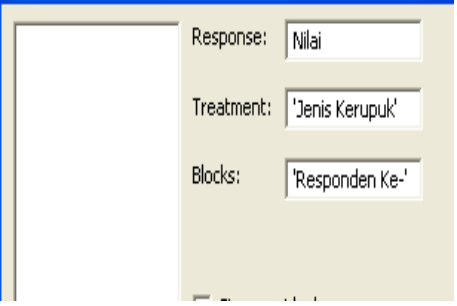

\section{Gambar 10.86}

\author{
Gambar 10.87
}


Pada Gambar 10.87, pindahkan variabel Nilai pada kotak Response, variabel Jenis Kerupuk pada kotak Treatment, dan variabel Responden Ke- pada kotak Blocks. Kemudian pilih OK. Gambar 10.88 menyajikan hasil perhitungan berdasarkan Minitab. Diketahui nilai statistik dari uji Friedman (S) adalah 6,10, derajat bebas (DF) adalah 3, dan nilai probabilitas (P) adalah 0,107.

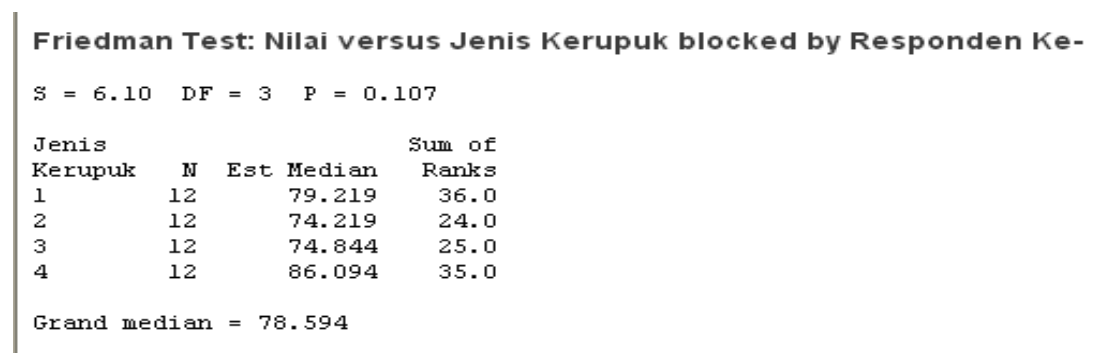

Gambar 10.88

\section{PENYELESAIAN DALAM R (UJI FRIEDMAN)}

Data terlebih dahulu disimpan dalam Microsoft Excel dengan tipe .CSV (Comma Separeted Values) (Gambar 10.89 dan Gambar 10.90).

\begin{tabular}{|c|c|c|c|}
\hline 4 & A & B & C \\
\hline 1 & Skor & JenisKerupuk & Responden \\
\hline 2 & 90 & 1 & 1 \\
\hline 3 & 90 & 1 & 2 \\
\hline 4 & 75 & 1 & 3 \\
\hline 5 & 80 & 1 & 4 \\
\hline 6 & 90 & 1 & 5 \\
\hline 7 & 60 & 1 & 6 \\
\hline 8 & 65 & 1 & 7 \\
\hline 9 & 65 & 1 & 8 \\
\hline 10 & 80 & 1 & 9 \\
\hline 11 & 90 & 1 & 10 \\
\hline 12 & 75 & 1 & 11 \\
\hline 13 & 80 & 1 & 12 \\
\hline 14 & 85 & 2 & 1 \\
\hline 15 & 70 & 2 & 2 \\
\hline 16 & 70 & 2 & 3 \\
\hline 17 & 70 & 2 & 4 \\
\hline 144 & $1 M$ dat & ta uji friedman 1 & \\
\hline
\end{tabular}

Gambar 10.89 


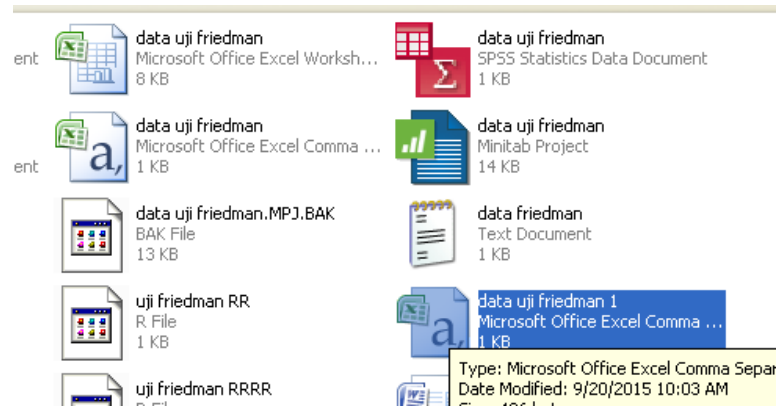

Gambar 10.90

Aktifkan RStudio, kemudian pilih File $=>R$ Script . Ketik perintah R seperti pada Gambar 10.91.

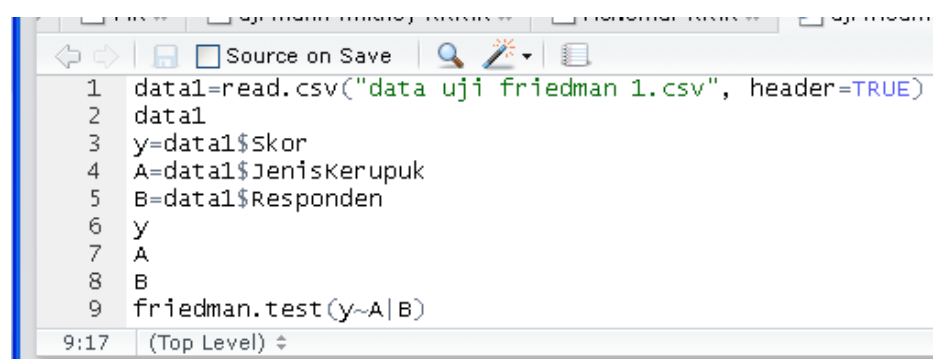

\section{Gambar 10.91}

Selanjutnya pilih Compile, dan pilih MS Word pada Notebook output format, dan Compile. Berikut hasil berdasarkan R.Berdasarkan Gambar 10.93, diketahui nilai statistik dari uji Friedman adalah 6,1, derajat bebas (df) adalah 3, dan nilai probabilitas ( $p$-value) adalah 0,1068. Perhatikan bahwa karena nilai statistik dari uji Friedman, yakni 6,1, lebih kecil dari nilai kritis chi-kuadrat $\left(\chi_{\text {kritis }}^{2}\right)$, yakni 7,815, maka hipotesis nol diterima dan hipotesis alternatif ditolak. Hal ini berarti perbedaan kepuasan di antara keempat jenis kerupuk tidak signifikan secara statistikpada tingkat signifikansi 5\%. Selain itu, pengambilan 
keputusan terhadap hipotesis juga dapat dilakukan dengan membandingkan nilai probabilitas ( $p$-value)terhadap tingkat signifikansi. Perhatikan bahwa karena nilai Asymp. Sig., yakni 0,1068, lebih besar dari tingkat signifikansi $\alpha=0,05$, maka hipotesis nol diterima dan hipotesis alternatif ditolak.

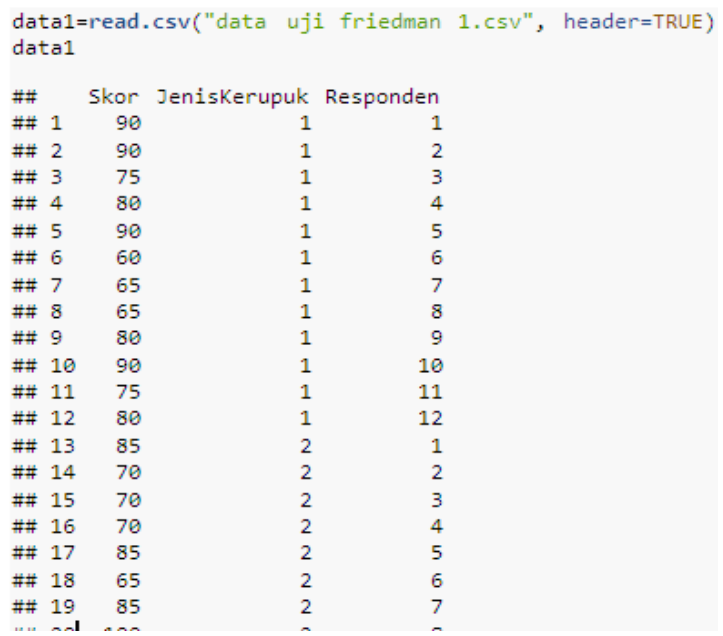

Gambar 10.92

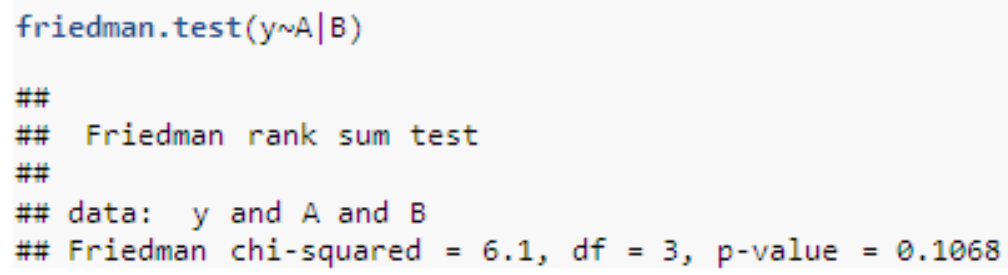

Gambar 10.93 


\section{PENYELESAIAN DALAM SPSS (CHI-KUADRAT 1)}

Bangun data dalam SPSS seperti pada Gambar 10.94. Pada Variable View, bentuk variabel frekuensi dan sisi_angka. Beri Value 1 untuk Label "angka", dan beri Value 0 untuk Label "gambar" (Gambar 10.94). Kemudian aktifkan Data View (Gambar 10.95). Input data pada Data Viewseperti pada Gambar 10.95. Pilih Data $=>$ Weight Cases (Gambar 10.96). Pada Gambar 10.97, aktifkan/bulatkan Weight cases by, kemudian pindahkan variabel frekuensi pada bagian Frequency Variable: dan pilih OK.

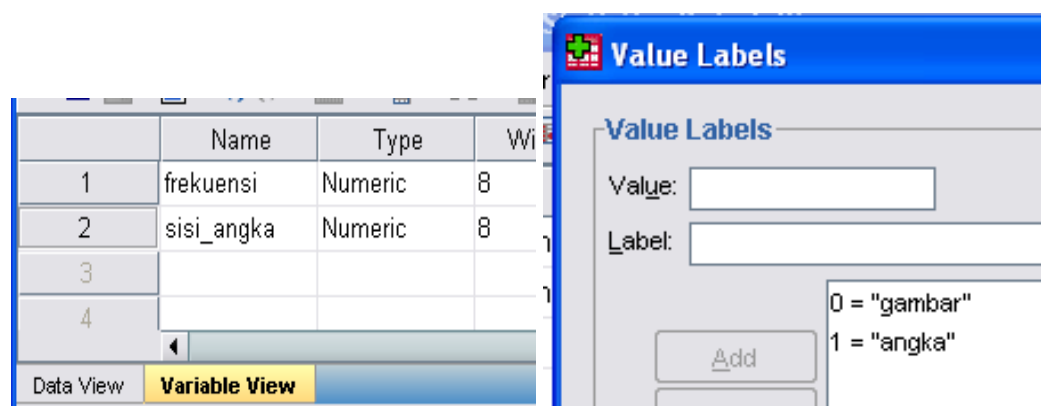

Gambar 10.94
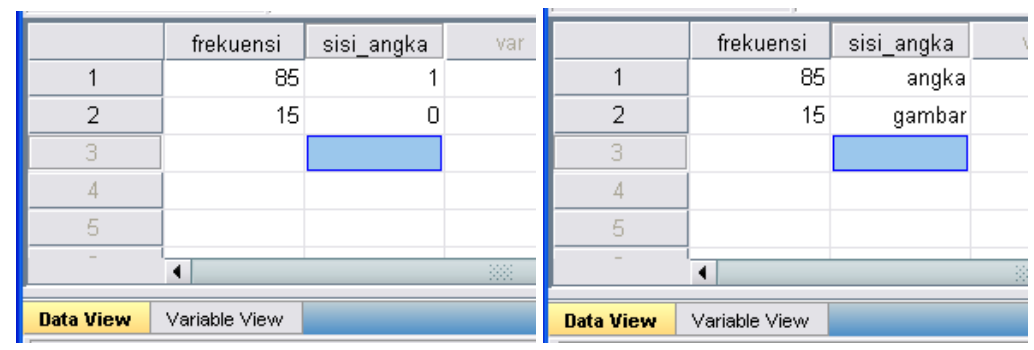

Gambar 10.95 


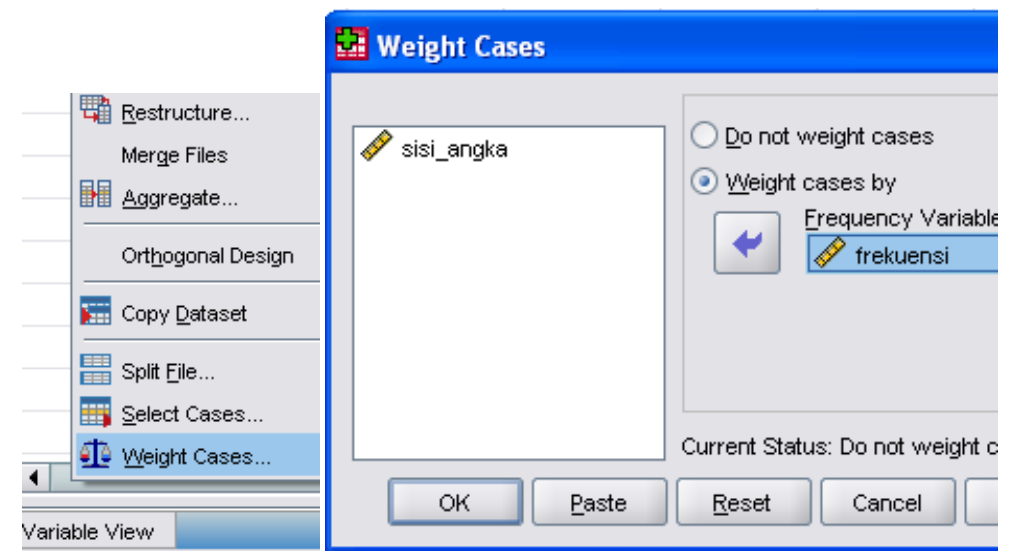

\section{Gambar 10.96}

Gambar 10.97

Pilih Analyze $\Rightarrow>$ Nonparametric Test $\Rightarrow$ Chi Square (Gambar 10.98), sehingga muncul kotak dialog Chi Square Test (Gambar 10.99). Masukkan variabel frekuensi dan sisi_angka pada kotak Test Variable List(Gambar 10.99). Kemudian pilih OK.

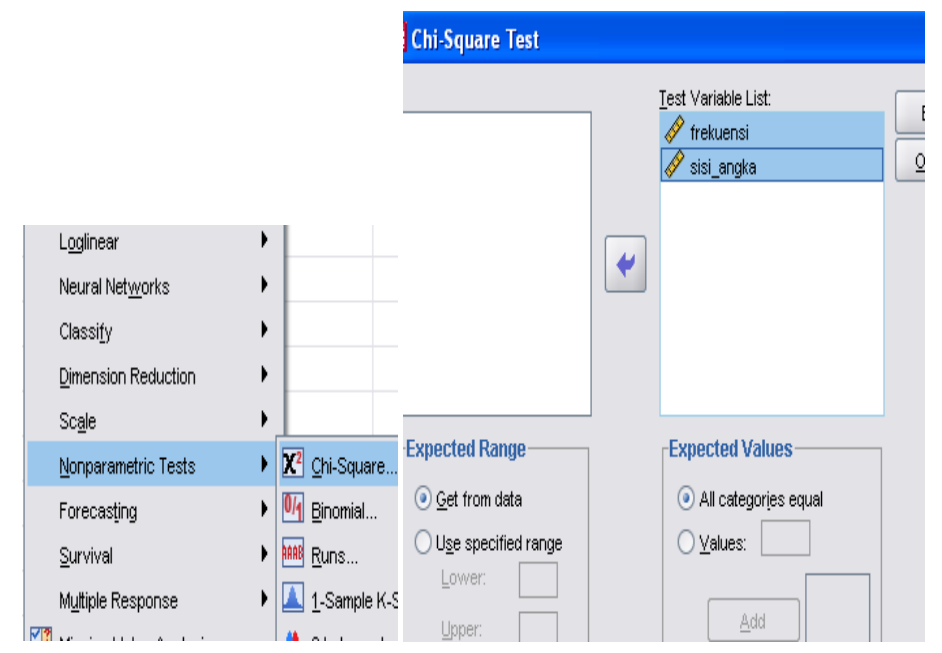

Gambar 10.98

Gambar 10.99

Berdasarkan Tabel 10.17 (Tabel frekuensi),pada kolom Observed Nmenyajikan frekuensi pengamatan, yakni untuk sisi angka 
muncul sebanyak 85 kali dan untuk sisi gambar sebanyak 15 kali. Pada kolom Expected $N$ merupakan frekuensi harapan, yakni untuk sisi angka dan gambar masing-masing sebanyak 50 kali muncul. Pada kolom Residualmerupakan nilai selisih antara frekuensi pengamatan dan frekuensi harapan.

\section{Tabel 10.17 Tabel 10.18}
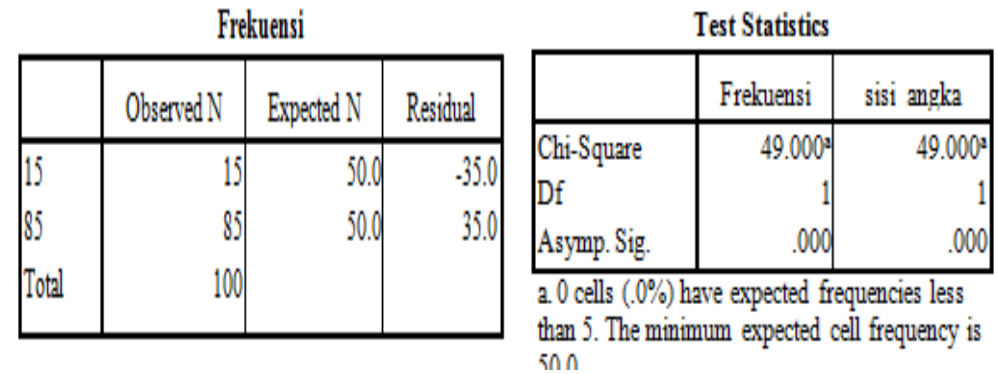

Berdasarkan Tabel 10.18 (Tabel Test Statistics), diketahui nilai statistik dari uji chi-kuadrat atau Chi-Square adalah 49. Diketahui nilai kritis chi-kuadrat $\left(\chi_{\text {kritis }}^{2}\right)$ dengan derajat bebas ( $\mathrm{Df}=$ degree of freedom) 1 dan tingkat signifikansi 5\% adalah 3,841 (silahkan lihat tabel distribusi chi-kuadrat atau cari menggunakan Microsoft Excel). Karena nilai statistik dari uji chi-kuadrat, yakni 49, lebih besar dibandingkan nilai kritis chi-kuadrat, yakni 3,841, maka hipotesis nol ditolak dan hipotesis alternatif diterima. Hal ini berarti proporsi/frekuensi kemunculan sisi angka dan gambar untuk pengamatan berbeda signifikan secara statistik dengan proporsi/frekuensi kemunculan sisi angka dan gambar secara teoritis pada tingkat signifikansi 5\%.Selain itu, pengambilan keputusan terhadap hipotesis juga dapat digunakan nilai Asymp. Sig. atau probabilitas. Diketahui nilai probabilitas adalah 0,000. 
Karena nilai probabilitas lebih kecil dari tingkat signifikansi $\alpha=0,05$, maka hipotesis nol ditolak dan hipotesis alternatif diterima.

\section{PENYELESAIAN DALAM SPSS (CHI-KUADRAT 2)}

Bangun data dalam SPSS seperti Gambar 10.100. Pada variabel adonan, BeriValue 1 untuk Label "tepung", Value 2 untuk Label "susu", Value 3 untuk Label "telur", dan Value 4 untuk Label "gula". Kemudian aktifkan Data View. Input data pada Data Viewseperti pada Gambar 10.100. Pilih Data =>Weight Cases (Gambar 10.101). Kemudian bulatkan Weight cases by.Masukkan variabel proporsi_pengamatan pada kotak Frequency Variable(Gambar 10.102) dan pilih OK. Selanjutnya pilih Analyze $\Rightarrow$ Nonparametric Test $=>$ Chi Square, sehingga muncul kotak dialog Chi Square Test (Gambar 10.103). Masukkan variabel adonan dan proporsi_pengamatan pada kotak Test Variable List. Kemudian aktifkan/bulatkanValues pada Expected Values. Diketahui, harapan untuk adonan yang dihasilkan mengandung 250 gram tepung, $100 \mathrm{ml}$ susu, 100 gram telur, dan 50 gram gula, sehingga pada Values isi 250, kemudian pilih Add. Isi lagi Values 100, kemudian pilih Add, sampai dengan 50. Setelah itu pilih OK. 


\begin{tabular}{|c|c|}
\hline proporsi_pengamatan & adonan \\
\hline 275 & 1 \\
\hline 95 & 2 \\
\hline 70 & 3 \\
\hline 60 & 4 \\
\hline & \\
\hline proporsi_pengamatan & adonan \\
\hline 275 & tepung \\
\hline 95 & susu \\
\hline 70 & telur \\
\hline 60 & gula \\
\hline
\end{tabular}

\section{Gambar 10.100}

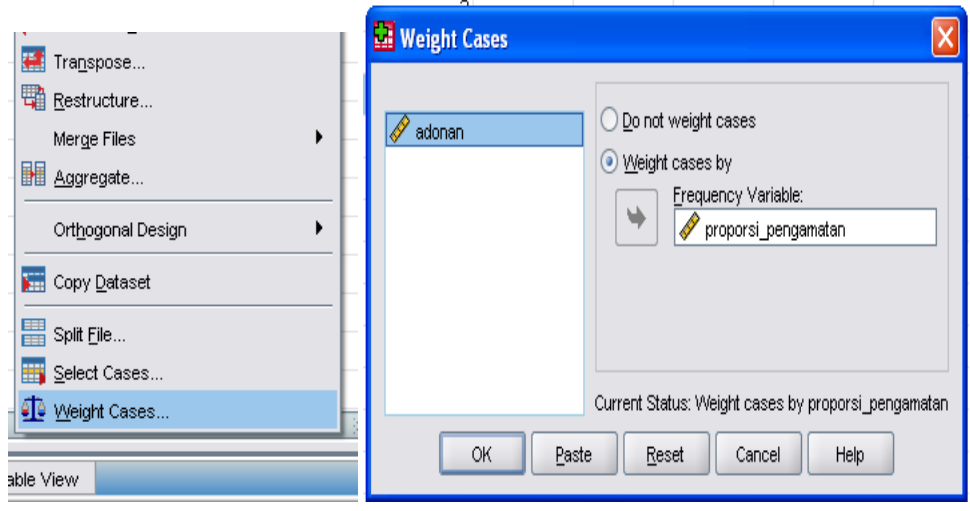

\section{Gambar 10.101}

\section{Gambar 10.102}

Berdasarkan Tabel 10.19 (Tabel adonan), pada kolom Observed $N$ merupakan proporsi adonan pengamatanuntuk tepung, susu, telur, dan gula yang masing-masing 275, 95, 70, dan 60. Kolom Expected Nmerupakan proporsi adonan harapan untuktepung, susu, telur, dan gula yang masing-masing 250, 100, 100, dan 50 .

Pada Tabel 10.20 (Tabel Test Statistics), diketahuinilai statistik dari uji chi-kuadrat atau Chi-Square adalah 13,750. Diketahui nilai kritis chi-kuadrat $\left(\chi_{\text {kritis }}^{2}\right)$ dengan derajat bebas $(\mathrm{Df}=$ degree 
of freedom) 3 dan tingkat signifikansi $1 \%$ adalah 11,345. Oleh karena nilai statistik dari uji chi-kuadrat lebih besar dari nilai kritis chi-kuadrat, maka hipotesis nol ditolak dan hipotesis alternatif diterima. Hal ini berarti proporsi adonan kue yang telah dihasilkan berbeda signifikan secara statistik dengan proporsi adonan kue yang telah ditetapkan pada mesin pencampur adonan kue pada tingkat signifikansi $1 \%$.

Selain itu, pengambilan keputusan terhadap hipotesis juga dapat digunakan nilai Asymp. Sig. atau probabilitas. Diketahui nilai probabilitas adalah 0,003. Karena nilai probabilitas lebih kecil dari tingkat signifikansi $\alpha=0,01$, maka hipotesis nol ditolak dan hipotesis alternatif diterima.

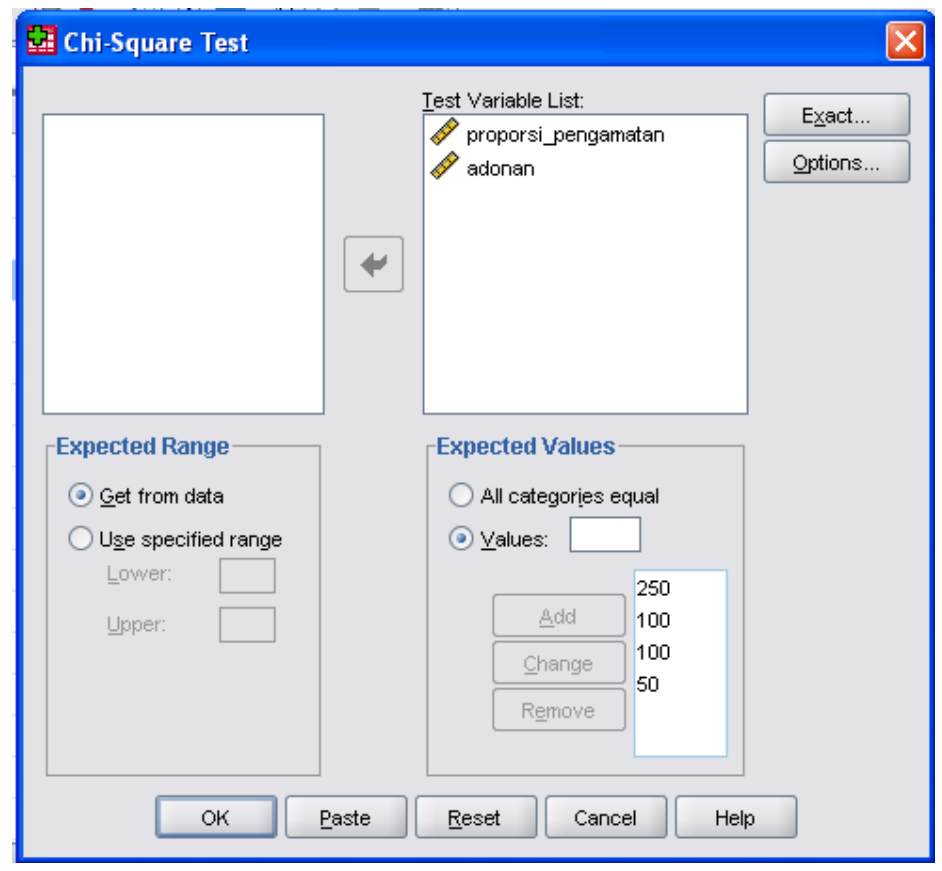

Gambar 10.103 
Tabel 10.19

\begin{tabular}{|l|r|r|r|}
\hline & Adonan \\
\hline & Observed N & Expected N & Residual \\
\hline Tepung & 275 & 250.0 & 25.0 \\
Susu & 95 & 100.0 & -5.0 \\
Telur & 70 & 100.0 & -30.0 \\
Gula & 60 & 50.0 & 10.0 \\
Total & 500 & & \\
\hline
\end{tabular}

Tabel 10.20

\begin{tabular}{|l|r|r|}
\multicolumn{3}{|c}{ Test Statistics } \\
\hline & proporsi_pengamatan & \multicolumn{1}{c|}{ adonan } \\
\hline Chi-Square & $1166.150^{\mathrm{a}}$ & $13.750^{\mathrm{a}}$ \\
Df & 3 & 3 \\
Asymp. Sig. & .000 & .003 \\
\hline
\end{tabular}

a. 0 cells $(.0 \%)$ have expected frequencies less than 5 . The minimum expected cell frequency is 50.0. 


\section{DAFTAR PUSTAKA}

Conover, W. J., 1999, Practical Nonparametric Statistics, $3^{\text {rd }}$ Edition, New York: John Wiley \& Sons, Inc.

Gujarati, D. N., 2003, Basic Econometrics, $4^{\text {th }}$ Edition, New York, NY:

McGraw-Hill Companies.

Mann, P. S., dan Lacke, C. J., 2011, Introductory Statistics: International

Student Version, $7^{\text {th }}$ Edition, Asia: John Wiley \& Son (Asia) Pte. Ltd.

Montgomery, D. C., dan Runger G. C., 2007, Applied Statistics and Probability

for Engineers, $4^{\text {th }}$ Edition, Asia: John Wiley \& Son (Asia) Pte. Ltd.

Sastrosupadi, Adji, 2000, Rancangan Percobaan Praktis Bidang Pertanian,

Yogyakarta: Kanisius.

Siegel, Sidney, 1997, Statistik Nonparametrik Untuk Ilmu-Ilmu Sosial, Cetakan Ketujuh, Jakarta: PT Gramedia Pustaka Utama.

Siregar, Sofyan, 2013, Statistik Parametrik untuk Penelitian Kuantitatif,

Dilengkapi dengan Perhitungan Manual dan Aplikasi SPSS Versi 17, Jakarta: Bumi Aksara.

Smidt, R. K., dan Sanders, D.H., 2000, Statistics A First Course, $6^{\text {th }}$ Edition,

United States of America: McGraw-Hill Companies.

Spiegel, M. R., dan Stephens, J. L., 2007, Schaums Outline Statistik, Edisi

Ketiga, Jakarta: Erlangga.

Sudjana, 2000, Metode Statistika, Edisi Keenam, Bandung: Tarsito.

Suharjo, Bambang, 2008, Analisis Regresi Terapan dengan SPSS, Yogyakarta, Graha Ilmu.

Suharyadi dan Purwanto, S. K., 2009, Statistika untuk Ekonomi dan Keuangan Modern, Edisi Kedua, Jakarta: Salemba Empat.

Supranto, J., 2004, Ekonometri, Buku Kedua, Jakarta: Ghalia Indonesia.

Supranto, J., 2005, Ekonometri, Buku Kesatu, Bogor: Ghalia Indonesia.

Susetyo, Budi, 2010, Statistika untuk Analisis Data Penelitian, Bandung: PT Refika Aditama. 


\section{LAMPIRAN}

\section{Tabel Distribusi Normal Standar}

\begin{tabular}{|c|c|c|c|c|c|c|c|c|c|c|}
\hline$z$ & 0 & 0.01 & 0.02 & 0.03 & 0.04 & 0.05 & 0.06 & 0.07 & 0.08 & 0.09 \\
\hline 0 & 0.0000 & 0.0040 & 0.0080 & 0.0120 & 0.0160 & 0.0199 & 0.0239 & 0.0279 & 0.0319 & 0.0359 \\
\hline 0.1 & 0.0398 & 0.0438 & 0.0478 & 0.0517 & 0.0557 & 0.0596 & 0.0636 & 0.0675 & 0.0714 & 0.0753 \\
\hline 0.2 & 0.0793 & 0.0832 & 0.0871 & 0.0910 & 0.0948 & 0.0987 & 0.1026 & 0.1064 & 0.1103 & 0.1141 \\
\hline 0.3 & 0.1179 & 0.1217 & 0.1255 & 0.1293 & 0.1331 & 0.1368 & 0.1406 & 0.1443 & 0.1480 & 0.1517 \\
\hline 0.4 & 0.1554 & 0.1591 & 0.1628 & 0.1664 & 0.1700 & 0.1736 & 0.1772 & 0.1808 & 0.1844 & 0.1879 \\
\hline 0.5 & 0.1915 & 0.1950 & 0.1985 & 0.2019 & 0.2054 & 0.2088 & 0.2123 & 0.2157 & 0.2190 & 0.2224 \\
\hline 0.6 & 0.2257 & 0.2291 & 0.2324 & 0.2357 & 0.2389 & 0.2422 & 0.2454 & 0.2486 & 0.2517 & 0.2549 \\
\hline 0.7 & 0.2580 & 0.2611 & 0.2642 & 0.2673 & 0.2704 & 0.2734 & 0.2764 & 0.2794 & 0.2823 & 0.2852 \\
\hline 0.8 & 0.2881 & 0.2910 & 0.2939 & 0.2967 & 0.2995 & 0.3023 & 0.3051 & 0.3078 & 0.3106 & 0.3133 \\
\hline 0.9 & 0.3159 & 0.3186 & 0.3212 & 0.3238 & 0.3264 & 0.3289 & 0.3315 & 0.3340 & 0.3365 & 0.3389 \\
\hline 1 & 0.3413 & 0.3438 & 0.3461 & 0.3485 & 0.3508 & 0.3531 & 0.3554 & 0.3577 & 0.3599 & 0.3621 \\
\hline 1.1 & 0.3643 & 0.3665 & 0.3686 & 0.3708 & 0.3729 & 0.3749 & 0.3770 & 0.3790 & 0.3810 & 0.3830 \\
\hline 1.2 & 0.3849 & 0.3869 & 0.3888 & 0.3907 & 0.3925 & 0.3944 & 0.3962 & 0.3980 & 0.3997 & 0.4015 \\
\hline 1.3 & 0.4032 & 0.4049 & 0.4066 & 0.4082 & 0.4099 & 0.4115 & 0.4131 & 0.4147 & 0.4162 & 0.4177 \\
\hline 1.4 & 0.4192 & 0.4207 & 0.4222 & 0.4236 & 0.4251 & 0.4265 & 0.4279 & 0.4292 & 0.4306 & 0.4319 \\
\hline 1.5 & 0.4332 & 0.4345 & 0.4357 & 0.4370 & 0.4382 & 0.4394 & 0.4406 & 0.4418 & 0.4429 & 0.4441 \\
\hline 1.6 & 0.4452 & 0.4463 & 0.4474 & 0.4484 & 0.4495 & 0.4505 & 0.4515 & 0.4525 & 0.4535 & 0.4545 \\
\hline 1.7 & 0.4554 & 0.4564 & 0.4573 & 0.4582 & 0.4591 & 0.4599 & 0.4608 & 0.4616 & 0.4625 & 0.4633 \\
\hline 1.8 & 0.4641 & 0.4649 & 0.4656 & 0.4664 & 0.4671 & 0.4678 & 0.4686 & 0.4693 & 0.4699 & 0.4706 \\
\hline 1.9 & 0.4713 & 0.4719 & 0.4726 & 0.4732 & 0.4738 & 0.4744 & 0.4750 & 0.4756 & 0.4761 & 0.4767 \\
\hline 2 & 0.4772 & 0.4778 & 0.4783 & 0.4788 & 0.4793 & 0.4798 & 0.4803 & 0.4808 & 0.4812 & 0.4817 \\
\hline 2.1 & 0.4821 & 0.4826 & 0.4830 & 0.4834 & 0.4838 & 0.4842 & 0.4846 & 0.4850 & 0.4854 & 0.4857 \\
\hline 2.2 & 0.4861 & 0.4864 & 0.4868 & 0.4871 & 0.4875 & 0.4878 & 0.4881 & 0.4884 & 0.4887 & 0.4890 \\
\hline
\end{tabular}

\section{Tabel Distribusi Normal Standar Kumulatif}

\begin{tabular}{|c|c|c|c|c|c|c|c|c|c|c|}
\hline$z$ & 0,00 & 0,01 & 0,02 & 0,03 & 0,04 & 0,05 & 0,06 & 0,07 & 0,08 & 0,09 \\
\hline-3.6 & 0.0002 & 0.0002 & 0.0001 & 0.0001 & 0.0001 & 0.0001 & 0.0001 & 0.0001 & 0.0001 & 0.0001 \\
\hline-3.5 & 0.0002 & 0.0002 & 0.0002 & 0.0002 & 0.0002 & 0.0002 & 0.0002 & 0.0002 & 0.0002 & 0.0002 \\
\hline-3.4 & 0.0003 & 0.0003 & 0.0003 & 0.0003 & 0.0003 & 0.0003 & 0.0003 & 0.0003 & 0.0003 & 0.0002 \\
\hline-3.3 & 0.0005 & 0.0005 & 0.0005 & 0.0004 & 0.0004 & 0.0004 & 0.0004 & 0.0004 & 0.0004 & 0.0003 \\
\hline-3.2 & 0.0007 & 0.0007 & 0.0006 & 0.0006 & 0.0006 & 0.0006 & 0.0006 & 0.0005 & 0.0005 & 0.0005 \\
\hline-3.1 & 0.0010 & 0.0009 & 0.0009 & 0.0009 & 0.0008 & 0.0008 & 0.0008 & 0.0008 & 0.0007 & 0.0007 \\
\hline-3 & 0.0013 & 0.0013 & 0.0013 & 0.0012 & 0.0012 & 0.0011 & 0.0011 & 0.0011 & 0.0010 & 0.0010 \\
\hline-2.9 & 0.0019 & 0.0018 & 0.0018 & 0.0017 & 0.0016 & 0.0016 & 0.0015 & 0.0015 & 0.0014 & 0.0014 \\
\hline-2.8 & 0.0026 & 0.0025 & 0.0024 & 0.0023 & 0.0023 & 0.0022 & 0.0021 & 0.0021 & 0.0020 & 0.0019 \\
\hline-2.7 & 0.0035 & 0.0034 & 0.0033 & 0.0032 & 0.0031 & 0.0030 & 0.0029 & 0.0028 & 0.0027 & 0.0026 \\
\hline-2.6 & 0.0047 & 0.0045 & 0.0044 & 0.0043 & 0.0041 & 0.0040 & 0.0039 & 0.0038 & 0.0037 & 0.0036 \\
\hline-2.5 & 0.0062 & 0.0060 & 0.0059 & 0.0057 & 0.0055 & 0.0054 & 0.0052 & 0.0051 & 0.0049 & 0.0048 \\
\hline-2.4 & 0.0082 & 0.0080 & 0.0078 & 0.0075 & 0.0073 & 0.0071 & 0.0069 & 0.0068 & 0.0066 & 0.0064 \\
\hline-2.3 & 0.0107 & 0.0104 & 0.0102 & 0.0099 & 0.0096 & 0.0094 & 0.0091 & 0.0089 & 0.0087 & 0.0084 \\
\hline-2.2 & 0.0139 & 0.0136 & 0.0132 & 0.0129 & 0.0125 & 0.0122 & 0.0119 & 0.0116 & 0.0113 & 0.0110 \\
\hline-2.1 & 0.0179 & 0.0174 & 0.0170 & 0.0166 & 0.0162 & 0.0158 & 0.0154 & 0.0150 & 0.0146 & 0.0143 \\
\hline-2 & 0.0228 & 0.0222 & 0.0217 & 0.0212 & 0.0207 & 0.0202 & 0.0197 & 0.0192 & 0.0188 & 0.0183 \\
\hline-1.9 & 0.0287 & 0.0281 & 0.0274 & 0.0268 & 0.0262 & 0.0256 & 0.0250 & 0.0244 & 0.0239 & 0.0233 \\
\hline-1.8 & 0.0359 & 0.0351 & 0.0344 & 0.0336 & 0.0329 & 0.0322 & 0.0314 & 0.0307 & 0.0301 & 0.0294 \\
\hline-1.7 & 0.0446 & 0.0436 & 0.0427 & 0.0418 & 0.0409 & 0.0401 & 0.0392 & 0.0384 & 0.0375 & 0.0367 \\
\hline-1.6 & 0.0548 & 0.0537 & 0.0526 & 0.0516 & 0.0505 & 0.0495 & 0.0485 & 0.0475 & 0.0465 & 0.0455 \\
\hline-1.5 & 0.0668 & 0.0655 & 0.0643 & 0.0630 & 0.0618 & 0.0606 & 0.0594 & 0.0582 & 0.0571 & 0.0559 \\
\hline-1.4 & 0.0808 & 0.0793 & 0.0778 & 0.0764 & 0.0749 & 0.0735 & 0.0721 & 0.0708 & 0.0694 & 0.0681 \\
\hline & & & & & & & & &
\end{tabular}




\begin{tabular}{|c|c|c|c|c|c|c|c|c|c|c|}
\hline-1.3 & 0.0968 & 0.0951 & 0.0934 & 0.0918 & 0.0901 & 0.0885 & 0.0869 & 0.0853 & 0.0838 & 0.0823 \\
\hline-1.2 & 0.1151 & 0.1131 & 0.1112 & 0.1093 & 0.1075 & 0.1056 & 0.1038 & 0.1020 & 0.1003 & 0.0985 \\
\hline-1.1 & 0.1357 & 0.1335 & 0.1314 & 0.1292 & 0.1271 & 0.1251 & 0.1230 & 0.1210 & 0.1190 & 0.1170 \\
\hline-1 & 0.1587 & 0.1562 & 0.1539 & 0.1515 & 0.1492 & 0.1469 & 0.1446 & 0.1423 & 0.1401 & 0.1379 \\
\hline-0.9 & 0.1841 & 0.1814 & 0.1788 & 0.1762 & 0.1736 & 0.1711 & 0.1685 & 0.1660 & 0.1635 & 0.1611 \\
\hline-0.8 & 0.2119 & 0.2090 & 0.2061 & 0.2033 & 0.2005 & 0.1977 & 0.1949 & 0.1922 & 0.1894 & 0.1867 \\
\hline-0.7 & 0.2420 & 0.2389 & 0.2358 & 0.2327 & 0.2296 & 0.2266 & 0.2236 & 0.2206 & 0.2177 & 0.2148 \\
\hline-0.6 & 0.2743 & 0.2709 & 0.2676 & 0.2643 & 0.2611 & 0.2578 & 0.2546 & 0.2514 & 0.2483 & 0.2451 \\
\hline-0.5 & 0.3085 & 0.3050 & 0.3015 & 0.2981 & 0.2946 & 0.2912 & 0.2877 & 0.2843 & 0.2810 & 0.2776 \\
\hline-0.4 & 0.3446 & 0.3409 & 0.3372 & 0.3336 & 0.3300 & 0.3264 & 0.3228 & 0.3192 & 0.3156 & 0.3121 \\
\hline-0.3 & 0.3821 & 0.3783 & 0.3745 & 0.3707 & 0.3669 & 0.3632 & 0.3594 & 0.3557 & 0.3520 & 0.3483 \\
\hline-0.2 & 0.4207 & 0.4168 & 0.4129 & 0.4090 & 0.4052 & 0.4013 & 0.3974 & 0.3936 & 0.3897 & 0.3859 \\
\hline-0.1 & 0.4602 & 0.4562 & 0.4522 & 0.4483 & 0.4443 & 0.4404 & 0.4364 & 0.4325 & 0.4286 & 0.4247 \\
\hline 0 & 0.5000 & 0.5040 & 0.5080 & 0.5120 & 0.5160 & 0.5199 & 0.5239 & 0.5279 & 0.5319 & 0.5359 \\
\hline 0.1 & 0.5398 & 0.5438 & 0.5478 & 0.5517 & 0.5557 & 0.5596 & 0.5636 & 0.5675 & 0.5714 & 0.5753 \\
\hline 0.2 & 0.5793 & 0.5832 & 0.5871 & 0.5910 & 0.5948 & 0.5987 & 0.6026 & 0.6064 & 0.6103 & 0.6141 \\
\hline 0.3 & 0.6179 & 0.6217 & 0.6255 & 0.6293 & 0.6331 & 0.6368 & 0.6406 & 0.6443 & 0.6480 & 0.6517 \\
\hline 0.4 & 0.6554 & 0.6591 & 0.6628 & 0.6664 & 0.6700 & 0.6736 & 0.6772 & 0.6808 & 0.6844 & 0.6879 \\
\hline 0.5 & 0.6915 & 0.6950 & 0.6985 & 0.7019 & 0.7054 & 0.7088 & 0.7123 & 0.7157 & 0.7190 & 0.7224 \\
\hline 0.6 & 0.7257 & 0.7291 & 0.7324 & 0.7357 & 0.7389 & 0.7422 & 0.7454 & 0.7486 & 0.7517 & 0.7549 \\
\hline 0.7 & 0.7580 & 0.7611 & 0.7642 & 0.7673 & 0.7704 & 0.7734 & 0.7764 & 0.7794 & 0.7823 & 0.7852 \\
\hline 0.8 & 0.7881 & 0.7910 & 0.7939 & 0.7967 & 0.7995 & 0.8023 & 0.8051 & 0.8078 & 0.8106 & 0.8133 \\
\hline 0.9 & 0.8159 & 0.8186 & 0.8212 & 0.8238 & 0.8264 & 0.8289 & 0.8315 & 0.8340 & 0.8365 & 0.8389 \\
\hline 1 & 0.8413 & 0.8438 & 0.8461 & 0.8485 & 0.8508 & 0.8531 & 0.8554 & 0.8577 & 0.8599 & 0.8621
\end{tabular}

Tabel Distribusi $t$-Student

\begin{tabular}{|c|c|c|c|c|c|c|}
\hline \multirow{2}{*}{$\begin{array}{c}\text { derajat } \\
\text { bebas }\end{array}$} & \multicolumn{7}{|c|}{ luas sisi (uji satu arah) } \\
\cline { 2 - 7 } & 0.1 & 0.05 & 0.025 & 0.01 & 0.005 & 0.0005 \\
\cline { 2 - 7 } & 0.2 & 0.1 & 0.05 & 0.02 & 0.01 & 0.001 \\
\hline 1 & 3.078 & 6.314 & 12.706 & 31.821 & 63.657 & 636.619 \\
\hline 2 & 1.886 & 2.920 & 4.303 & 6.965 & 9.925 & 31.599 \\
\hline 3 & 1.638 & 2.353 & 3.182 & 4.541 & 5.841 & 12.924 \\
\hline 4 & 1.533 & 2.132 & 2.776 & 3.747 & 4.604 & 8.610 \\
\hline 5 & 1.476 & 2.015 & 2.571 & 3.365 & 4.032 & 6.869 \\
\hline 6 & 1.440 & 1.943 & 2.447 & 3.143 & 3.707 & 5.959 \\
\hline 7 & 1.415 & 1.895 & 2.365 & 2.998 & 3.499 & 5.408 \\
\hline 8 & 1.397 & 1.860 & 2.306 & 2.896 & 3.355 & 5.041 \\
\hline 9 & 1.383 & 1.833 & 2.262 & 2.821 & 3.250 & 4.781 \\
\hline 10 & 1.372 & 1.812 & 2.228 & 2.764 & 3.169 & 4.587 \\
\hline 11 & 1.363 & 1.796 & 2.201 & 2.718 & 3.106 & 4.437 \\
\hline 12 & 1.356 & 1.782 & 2.179 & 2.681 & 3.055 & 4.318 \\
\hline 13 & 1.350 & 1.771 & 2.160 & 2.650 & 3.012 & 4.221 \\
\hline 14 & 1.345 & 1.761 & 2.145 & 2.624 & 2.977 & 4.140 \\
\hline 15 & 1.341 & 1.753 & 2.131 & 2.602 & 2.947 & 4.073 \\
\hline 16 & 1.337 & 1.746 & 2.120 & 2.583 & 2.921 & 4.015 \\
\hline 17 & 1.333 & 1.740 & 2.110 & 2.567 & 2.898 & 3.965 \\
\hline 18 & 1.330 & 1.734 & 2.101 & 2.552 & 2.878 & 3.922 \\
\hline 19 & 1.328 & 1.729 & 2.093 & 2.539 & 2.861 & 3.883 \\
\hline 20 & 1.325 & 1.725 & 2.086 & 2.528 & 2.845 & 3.850 \\
\hline
\end{tabular}




\section{Tabel Distribusi $\boldsymbol{F}$}

\begin{tabular}{|c|c|c|c|c|c|c|}
\hline \multicolumn{7}{|c|}{ luas sisi kanan $0.01, \alpha=0.01$} \\
\hline & derajat bebas pembilang & 1 & 2 & 3 & 4 & 5 \\
\hline derajat bebas penyebut & & & & & & \\
\hline 1 & & 4052.18 & 4999.50 & 5403.35 & 5624.58 & 5763.65 \\
\hline 2 & & 98.50 & 99.00 & 99.17 & 99.25 & 99.30 \\
\hline 3 & & 34.12 & 30.82 & 29.46 & 28.71 & 28.24 \\
\hline 4 & & 21.20 & 18.00 & 16.69 & 15.98 & 15.52 \\
\hline 5 & & 16.26 & 13.27 & 12.06 & 11.39 & 10.97 \\
\hline 6 & & 13.75 & 10.92 & 9.78 & 9.15 & 8.75 \\
\hline 7 & & 12.25 & 9.55 & 8.45 & 7.85 & 7.46 \\
\hline 8 & & 11.26 & 8.65 & 7.59 & 7.01 & 6.63 \\
\hline 9 & & 10.56 & 8.02 & 6.99 & 6.42 & 6.06 \\
\hline 10 & & 10.04 & 7.56 & 6.55 & 5.99 & 5.64 \\
\hline 11 & & 9.65 & 7.21 & 6.22 & 5.67 & 5.32 \\
\hline 12 & & 9.33 & 6.93 & 5.95 & 5.41 & 5.06 \\
\hline 13 & & 9.07 & 6.70 & 5.74 & 5.21 & 4.86 \\
\hline 15 & & 8.86 & 6.51 & 5.56 & 5.04 & 4.69 \\
\hline 16 & & 8.68 & 6.36 & 5.42 & 4.89 & 4.56 \\
\hline 17 & & 8.53 & 6.23 & 5.29 & 4.77 & 4.44 \\
\hline 18 & & 8.40 & 6.11 & 5.18 & 4.67 & 4.34 \\
\hline 19 & & 8.29 & 6.01 & 5.09 & 4.58 & 4.25 \\
\hline 20 & & 8.18 & 5.93 & 5.01 & 4.50 & 4.17 \\
\hline 21 & & 8.10 & 5.85 & 4.94 & 4.43 & 4.10 \\
\hline & & 8.02 & 5.78 & 4.87 & 4.37 & 4.04 \\
\hline
\end{tabular}

\begin{tabular}{|c|c|c|c|c|c|c|}
\hline \multicolumn{9}{|c|}{ luas sisi kanan $0.01, \alpha=0.01$} \\
\hline & derajat bebas pembilang & 6 & 7 & 8 & 9 & 10 \\
\hline derajat bebas penyebut & & & & & & \\
\hline 1 & & 5858.99 & 5928.36 & 5981.07 & 6022.47 & 6055.85 \\
\hline 2 & & 99.33 & 99.36 & 99.37 & 99.39 & 99.40 \\
\hline 3 & & 27.91 & 27.67 & 27.49 & 27.35 & 27.23 \\
\hline 4 & & 15.21 & 14.98 & 14.80 & 14.66 & 14.55 \\
\hline 5 & & 10.67 & 10.46 & 10.29 & 10.16 & 10.05 \\
\hline 6 & & 8.47 & 8.26 & 8.10 & 7.98 & 7.87 \\
\hline 7 & & 7.19 & 6.99 & 6.84 & 6.72 & 6.62 \\
\hline 8 & & 6.37 & 6.18 & 6.03 & 5.91 & 5.81 \\
\hline 9 & & 5.80 & 5.61 & 5.47 & 5.35 & 5.26 \\
\hline 10 & & 5.39 & 5.20 & 5.06 & 4.94 & 4.85 \\
\hline 11 & & 5.07 & 4.89 & 4.74 & 4.63 & 4.54 \\
\hline 12 & & 4.82 & 4.64 & 4.50 & 4.39 & 4.30 \\
\hline 13 & & 4.62 & 4.44 & 4.30 & 4.19 & 4.10 \\
\hline 14 & & 4.46 & 4.28 & 4.14 & 4.03 & 3.94 \\
\hline 15 & & 4.32 & 4.14 & 4.00 & 3.89 & 3.80 \\
\hline 17 & & 4.20 & 4.03 & 3.89 & 3.78 & 3.69 \\
\hline 18 & & 4.10 & 3.93 & 3.79 & 3.68 & 3.59 \\
\hline 19 & & 4.01 & 3.84 & 3.71 & 3.60 & 3.51 \\
\hline 20 & & 3.94 & 3.77 & 3.63 & 3.52 & 3.43 \\
\hline 21 & & 3.87 & 3.70 & 3.56 & 3.46 & 3.37 \\
\hline & & 3.81 & 3.64 & 3.51 & 3.40 & 3.31 \\
\hline
\end{tabular}

\begin{tabular}{|c|c|c|c|c|c|c|}
\hline \multicolumn{9}{|c|}{ luas sisi kanan $0.05, a=0.05$} & \multicolumn{3}{|c|}{$c \mid$} \\
\hline & derajat bebas pembilang & 1 & 2 & 3 & 4 & 5 \\
\hline derajat bebas penyebut & & & & & & \\
\hline 1 & & 161.45 & 199.50 & 215.71 & 224.58 & 230.16 \\
\hline 2 & & 18.51 & 19.00 & 19.16 & 19.25 & 19.30 \\
\hline 3 & & 10.13 & 9.55 & 9.28 & 9.12 & 9.01 \\
\hline 4 & & 7.71 & 6.94 & 6.59 & 6.39 & 6.26 \\
\hline 5 & & 6.61 & 5.79 & 5.41 & 5.19 & 5.05 \\
\hline 6 & & 5.99 & 5.14 & 4.76 & 4.53 & 4.39 \\
\hline 7 & & 5.59 & 4.74 & 4.35 & 4.12 & 3.97 \\
\hline 8 & & 5.32 & 4.46 & 4.07 & 3.84 & 3.69 \\
\hline 9 & & 5.12 & 4.26 & 3.86 & 3.63 & 3.48 \\
\hline 10 & & 4.96 & 4.10 & 3.71 & 3.48 & 3.33 \\
\hline 11 & & 4.84 & 3.98 & 3.59 & 3.36 & 3.20 \\
\hline 12 & & 4.75 & 3.89 & 3.49 & 3.26 & 3.11 \\
\hline 13 & & 4.67 & 3.81 & 3.41 & 3.18 & 3.03 \\
\hline 14 & & 4.60 & 3.74 & 3.34 & 3.11 & 2.96 \\
\hline 15 & & 4.54 & 3.68 & 3.29 & 3.06 & 2.90 \\
\hline 16 & & 4.49 & 3.63 & 3.24 & 3.01 & 2.85 \\
\hline 17 & & 4.45 & 3.59 & 3.20 & 2.96 & 2.81 \\
\hline 18 & & 4.41 & 3.55 & 3.16 & 2.93 & 2.77 \\
\hline 19 & & 4.38 & 3.52 & 3.13 & 2.90 & 2.74 \\
\hline 20 & & 4.35 & 3.49 & 3.10 & 2.87 & 2.71 \\
\hline 21 & & 4.32 & 3.47 & 3.07 & 2.84 & 2.68 \\
\hline
\end{tabular}


luas sisi kanan $0.05, \alpha=0.05$

\begin{tabular}{|c|c|c|c|c|c|c|}
\hline \multicolumn{7}{|c|}{ luas sisi kanan $0.05, \alpha=0.05$} \\
\hline & derajat bebas pembilang & 6 & 7 & 8 & 9 & 10 \\
\hline \multicolumn{7}{|l|}{ derajat bebas penyebut } \\
\hline 1 & & 233.99 & 236.77 & 238.88 & 240.54 & 241.88 \\
\hline 2 & & 19.33 & 19.35 & 19.37 & 19.38 & 19.40 \\
\hline 3 & & 8.94 & 8.89 & 8.85 & 8.81 & 8.79 \\
\hline 4 & & 6.16 & 6.09 & 6.04 & 6.00 & 5.96 \\
\hline 5 & & 4.95 & 4.88 & 4.82 & 4.77 & 4.74 \\
\hline 6 & & 4.28 & 4.21 & 4.15 & 4.10 & 4.06 \\
\hline 7 & & 3.87 & 3.79 & 3.73 & 3.68 & 3.64 \\
\hline 8 & & 3.58 & 3.50 & 3.44 & 3.39 & 3.35 \\
\hline 9 & & 3.37 & 3.29 & 3.23 & 3.18 & 3.14 \\
\hline 10 & & 3.22 & 3.14 & 3.07 & 3.02 & 2.98 \\
\hline 11 & & 3.09 & 3.01 & 2.95 & 2.90 & 2.85 \\
\hline 12 & & 3.00 & 2.91 & 2.85 & 2.80 & 2.75 \\
\hline 13 & & 2.92 & 2.83 & 2.77 & 2.71 & 2.67 \\
\hline 14 & & 2.85 & 2.76 & 2.70 & 2.65 & 2.60 \\
\hline 15 & & 2.79 & 2.71 & 2.64 & 2.59 & 2.54 \\
\hline 16 & & 2.74 & 2.66 & 2.59 & 2.54 & 2.49 \\
\hline 17 & & 2.70 & 2.61 & 2.55 & 2.49 & 2.45 \\
\hline 18 & & 2.66 & 2.58 & 2.51 & 2.46 & 2.41 \\
\hline 19 & & 2.63 & 2.54 & 2.48 & 2.42 & 2.38 \\
\hline 20 & & 2.60 & 2.51 & 2.45 & 2.39 & 2.35 \\
\hline 21 & & 2.57 & 2.49 & 2.42 & 2.37 & 2.32 \\
\hline
\end{tabular}

Tabel Distribusi Chi-Kuadrat

\begin{tabular}{|c|c|c|c|c|}
\hline \multirow{2}{*}{ derajat bebas } & \multicolumn{4}{|c|}{ luas sisi kanan } \\
\cline { 2 - 5 } & 0.1 & 0.05 & 0.02 & 0.01 \\
\hline 1 & 2.706 & 3.841 & 5.412 & 6.635 \\
\hline 2 & 4.605 & 5.991 & 7.824 & 9.210 \\
\hline 3 & 6.251 & 7.815 & 9.837 & 11.345 \\
\hline 4 & 7.779 & 9.488 & 11.668 & 13.277 \\
\hline 5 & 9.236 & 11.070 & 13.388 & 15.086 \\
\hline 6 & 10.645 & 12.592 & 15.033 & 16.812 \\
\hline 7 & 12.017 & 14.067 & 16.622 & 18.475 \\
\hline 8 & 13.362 & 15.507 & 18.168 & 20.090 \\
\hline 9 & 14.684 & 16.919 & 19.679 & 21.666 \\
\hline 10 & 15.987 & 18.307 & 21.161 & 23.209 \\
\hline 11 & 17.275 & 19.675 & 22.618 & 24.725 \\
\hline 12 & 18.549 & 21.026 & 24.054 & 26.217 \\
\hline 13 & 19.812 & 22.362 & 25.472 & 27.688 \\
\hline 14 & 21.064 & 23.685 & 26.873 & 29.141 \\
\hline 15 & 22.307 & 24.996 & 28.259 & 30.578 \\
\hline 16 & 23.542 & 26.296 & 29.633 & 32.000 \\
\hline 17 & 24.769 & 27.587 & 30.995 & 33.409 \\
\hline 18 & 25.989 & 28.869 & 32.346 & 34.805 \\
\hline 19 & 27.204 & 30.144 & 33.687 & 36.191 \\
\hline 20 & 28.412 & 31.410 & 35.020 & 37.566 \\
\hline 21 & 29.615 & 32.671 & 36.343 & 38.932 \\
\hline 22 & 30.813 & 33.924 & 37.659 & 40.289
\end{tabular}




\section{Tabel Distribusi Wilcoxon}

\begin{tabular}{|c|c|c|c|c|}
\hline \multicolumn{5}{|c|}{ pengujian hipotesis dua arah } \\
\hline jumlah elemen dalam sampel & $\alpha=0.005$ & $\alpha=0.01$ & $\alpha=0.025$ & $\alpha=0.05$ \\
\hline 1 & & & & \\
\hline 2 & & & & \\
\hline 3 & & & & \\
\hline 4 & & & & \\
\hline 5 & & & & 1 \\
\hline 6 & & & 1 & 2 \\
\hline 7 & & & 2 & 4 \\
\hline 8 & & 2 & 4 & 6 \\
\hline 9 & 2 & 3 & 6 & 8 \\
\hline 10 & 3 & 5 & 8 & 11 \\
\hline 11 & 5 & 7 & 11 & 14 \\
\hline 12 & 7 & 10 & 14 & 17 \\
\hline 13 & 10 & 13 & 17 & 21 \\
\hline 14 & 13 & 16 & 21 & 26 \\
\hline 15 & 16 & 20 & 25 & 30 \\
\hline 16 & 19 & 24 & 30 & 36 \\
\hline 17 & 23 & 28 & 35 & 41 \\
\hline 18 & 28 & 33 & 40 & 47 \\
\hline 19 & 32 & 38 & 46 & 54 \\
\hline 20 & 37 & 43 & 52 & 60 \\
\hline 21 & 43 & 49 & 59 & 68 \\
\hline 22 & 49 & 56 & 66 & 75 \\
\hline 23 & 55 & 62 & 73 & 83 \\
\hline 24 & 61 & 69 & 81 & 92 \\
\hline 25 & 68 & 77 & 90 & 101 \\
\hline 26 & 76 & 85 & 98 & 110 \\
\hline 27 & 84 & 93 & 107 & 120 \\
\hline 28 & 92 & 102 & 117 & 130 \\
\hline 29 & 100 & 111 & 127 & 141 \\
\hline 30 & 109 & 120 & 137 & 152 \\
\hline
\end{tabular}

\section{Tabel Distribusi Mann-Whitney}

\begin{tabular}{|c|c|c|c|c|c|c|c|c|c|c|c|c|c|c|c|c|c|c|c|c|c|}
\hline \multicolumn{22}{|c|}{ pengujian satu arah $\alpha=0.05$, pengujian dua arah $\alpha=\frac{0.05}{2}=0.025$} \\
\hline \multirow[b]{2}{*}{$n_{1}$} & \multicolumn{21}{|c|}{$n_{2}$} \\
\hline & 1 & 2 & 3 & 4 & 5 & 6 & 7 & 8 & 9 & 10 & 1. & & & 13 & 14 & 15 & 16 & 17 & 18 & 19 & 20 \\
\hline 1 & - & - & - & - & - & - & - & - & - & - & - & & & - & - & - & - & - & - & - & - \\
\hline 2 & - & - & - & - & - & - & - & 0 & 0 & 0 & 0 & & & 1 & 1 & 1 & 1 & 2 & 2 & 2 & 2 \\
\hline 3 & - & - & - & - & 0 & 1 & 1 & 2 & 2 & 3 & 3 & & & 4 & 5 & 5 & 6 & 6 & 7 & 7 & 8 \\
\hline 4 & - & - & - & 0 & 1 & 2 & 3 & 4 & 4 & 5 & 6 & & & 8 & 9 & 10 & 11 & 11 & 12 & 13 & 13 \\
\hline 5 & - & - & 0 & 1 & 2 & 3 & 5 & 6 & 7 & 8 & 9 & & & 12 & 13 & 14 & 15 & 17 & 18 & 19 & 20 \\
\hline 6 & - & - & 1 & 2 & 3 & 5 & 6 & 8 & 10 & 1 & 1 & & & 16 & 17 & 19 & 21 & 22 & 24 & 25 & 27 \\
\hline 7 & - & - & 1 & 3 & 5 & 6 & 8 & 10 & 12 & 1 & 1 & & & 20 & 22 & 24 & 26 & 28 & 30 & 32 & 34 \\
\hline 8 & - & 0 & 2 & 4 & 6 & 8 & 10 & 13 & 15 & 1 & 1 & & & 24 & 26 & 29 & 31 & 34 & 36 & 38 & 41 \\
\hline 9 & - & 0 & 2 & 4 & 7 & 10 & 12 & 15 & 17 & 2 & 2 & & & 28 & 31 & 34 & 37 & 39 & 42 & 45 & 48 \\
\hline 10 & - & 0 & 3 & 5 & 8 & 11 & 14 & 17 & 20 & 23 & 2 & & & 33 & 36 & 39 & 42 & 45 & 48 & 52 & 55 \\
\hline 11 & - & 0 & 3 & 6 & 9 & 13 & 16 & 19 & 23 & 20 & 3 & & & 37 & 40 & 44 & 47 & 51 & 55 & 58 & 62 \\
\hline 12 & - & 1 & 4 & 7 & 11 & 14 & 18 & 22 & 26 & 29 & 3 & & & 41 & 45 & 49 & 53 & 57 & 61 & 65 & 69 \\
\hline 13 & - & 1 & 4 & 8 & 12 & 16 & 20 & 24 & 28 & 33 & 3 & & & 45 & 50 & 54 & 59 & 63 & 67 & 72 & 76 \\
\hline 14 & - & 1 & 5 & 9 & 13 & 17 & 22 & 26 & 31 & 30 & 4 & & & 50 & 55 & 59 & 64 & 67 & 74 & 78 & 83 \\
\hline 15 & - & 1 & 5 & 10 & 14 & 19 & 24 & 29 & 34 & 39 & 4 & & & 54 & 59 & 64 & 70 & 75 & 80 & 85 & 90 \\
\hline 16 & - & 1 & 6 & 11 & 15 & 21 & 26 & 31 & 37 & 47 & 4 & & & 59 & 64 & 70 & 75 & 81 & 86 & 92 & 98 \\
\hline 17 & - & 2 & 6 & 11 & 17 & 22 & 28 & 34 & 39 & 4 & 5 & & & 63 & 67 & 75 & 81 & 87 & 93 & 99 & 105 \\
\hline 18 & - & 2 & 7 & 12 & 18 & 24 & 30 & 36 & 42 & 48 & 5 & & & 67 & 74 & 80 & 86 & 93 & 99 & 106 & 112 \\
\hline 19 & - & 2 & 7 & 13 & 19 & 25 & 32 & 38 & 45 & 5 & 58 & & & 72 & 78 & 85 & 92 & 99 & 106 & 113 & 119 \\
\hline 20 & - & 2 & 8 & 14 & 20 & 27 & 34 & 41 & 48 & 5 & 6 & & & 76 & 83 & 90 & 98 & 105 & 112 & 119 & 127 \\
\hline
\end{tabular}




\begin{tabular}{|c|c|c|c|c|c|c|c|c|c|c|c|c|c|c|c|c|c|c|c|c|}
\hline \multicolumn{11}{|c|}{ pengujian satu arah $\alpha=0.01$, pengujian dua arah $\alpha=\frac{0.01}{2}=0.005$} \\
\hline \multirow{2}{*}{$n_{1}$} & 1 & 2 & 3 & 4 & 5 & 6 & 7 & 8 & 9 & 10 & 11 & 12 & 13 & 14 & 15 & 16 & 17 & 18 & 19 & 20 \\
\hline 1 & - & - & - & - & - & - & - & - & - & - & - & - & - & - & - & - & - & - & - & - \\
\hline 2 & - & - & - & - & - & - & - & - & - & - & - & - & - & - & - & - & - & - & 0 & 0 \\
\hline 3 & - & - & - & - & - & - & - & - & 0 & 0 & 0 & 1 & 1 & 1 & 2 & 2 & 2 & 2 & 3 & 3 \\
\hline 4 & - & - & - & 0 & 0 & 1 & 1 & 2 & 2 & 3 & 3 & 4 & 5 & 5 & 6 & 6 & 7 & 8 & & \\
\hline 5 & - & - & - & 0 & 1 & 1 & 2 & 3 & 4 & 5 & 6 & 7 & 7 & 8 & 9 & 10 & 11 & 12 & 13 & \\
\hline 6 & - & - & - & 0 & 1 & 2 & 3 & 4 & 5 & 6 & 7 & 9 & 10 & 11 & 12 & 13 & 15 & 16 & 17 & 18 \\
\hline 7 & - & - & - & 0 & 1 & 3 & 4 & 6 & 7 & 9 & 10 & 12 & 13 & 15 & 16 & 18 & 19 & 21 & 22 & 24 \\
\hline 8 & - & - & - & 1 & 2 & 4 & 6 & 7 & 9 & 11 & 13 & 15 & 17 & 18 & 20 & 22 & 24 & 26 & 28 & 30 \\
\hline 9 & - & - & 0 & 1 & 3 & 5 & 7 & 9 & 11 & 13 & 16 & 18 & 20 & 22 & 24 & 27 & 29 & 31 & 33 & 36 \\
\hline 10 & - & - & 0 & 2 & 4 & 6 & 9 & 11 & 13 & 16 & 18 & 21 & 24 & 26 & 29 & 31 & 34 & 37 & 39 & 42 \\
\hline 11 & - & - & 0 & 2 & 5 & 7 & 10 & 13 & 16 & 18 & 21 & 24 & 27 & 30 & 33 & 36 & 39 & 42 & 45 & 46 \\
\hline 12 & - & - & 1 & 3 & 6 & 9 & 12 & 15 & 18 & 21 & 24 & 27 & 31 & 34 & 37 & 41 & 44 & 47 & 51 & 54 \\
\hline 13 & - & - & 1 & 3 & 7 & 10 & 13 & 17 & 20 & 24 & 27 & 31 & 34 & 38 & 42 & 45 & 49 & 53 & 56 & 60 \\
\hline 14 & - & - & 1 & 4 & 7 & 11 & 15 & 18 & 22 & 26 & 30 & 34 & 38 & 42 & 46 & 50 & 54 & 58 & 63 & 67 \\
\hline 15 & - & - & 2 & 5 & 8 & 12 & 16 & 20 & 24 & 29 & 33 & 37 & 42 & 46 & 51 & 55 & 60 & 64 & 69 & 73 \\
\hline 16 & - & - & 2 & 5 & 9 & 13 & 18 & 22 & 27 & 31 & 36 & 41 & 45 & 50 & 55 & 60 & 65 & 70 & 74 & 79 \\
\hline 17 & - & - & 2 & 6 & 10 & 15 & 19 & 24 & 29 & 34 & 39 & 44 & 49 & 54 & 60 & 65 & 70 & 75 & 81 & 86 \\
\hline 18 & - & - & 2 & 6 & 11 & 16 & 21 & 26 & 31 & 37 & 42 & 47 & 53 & 58 & 64 & 70 & 75 & 81 & 87 & 92 \\
\hline 19 & - & 0 & 3 & 7 & 12 & 17 & 22 & 28 & 33 & 39 & 45 & 51 & 56 & 63 & 69 & 74 & 81 & 87 & 93 & 99 \\
\hline 20 & - & 0 & 3 & 8 & 13 & 18 & 24 & 30 & 36 & 42 & 46 & 54 & 60 & 67 & 73 & 79 & 86 & 92 & 99 & 105 \\
\hline
\end{tabular}

\section{Tabel Distribusi Kolmogorov-Smirnov}

\begin{tabular}{|c|c|c|c|c|c|}
\hline$n$ & $\alpha=0,2$ & $\alpha=0,1$ & $\alpha=0,05$ & $\alpha=0,02$ & $\alpha=0,01$ \\
\hline 1 & 0,900 & 0,950 & 0,975 & 0,990 & 0,995 \\
\hline 2 & 0,684 & 0,776 & 0,842 & 0,900 & 0,929 \\
\hline 3 & 0,565 & 0,636 & 0,708 & 0,785 & 0,829 \\
\hline 4 & 0,493 & 0,565 & 0,624 & 0,689 & 0,734 \\
\hline 5 & 0,447 & 0,509 & 0,563 & 0,627 & 0,669 \\
\hline 6 & 0,410 & 0,468 & 0,519 & 0,577 & 0,617 \\
\hline 7 & 0,381 & 0,436 & 0,483 & 0,538 & 0,576 \\
\hline 8 & 0,359 & 0,410 & 0,454 & 0,507 & 0,542 \\
\hline 9 & 0,339 & 0,387 & 0,430 & 0,480 & 0,513 \\
\hline 10 & 0,323 & 0,369 & 0,409 & 0,457 & 0,486 \\
\hline 11 & 0,308 & 0,352 & 0,391 & 0,437 & 0,468 \\
\hline 12 & 0,296 & 0,338 & 0,375 & 0,419 & 0,449 \\
\hline 13 & 0,285 & 0,325 & 0,361 & 0,404 & 0,432 \\
\hline 14 & 0,275 & 0,314 & 0,349 & 0,390 & 0,418 \\
\hline 15 & 0,266 & 0,304 & 0,338 & 0,377 & 0,404 \\
\hline 16 & 0,258 & 0,295 & 0,327 & 0,366 & 0,392 \\
\hline 17 & 0,250 & 0,286 & 0,318 & 0,355 & 0,381 \\
\hline 18 & 0,244 & 0,279 & 0,309 & 0,346 & 0,371 \\
\hline 19 & 0,237 & 0,271 & 0,301 & 0,337 & 0,361 \\
\hline 20 & 0,232 & 0,265 & 0,294 & 0,329 & 0,352 \\
\hline 21 & 0,226 & 0,259 & 0,287 & 0,321 & 0,344 \\
\hline 22 & 0,221 & 0,253 & 0,281 & 0,314 & 0,337 \\
\hline 23 & 0,216 & 0,247 & 0,275 & 0,307 & 0,330 \\
\hline 24 & 0,212 & 0,242 & 0,269 & 0,301 & 0,323 \\
\hline 25 & 0,208 & 0,238 & 0,264 & 0,295 & 0,317 \\
\hline
\end{tabular}

